Published in final edited form as:

Adv Cancer Res. 2014 ; 121: 67-124. doi:10.1016/B978-0-12-800249-0.00002-0.

\title{
THERAPEUTIC CANCER VACCINES
}

\author{
Jeffrey Schlom, James W. Hodge, Claudia Palena, Kwong-Yok Tsang, Caroline Jochems, \\ John W. Greiner, Benedetto Farsaci, Ravi A. Madan, Christopher R. Heery, and James L. \\ Gulley \\ Laboratory of Tumor Immunology and Biology, Center for Cancer Research, National Cancer \\ Institute, National Institutes of Health
}

\begin{abstract}
Therapeutic cancer vaccines have the potential of being integrated in the therapy of numerous cancer types and stages. The wide spectrum of vaccine platforms and vaccine targets is reviewed along with the potential for development of vaccines to target cancer cell "stemness," the epithelial-to-mesenchymal transition (EMT) phenotype, and drug resistant populations. Preclinical and recent clinical studies are now revealing how vaccines can optimally be used with other immune-based therapies such as checkpoint inhibitors, and so-called "non-immune"-based therapeutics, radiation, hormonal therapy, and certain small molecule targeted therapies; it is now being revealed that many of these traditional therapies can lyse tumor cells in a manner as to further potentiate the host immune response, alter the phenotype of non-lysed tumor cells to render them more susceptible to T-cell lysis, and/or shift the balance of effector:regulatory cells in a manner to enhance vaccine efficacy. The importance of the tumor microenvironment, the appropriate patient population, and clinical trial endpoints are also discussed in the context of optimizing patient benefit from vaccine-mediate therapy.
\end{abstract}

\section{Keywords}

Cancer vaccines; Immunotherapy; Clinical trials; Animal models; T cells; Prostate cancer; Tumor antigens

\section{INTRODUCTION}

This chapter will encompass the numerous factors involved in the design, development and clinical application of therapeutic cancer vaccines both as a monotherapy and in combination with other forms of immunotherapy, as well as with non-immune-based therapies. Among the topics discussed are (a) the wide spectrum of cancer vaccine targets; (b) the pros and cons of different vaccine platforms; (c) how animal models can be used, and should not be used, in vaccine development; (d) the influence of the tumor microenvironment and regulatory entities on vaccine efficacy; (e) how vaccine combination therapies with certain chemotherapeutic agents, radiation, hormone therapy, and small

Corresponding author: Jeffrey Schlom, Laboratory of Tumor Immunology and Biology, Center for Cancer Research, National Cancer Institute, National Institutes of Health, 10 Center Drive, Room 8B09, Bethesda, MD 20892. TEL: 301-496-4343; js141c@nih.gov. 
molecule targeted therapies and other immune therapeutics can potentially be used to enhance vaccine efficacy; (f) the appropriate patient populations and trial endpoints in vaccine clinical studies and the importance of tumor growth kinetics; and (g) the potential of new vaccines that can target cancer cell "stemness," the epithelial-to-mesenchymal transition (EMT) phenotype, and drug resistance. While this article presents an overview of several aspects of therapeutic cancer vaccine development, many of the examples given are based on preclinical and clinical studies carried out at the National Cancer Institute, National Institutes of Health. Much of the information has been presented in previous review articles (Palena et al., 2013; Schlom et al., 2012; Schlom et al., 2013a; Schlom et al., 2013b) and/or in peer reviewed publications as cited.

\section{CANCER VACCINE TARGETS}

The validity of a target for a therapeutic cancer vaccine will depend on the ability of a tumor cell to process the tumor-associated antigen (TAA) expressed by the vaccine in the context of a peptide-major histocompatibility complex (MHC) for T-cell recognition or on the surface of the tumor cell for B-cell recognition. The level of expression of the TAA in the tumor, the relative specificity of the TAA for tumor vs. normal adult tissue, and the degree of inherent "tolerance" to the given TAA (Cheever et al., 2009; Gulley et al., 2010a) are also of extreme importance. Common targets include oncofetal antigens, oncoproteins, differentiation-associated proteins, and viral proteins, among others (Table 1). The potential ideal target is a somatic point mutation that initiates and/or drives the neoplastic process. Clinical trials are underway to evaluate vaccines that target the various ras mutations found in colorectal and pancreatic cancer. However, large numbers of tumor-associated mutations among the various exons of the p53 suppressor gene, for example, make generating the large number of possible mutant p53 vaccines somewhat prohibitive. Similarly, it is also logistically difficult to develop vaccines to target the wide array of frameshift mutations and unique mutations that occur in individual tumors, and which may differ among different tumor masses of the same patient. On the other hand, vaccines to non-mutated oncoproteins can more easily be developed as targets; they include overexpressed HER2/neu (ERBB2), $\mathrm{p} 53$, and the C-terminal transmembrane subunit of mucin-1 (MUC-1), i.e., MUC1-C (Kufe et al., 2009; Raina et al., 2011).

Numerous trials have targeted "tissue lineage" antigens that are overexpressed in tumors and normally expressed in a non-vital organ, such as prostatic acid phosphatase (PAP), prostatespecific antigen (PSA), and the melanoma-associated antigens glycoprotein 100 (gp100) and tyrosinase. Numerous vaccine trials have also targeted a class of antigens categorized as oncofetal antigens, such as carcinoembryonic antigen (CEA), underglycosylated MUC-1, tumor-associated glycopeptides (Gilewski et al., 2007; Marshall et al., 2000; Ragupathi et al., 2009), and "cancer-testis" antigens defined by serological expression cloning (SEREX) immunodetection such as melanoma-associated antigen (MAGE-A3) and B melanoma antigen (BAGE) (Gnjatic et al., 2009a; Gnjatic et al., 2010; Gnjatic et al., 2009b; Karbach et al., 2011). These antigens are overexpressed in many tumor types and to a lesser extent in some normal adult tissues. The recent approval by the U.S. Food and Drug Administration (FDA) of the Gardasil vaccine targeting the human papillomavirus (HPV) for the prevention of cervical cancer also renders HPV an attractive target for cervical cancer therapy, as does 
targeting the hepatitis $\mathrm{C}$ virus for liver cancer therapy. Preclinical studies have also shown the potential of vaccines that target molecules involved in tumor angiogenesis, such as the vascular endothelial growth factor receptor (VEGF-R) (Kaplan et al., 2006; Xiang et al., 2008).

The most provocative group of potential targets for vaccine therapy are molecules that are associated with cancer "stem cells" and/or the EMT process, both of which are associated with drug resistance (Table 1). Transcription factors that are drivers of EMT are also associated with tumor cell dissemination to the metastatic site. Recent studies have described the plasticity of so-called "cancer stem cells" and the similarities between human carcinoma cells undergoing EMT and the acquisition of "stem-like" characteristics (Polyak et al., 2009).

EMT and cancer "stemness" are associated with the proteins (sex determining region Y)box-2 (SOX-2) and octamer-binding transcription factor 4 (OCT-4) and with carcinoma cells that are CD44 ${ }^{\text {high }}$ and CD24 ${ }^{\text {low }}$ and/or are CD133+ (Dhodapkar, K. M. et al., 2010;

Dhodapkar, M. V. et al., 2011; Hua et al., 2011 Apr 11 [Epub]; Mine et al., 2009; Spisek et al., 2007). Each of these gene products is currently being evaluated for immunogenicity in terms of generating human T-cell responses in vitro, but some also have a relatively broad range of expression in normal adult tissues. The T-box transcription factor Brachyury has recently been identified as a major driver of EMT (Fernando et al., 2010). It has been shown to be selectively expressed on both primary and metastatic lesions of several carcinoma types. T-cell epitopes have been identified on the Brachyury protein that have the ability to generate human $\mathrm{T}$ cells capable of lysing a range of human carcinoma cells (Palena et al., 2007). This will be discussed in detail below.

A potent means to enhance immunogenicity of a self-antigen is by altering specific amino acids of TAAs to develop enhancer agonist epitopes, which are designed to enhance binding either to the MHC or to the T-cell receptor, resulting in higher levels of T-cell responses and/or higher avidity T cells (Dzutsev et al., 2007; Hodge et al., 2005). For example, the gp100 melanoma vaccine contains an enhancer agonist epitope; the PROSTVAC vaccine contains a PSA enhancer agonist epitope, and the PANVAC vaccine contains enhancer agonist epitopes for both CEA and MUC-1. These vaccines will be discussed in more detail below. It is important to note, however, that the $\mathrm{T}$ cells generated by agonist epitopes must be shown to lyse human tumor cells that express the corresponding endogenous native epitope.

\section{SPECTRUM OF CURRENT THERAPEUTIC CANCER VACCINE PLATFORMS}

Each of the 14 platforms in Table 2 has strengths and weaknesses; clinical benefit with the use of the platform can be influenced by the particular TAA that is targeted, the disease and disease stage that is targeted, the clinical trial endpoint, and whether the vaccine is evaluated in combination with an immune stimulant, an inhibitor of immune suppression, or another mode of cancer therapy. Many diverse vaccine platforms have now been evaluated in Phase II and/or Phase III clinical trials, including the use of peptides or proteins in adjuvant, 
recombinant viruses, bacteria or yeast, whole tumor cells, or delivery of protein- or peptideactivated dendritic cells (DCs) (Table 2).

DCs are the most potent antigen-presenting cells (APCs), (Banchereau et al., 2001).

Numerous Phase II studies have now evaluated the use of peptide- or protein-pulsed, or viral vector-infected DCs to treat patients with prostate cancer, colorectal cancer, melanoma, glioma, and other cancers (Table 2), (Okada et al., 2011; Wheeler et al., 2011). The Sipuleucel-T vaccine (Kantoff et al., 2010a) which was recently approved by the FDA for the therapy of minimally symptomatic metastatic castrate-resistant prostate cancer (mCRPC), consists of APCs from peripheral blood mononuclear cells (PBMCs) that have been incubated with the prostate antigen PAP fused to granulocyte macrophage colonystimulating factor (GM-CSF). This vaccine regimen consists of leukaphereses to purify PBMCs from the patient and processing in a central facility where the PAP fusion protein is added to the APCs; these cells are then reinfused to the patient for the purpose of conferring immunity; this process is repeated three times at biweekly intervals. One drawback of DC and/or APC platforms is that they require leukapheresis(es) and cell culture processing of PBMCs, and thus a limited number of vaccinations can be used.

Vaccines based on peptides from TAAs, which are usually administered in an adjuvant and/or with an immune modulator, are generally cost-effective and have the advantage that the investigator knows exactly which epitope to evaluate in terms of patients' immune responses (Disis et al., 2009). However, they also have a potential drawback because they target only one epitope or a few epitopes of the TAA. It is generally believed that for a cancer vaccine to be optimally efficacious, it must induce antigen-specific $\mathrm{CD} 8^{+}$cytotoxic $\mathrm{T}$ cells (CTLs), which are responsible for tumor cell lysis, and antigen-specific CD4+ "helper" $\mathrm{T}$ cells, which provide cytokines to enhance CTL activity. Protein-based vaccines are more costly than peptide-based vaccines, but they usually also contain both CD4 and CD8 epitopes. Many peptide- and protein-based vaccines are used as part of a DC vaccine platform.

Numerous clinical trials are ongoing involving recombinant poxviridae vaccines (Table 3). They include the use of recombinant vaccinia, modified vaccinia strain Ankara (MVA), and the avipoxviruses (fowlpox and canarypox). Poxviruses have the ability to accept large inserts of foreign DNA, and thus can accommodate multiple genes each on individual poxviral promoters. Intracellular expression of the transgene(s) allows for processing of the tumor antigen by both the class I and class II MHC pathways (Moss et al., 1996). Because poxvirus replication and transcription are restricted to the cytoplasm, there is minimal risk to the patient (or host) of insertional mutagenesis. It has been shown in preclinical studies that when the transgene for a TAA is inserted in vaccinia or MVA, it becomes more immunogenic, most likely because of the Toll-like receptors (TLRs) and other properties of the virus that induce a local inflammatory response. This same property of vaccinia, however, leads to virus neutralization by the host immune response and limits their use to one, or at most two, vaccination(s). Recombinant avipoxviruses can be used multiple times; they will induce antiviral immune responses, but they are not neutralizing because their "late" viral coat proteins are not produced in mammalian cells (Hodge et al., 2009; Hodge et al., 2003b; Marshall et al., 2000). 
Other viruses are also being evaluated as vectors for TAAs. Alphaviruses such as Venezuelan Equine Encephalitis (VEE) virus are attractive vectors because, once they have infected the host, they replicate RNA in the cytoplasm and express high levels of a transgene (MacDonald et al., 2000). Recombinant adenovirus vectors are easy to engineer and have shown utility as vaccines and gene therapy agents (Okur et al., $2011 \mathrm{Jul}$ 12), but clinical evaluation has been hindered by high levels of preexisting antiviral immunity. Newer variants of adenoviruses, however, have been developed and evaluated in preclinical studies and clinical trials and appear to be less immunogenic (Morse et al., 2013a; Osada et al., 2009)

Bacteria and yeast have shown some promise as vaccine vectors in preclinical studies and are also being evaluated in clinical trials. Heat-killed recombinant Saccharomyces cerevisiae is inherently non-pathogenic, can be easily propagated and purified, and is very stable. Recombinant yeasts have been shown to activate maturation of human DCs and to present both class I and class II epitopes of transgenes (Remondo et al., 2009; Wansley et al., 2008). Surprisingly, it appears that these vectors can be administered multiple times without eliciting host-neutralizing activity (Wansley et al., 2008). Attenuated recombinant Listeria monocytogenes $(\mathrm{Lm})$ bacteria have also been shown to target DCs, and, like viral and yeast vectors, they stimulate both innate and adaptive immune responses (Singh et al., 2006). Although DNA vaccine platforms have shown promise in preclinical studies (Kaplan, et al., 2006; Xiang, et al., 2008) early clinical trials have been disappointing. Their exact mode of action is not known at this time. However, new constructs and methods of administration may enhance their utility.

The use of whole tumor-cell vaccines has the advantage of presenting the patient's immune system with a range of both known and undefined TAAs as immunogens. However, this same property also potentially diminishes the relative level of expression of a particular TAA or group of TAAs and their presentation and processing by APCs. The use of a killed whole tumor-cell vaccine is usually accompanied by an immune stimulant such as GM-CSF, or Bacillus Calmette-Guerin adjuvant (BCG). Autologous tumor cell vaccines have the advantage of presenting to the immune system the unique set of TAAs, such as particular point mutations or fusion gene products, from a given patient's own tumor (Hoover et al., 1993). Because this technology depends on the availability of tumor biopsies, it is feasible for few tumor types and stages. In one promising variation of this technique, however, DCs and autologous tumor cells are fused together before immunization of the patient (Avigan et al., 2004). DC-tumor cell fusions combine the unique properties of whole tumor-cell vaccines with the enhanced antigen-presenting power of DCs. Alternatively, allogeneic whole tumor-cell vaccines, which typically contain two or three established and characterized human tumor cell lines of a given tumor type, are being used to overcome many logistical limitations of autologous tumor-cell vaccines. The GVAX vaccine platforms (Emens et al., 2009; Laheru et al., 2008; Lutz et al., 2011), which contain allogeneic pancreatic, prostate, or breast tumor cells, are a testament to the ability to provide such a vaccine for multicenter evaluation.

Anti-idiotype vaccines are directed against specific antibodies found on the surface of Blymphoma cells (Belardelli et al., 2004; Inoges et al., 2006; Schuster et al., 2011), and have 
the advantage of targeting a unique tumor-specific antigen. A disadvantage is that their generation and production are quite labor intensive in that, to date, each anti-idiotype vaccine has been patient specific. However, some researchers have shown that these patientspecific vaccines can be produced in less than a month [reviewed in (Bendandi et al., 2009).

\section{A. An Example of Optimizing Vaccine Potency}

The spectrum of therapeutic cancer vaccines is as wide as the spectrum of chemotherapeutics and small molecule targeted therapies. One approach, for example, is to endow the vaccine with as much immunostimulatory potential as possible. The large genome of poxviruses allows one to add transgenes for one or more TAAs and three T-cell costimulatory molecules. The generation of a robust host response to a weak "self-antigen" such as a TAA requires at least two signals. B7.1 (CD80) is one of the most studied costimulatory molecules in its interaction with its CD28 ligand on T cells. Initial studies demonstrated that the admixing of recombinant vaccinia (rV)-TAA with rV-B7.1 resulted in enhanced TAA-specific T-cell responses and anti-tumor immunity compared to either vector alone (Hodge et al., 1995; Kalus et al., 1999). Additional studies were conducted with recombinant vaccinia viruses containing other T-cell costimulatory molecules including LFA-3, CD70, ICAM-1, 4-1BBL, and OX-40L (Kudo-Saito et al., 2006; Lorenz et al., 1999a, et al., 1999b; Uzendoski et al., 1997). Each was shown to enhance antigen-specific Tcell responses, but the combined use of three specific costimulatory molecules (B7.1, ICAM-1, and LFA-3) acted synergistically to further enhance antigen-specific T-cell responses (Fig. 1). Each molecule binds to a different ligand on T-cells and is known to signal through different pathways. This TRIad of COstimulatory Molecules has been designated TRICOM (Table 4). Attempts to add a fourth costimulatory molecule resulted in either a minimal enhancement or reduced immunogenicity to the TAA transgene.

One of the most widely expressed TAAs is CEA (Schlom et al., 2001). One of the issues addressed early on was to optimize induction of CEA-specific $\mathrm{CD} 4^{+}$and $\mathrm{CD} 8^{+} \mathrm{T}$-cell responses in a host tolerant to CEA and in which CEA is a self-antigen. Since mice do not express human CEA, CEA. Tg mice are employed (Clarke et al., 1998). These mice express CEA, as do humans, in fetal tissue and in some adult gut tissues. They also express CEA in sera at levels similar to patients with CEA positive tumors. The challenge was to define the best delivery system to break tolerance to CEA in these mice, and to go on to kill tumors engineered to express human CEA. A recombinant vaccinia expressing the CEA transgene (designated rV-CEA) was constructed and demonstrated superiority to other forms of CEAtargeted therapy (Irvine et al., 1993; Kass et al., 1999). Subsequent studies (Kass, et al., 1999) also demonstrated the superiority of rV-CEA vs. CEA protein in inducing anti-tumor responses. This study and numerous others have dispelled the belief of "antigenic competition" in using poxvirus vectors, i.e., that the poxviral epitopes would interfere with the TAA transgene epitopes for T-cell activation (Larocca et al., 2011).

Evaluation of different vaccine strategies (Aarts et al., 2002; Grosenbach et al., 2001) in the stringent CEA.Tg animal model also demonstrated that (a) a diversified vaccination protocol consisting of primary vaccination with rV-CEA-TRICOM followed by boosting with recombinant fowlpox $(\mathrm{rF})$-CEA-TRICOM is more efficacious than homogeneous 
vaccination with either vector and more efficacious than the use of these vectors with one or no costimulatory molecules (Fig. 2); (b) continued boosting with vaccine was required to maintain CEA-specific T-cell responses. These strategies were combined to optimally treat CEA- expressing carcinoma liver metastases in CEA.Tg mice (Aarts et al., 2002;

Grosenbach et al., 2001).

\section{B. Vaccine/Vaccine Combinations}

Different vaccine platforms directed against the same tumor antigen have been shown to enhance host immunity in different ways and thus may have an additive or synergistic antitumor effect. Using a recombinant poxviral TRICOM vaccine and a yeast (Saccharomyces cerevisiae) vaccine, studies evaluated T-cell populations induced by these two diverse platforms in terms of serum cytokine response, T-cell gene expression, T-cell receptor phenotype, and antigen-specific cytokine expression (Boehm et al., 2010). T-cell avidity, and T-cell antigen-specific tumor cell lysis demonstrated that vaccination with rV,rF-CEATRICOM or heat-killed yeast-CEA elicits T-cell populations with both shared and unique phenotypic and functional characteristics. Furthermore, both the antigen and the vector played a role in the induction of distinct T-cell populations. These studies (Boehm et al., 2010) thus provide the rationale for future clinical studies investigating concurrent or sequential administration of different vaccine platforms targeting a single antigen. Moreover, studies involving the concurrent or sequential use of vaccines targeting different antigens expressed on a heterogeneous tumor mass are clearly warranted.

\section{ANIMAL MODELS TO EVALUATE CANCER VACCINES: PROS AND CONS}

The use of animal models to evaluate different forms of immunotherapy, including vaccine therapy, can be extremely helpful in certain cases and "less than useful" in others. For example, murine models can be extremely useful in evaluating the potency of one vaccine platform vs. another and in determining the mode of action of a given vaccine platform. They are also useful in the evaluation of therapies employing vaccines in combination with other forms of immunotherapy, or other modes of therapeutic intervention, where scheduling of each intervention can potentially be important and can be monitored. There are, however, several major drawbacks in the use of animal models; in particular, murine transplantable tumors grow at an extremely fast rate, in which the time from transplantation to death is usually a matter of weeks. There is a mindset by some that one must be able to "cure large tumor masses" for any immunotherapy to be effective. The clinical correlate of this is chemotherapy or the adoptive transfer of hundreds of millions to billions of $\mathrm{T}$ cells to melanoma patients with large tumor masses. The appropriate utilization of therapeutic cancer vaccines, however, is in the adjuvant or neoadjuvant setting or in patients with minimal residual metastatic disease. Many of these patients have no measurable disease by conventional scanning technologies, but have micrometastatic disease and/or a high risk of recurrence. The evaluation of vaccines and vaccine strategies in animal models thus does not require the use of mice with a large tumor burden, where the tumor mass is a high percentage of the mass of the host. Indeed, the FDA-approved checkpoint inhibitor ipilimumab is ineffective in some models as a monotherapy in mice bearing non- 
immunogenic tumors (Hodge et al., 2005). Moreover, both the Provenge vaccine and ipilimumab were FDA approved on the basis of increased survival and not on the basis of improved time to progression (TTP) or reduction of tumor burden employing RECIST criteria.

Animal models are also inappropriate in the analysis of immunogenicity of human tumorassociated antigens. It is well-known that the immunogenicity of a given antigen may differ greatly between different species and even among different strains of mice. Even the use of HLA-A2 transgenic ( $\mathrm{Tg}$ ) mice may not provide an appropriate answer as to immunogenicity in humans due to the fact that the T-cell receptor repertoire of mice (including A2 Tg) and humans differs appreciably. It is suggested that the appropriate model to determine the potential immunogenicity of a given tumor antigen in humans, short of a clinical trial, is the ability of a given peptide/protein or vaccine to activate human T cells in vitro, which in turn have the ability to lyse human tumors expressing that antigen. Alternatively, analysis of PBMCs from patients who have received vaccine (not containing the tumor antigen in question), or checkpoint inhibitor monoclonal antibody, post-treatment for the generation of $\mathrm{T}$ cells to the tumor antigen in question, i.e., for evidence of epitope spreading/antigen cascade.

\section{TYPES OF IMMUNOTHERAPY}

\section{A. Vaccine Therapy and Adoptive T-cell Transfer: a Study in Contrasts}

Different modes of immunotherapy that target the same tumor antigen can lead to quite distinct results. This is exemplified in a series of studies, both preclinical and clinical involving vaccine therapy and adoptively transferred $\mathrm{T}$ cells, both of which target the TAA CEA. Preclinical studies of both modalities used human CEA.Tg mice where CEA is a selfantigen. In one study, it was indicated that vector (devoid of costimulatory molecules)- or DNA-based vaccine directed against CEA was incapable of rejecting CEA positive tumors (Bos et al., 2008). The study went on to report that "effective tumor targeting is only achieved by adoptive transfer of T cells." However, such treatment resulted in severe intestinal autoimmune pathology associated with weight loss and mortality. In a clinical study (Parkhurst et al., 2011) autologous T cells were genetically engineered to express a Tcell receptor directed against a specific human CEA epitope and $\mathrm{T}$ cells were adoptively transferred to three patients with metastatic colorectal cancer. All patients experienced profound decreases in serum CEA levels (74-99\%) and one patient had an objective regression of cancer metastatic to the lung and liver. However, a severe transient inflammatory colitis represented a dose-limiting toxicity that was induced in all three patients. The authors concluded that this study demonstrated the limitations of using CEA as a target for cancer immunotherapy.

These preclinical and clinical studies are contrasted with the use of vector-based vaccines that contain transgenes for CEA and three human costimulatory molecules (designated TRICOM). Using the same CEA.Tg mice described above, tumor-bearing mice received a prime vaccination with $\mathrm{rV}$-CEA-TRICOM and multiple booster vaccinations with rF-CEATRICOM. Anti-tumor immunity leading to cure in approximately $60 \%$ of mice was achieved in the absence of any evidence of autoimmunity (Hodge et al., 2003a). Indeed, no evidence 
of toxicity was seen employing an array of clinical serum and urine chemistry assays and a comprehensive histopathologic evaluation of all tissues after one year. Similar results were also obtained employing CEA-TRICOM vaccination in CEA.Tg mice crossed with mice bearing a mutation in the APC gene. These mice developed spontaneous intestinal tumors. Vaccination resulted in improved overall survival in the absence of autoimmunity (Greiner et al., 2002), A third study (Zeytin et al., 2004) demonstrated that CEA-TRICOM vaccination in combination with Celecoxib elicits anti-tumor immunity and long-term survival in CEA.Tg/MIN mice in the absence of autoimmunity. Several clinical studies have now shown evidence of anti-tumor immunity in metastatic cancer patients employing CEA-TRICOMand CEA-MUC1-TRICOM-based vaccines in the absence of autoimmunity (Marshall et al., 2005; Morse et al., 2013b). In a Phase II trial, patients with metastatic colorectal cancer to the liver and/or lung were vaccinated with PANVAC vaccine (rV-, rF-CEA- MUC1TRICOM) following metastasectomy (Morse et al., 2013b). At approximately 40 months follow-up, $90 \%$ of the vaccinated patients survived vs. approximately $47 \%$ in the contemporary control group. Overall survival of colorectal cancer patients after metastasectomy in five other trials ranged from 28-58\% (Andres et al., 2008; Arru et al., 2008; Choti et al., 2002; House et al., 2010; Pawlik et al., 2005; Sasaki et al., 2005). Moreover, no evidence of autoimmunity was reported in the patients receiving PANVAC. This trial will be discussed in detail below. These studies demonstrated the balance that can indeed be achieved between the induction of an anti-tumor immune response to a selfantigen and the absence of autoimmunity and illustrated the distinctions between different forms of immunotherapy targeting the same antigen.

\section{THE IMPORTANCE OF ANTIGEN CASCADE IN VACCINE-MEDIATED THERAPEUTIC RESPONSES}

Studies have been undertaken (Kudo-Saito et al., 2007; Kudo-Saito et al., 2005a) to determine the range of specific immune responses associated with vaccination-mediated tumor regression. In one model, CEA.Tg mice bearing $\mathrm{CEA}^{+}$tumors were vaccinated with the CEA-TRICOM subcutaneous/intratumoral (s.c./i.t.) regimen, and anti-tumor (Fig. 3, top panel) and T-cell immune responses were assessed. These studies showed that CEA was needed to be present in both the vaccine and the tumor for therapeutic effects. T-cell responses could be detected not only to CEA (the antigen encoded in the vaccine) but also to other antigens expressed on the tumor: wild-type p53 and an endogenous retroviral epitope of gp70 (Fig. 3, middle panel A, B, C). Moreover, the magnitude of CD8 ${ }^{+}$T-cell immune responses to gp70 was far greater than that induced to CEA or p53. Finally, the predominant T-cell population infiltrating the regressing $\mathrm{CEA}^{+}$tumor after therapy was specific for gp70 (Fig. 3, middle panel D-I). Challenge of cured mice with tumors expressing only CEA, only gp70, both antigens, or none showed that the predominant anti-tumor effect was due to gp70, i.e., the cascade antigen (Fig. 3, lower panel). Clinical studies in breast cancer patients also showed that there was a correlation with clinical benefit for those patients who demonstrated the phenomenon of antigen cascade/epitope spreading in PBMCs post-vaccination (Disis et al., 2009, et al., 2011; Hardwick et al., 2011; Walter et al., 2012). These studies showed that the breadth and magnitude of anti-tumor immune cascades to multiple antigens can be 
critical in the therapy of established tumors. These studies also indicate the potential utility of vaccines in addressing the issue of tumor cell phenotypic heterogeneity.

\section{TRICOM-BASED VACCINES: CLINICAL STUDIES}

Three of the most widely studied human TAAs are CEA, mucin-1 (MUC-1), and PSA. CEA is overexpressed in a wide range of human carcinomas, including gastrointestinal, breast, lung, pancreatic, medullary thyroid, ovarian, and prostate. MUC-1 is a tumor-associated mucin, which is overexpressed and hypoglycosylated in all human carcinomas as well as in acute myeloid leukemia (AML) and multiple myeloma. The elegant studies of Kufe and colleagues (Kufe et al., 2009; Raina et al., 2011), as well as others, have demonstrated that the C-terminus of MUC-1 functions as an oncogene. Numerous preclinical studies and recent clinical studies have demonstrated the importance of the induction of CD8 ${ }^{+} \mathrm{T}$-cell responses in vaccine-mediated anti-tumor immunity. Both the number and avidity of $\mathrm{T}$ cells can contribute to tumor cell lysis. Indeed, it has been shown that high avidity $\mathrm{T}$ cells can lyse targets with up to 1,000-fold lower peptide-MHC complexes than low avidity T cells (Derby et al., 2001; Hodge et al., 2005; Oh et al., 2003). Since the majority of tumor antigens are "self antigens," they will by nature induce lower avidity T cells. Even some gene products of somatic mutations, such as point mutated ras, will generate $\mathrm{T}$ cells of much lower avidity when compared to T cells induced by microbial antigens such as influenza. For this reason, strategies have been undertaken to enhance both the number and avidity of T cells to tumorassociated antigens. One such strategy is the design of enhancer agonist epitopes. The PROSTVAC vaccine (rV,rF-PSA-TRICOM) contains an enhancer epitope for PSA, and the PANVAC vaccine (rV,rF-CEA-MUC1-TRICOM) contains enhancer epitopes for both CEA and MUC1 (Table 4). Both PROSTVAC and PANVAC are "off the shelf" vaccines that can be easily distributed for multicenter clinical trials (Fig. 4).

We conducted the first TRICOM trial in humans (Marshall et al., 2005) with rV-, rF-CEATRICOM vaccines. Twenty-three out of 58 patients (40\%) had stable disease for at least four months, with 14 (24\%) of these patients having prolonged stable disease (> 6 months). Eleven patients had decreasing or stable serum CEA, and one patient had a pathologic complete response. Enhanced CEA-specific T-cell responses were observed in the majority of patients tested.

An early clinical study (Gulley et al., 2008) treated 25 patients with multiple types of cancer with the poxviral vaccine regimen consisting of the genes for CEA and MUC-1, along with TRICOM, engineered into vaccinia (PANVAC-V) as a prime vaccination and into fowlpox (PANVAC-F) as a booster vaccination. The vaccine regimen was well tolerated. Immune responses to MUC-1 and/or CEA were seen following vaccination in nine of 16 patients tested. A breast cancer patient had a confirmed decrease of $>20 \%$ in the size of large liver metastases, and a patient with clear cell ovarian cancer and symptomatic ascites had a durable (18-month) clinical response radiographically and biochemically.

Another study (Mohebtash et al., 2011) was conducted to obtain preliminary evidence of clinical response in metastatic breast and ovarian cancer patients with PANVAC. Twenty-six patients were enrolled and given monthly vaccinations. These patients were heavily 
pretreated, with 21 of 26 patients having had three or more prior chemotherapy regimens. Side effects were largely limited to mild injection-site reactions. For the 12 breast cancer patients enrolled, median overall survival (OS) was 13.7 months. Four patients had stable disease beyond their first restaging. One patient had a complete response by RECIST and remained on study for over 37 months. Another patient with metastatic disease confined to the mediastinum had a reduction in a mediastinal mass and was on study for 10 months. Patients with stable or responding disease had fewer prior therapies and lower tumor marker levels than patients with no evidence of response. Further studies to confirm these results are warranted.

A Phase II trial was also conducted in colorectal cancer patients following metastasectomy (surgical removal of lung or liver metastases). In this multicenter trial (Morse et al., 2013b). 74 patients who had no evidence of disease after resection and completion of their physician-determined perioperative chemotherapy were vaccinated with PANVAC (ie, with vaccine alone or with vaccine-modified DCs). Data from a prospectively registered, comparable contemporary control group of colorectal cancer patients who had undergone metastasectomy were also available (Morse et al., 2013b). The 2-year relapse-free survival was similar in all groups: 47\% for the DC-PANVAC group, 55\% for the PANVAC group, and $55 \%$ for the contemporary control group. However, the 2-year OS was $95 \%$ for the vaccinated groups and $75 \%$ for the contemporary control group; after approximately 40 months of follow-up, 67 of 74 (90\%) of the vaccinated patients survived vs. approximately $47 \%$ overall survival (OS) in the contemporary control group; the data for 3- to 5-year survival data of colorectal cancer patients after metastasectomy in five other trials ranges from 28\% to 58\% (Andres, et al., 2008; Arru et al., 2008; Choti et al., 2002; House, et al., 2010; Pawlik et al., 2005; Sasaki et al., 2005). A randomized trial is necessary to confirm these results. It is of interest, however, that this is yet another example of a vaccine trial that shows little or no evidence of an improvement in relapse-free survival, yet has an apparent benefit in overall survival (Hoos et al., 2010).

\section{PROSTATE CANCER CLINICAL TRIALS}

While the vast majority of prior and ongoing vaccine trials have been conducted in patients with metastatic melanoma, several characteristics render carcinoma patients with minimal disease burden or in the adjuvant and/or neoadjuvant setting as amenable to vaccine therapy. Prostate cancer can be considered as a prototype disease for the evaluation of therapeutic cancer vaccines (Madan et al., 2010a): (a) Prostate cancer is generally an indolent disease that may not lead to metastatic disease or death for over a decade or more; consequently, time is often required for a vaccine to generate a sufficient immune response capable of curtailing disease growth; (b) prostate cancer cells express a variety of well-characterized TAAs; (c) the serum marker PSA can be used to identify patients with minimal tumor burden and those responding to therapy; and (d) a well-defined nomogram, the Halabi nomogram (Halabi et al., 2003), can be used at presentation of metastatic disease to predict probable response to standard-of-care chemotherapy and/or hormone therapy. 


\section{A. PSA-TRICOM (PROSTVAC) Studies}

A series of clinical trials were conducted to determine the safety and efficacy of PSA-based vaccines. A Phase I study was first conducted to demonstrate the safety of rV-, rF-PSATRICOM (PROSTVAC) in patients with prostate cancer (Arlen et al., 2007). PROSTVACVF was then evaluated for prolongation of progression-free survival (PFS) and OS in a 43center randomized, controlled, and blinded Phase II study (Kantoff et al., 2010b). In total, 125 patients with minimally symptomatic mCRPC were randomly assigned. Patients were allocated (2:1) to PROSTVAC-VF plus GM-CSF or to control empty vectors plus saline injections. Eighty-two patients received PROSTVAC-VF and 40 received control vectors. Patient characteristics were similar in both groups. The primary end point was PFS, which was similar in the two groups $(P=0.6)$. However, at three years post-study, PROSTVAC-VF patients had a better OS with $25(30 \%)$ of 82 alive vs. seven (17\%) of 40 controls, and longer median survival by 8.5 months ( 25.1 months for vaccinated patients vs. 16.6 months for controls), an estimated hazard ratio of 0.56 (95\% CI, 0.37 to 0.85 ), and stratified $\log$ rank $P=0.0061$ (Fig. 5A). PROSTVAC-VF immunotherapy was well tolerated and associated with a $44 \%$ reduction in the death rate and an 8.5-month improvement in median OS in men with mCRPC. These results compare quite favorably with those of the Phase III trials results of Sipuleucel-T vaccine in a similar patient population (Fig. 5B). The provocative data with the PROSTVAC vaccine provided evidence of clinically meaningful benefit; a 1,200-patient global Phase III study is ongoing.

In a concurrent Phase II study (Gulley et al., 2010b), 32 patients were vaccinated once with rV-PSA-TRICOM and received boosters with rF-PSA-TRICOM. Twelve of the patients showed declines in serum PSA post-vaccination and two of 12 showed decreases in index lesions. Median OS was 26.6 months (predicted median OS by the Halabi nomogram was 17.4 months) (Fig. 6A). Patients with greater PSA-specific T-cell responses showed a trend $(P=0.055)$ toward enhanced survival (Fig. 6B). There was no difference in T-cell responses or survival in cohorts of patients receiving GM-CSF vs. no GM-CSF. In a concurrent Phase II trial conducted at the same institution (NCI), the Halabi nomogram accurately predicted survival in a similar patient population receiving the standard-of-care drug docetaxel. In the vaccine trial, patients with a Halabi predicted survival (HPS) (Halabi et al., 2003) of <18 months (median predicted 12.3 months) had an actual median OS of 14.6 months, while those with an HPS of $\geq 18$ months (median predicted survival 20.9 months) will meet or exceed 37.3 months, with 12 of 15 patients living longer than predicted $(P=0.035)$.

Regulatory T-cell (Treg) suppressive function was also shown to decrease following vaccine in patients surviving longer than predicted, and increase in patients surviving less than predicted (Gulley et al., 2010b). Trends were also observed in increased effector:Treg $\left(\mathrm{CD} 4{ }^{+} \mathrm{CD} 25^{+} \mathrm{CD} 127^{\text {neg }}{ }^{\mathrm{FoxP}} 3^{+} \mathrm{CTLA} 4^{+}\right)$ratios post- vs. pre-vaccination with OS vs. HPS. This hypothesis-generating study provided evidence that patients with more indolent mCRPC (HPS $\geq 18$ months) may best benefit from vaccine therapy.

It has also been hypothesized that vaccine therapy will have significant benefit in patients with minimal disease recurrence. To test this, hormone naive patients $(n=50)$ with micrometastatic disease were vaccinated with PROSTVAC (DiPaola et al., 2009). Among 29 patients with follow-up > 6 months, the PSA progression-free rate at six months (the 
primary endpoint) was $66 \%$. Pre-treatment PSA slope was $0.17 \log$ PSA/month (median PSA doubling time 4.4 months), in contrast to the on-treatment slope of $0.12 \log$ PSA/month (median PSA doubling time 7.7 months), $\mathrm{p}=0.002$. PROSTVAC vaccine can thus be administered safely with preliminary evidence of patient benefit in the multi-institutional cooperative group setting to patients with minimal disease volume (DiPaola et al., 2009).

\section{B. Vaccines and Tumor Growth Rates}

One of the confounding phenomena involving therapeutic cancer vaccines is the disconnect, seen in several clinical trials, between an increase in OS in vaccinated patients (vs. control cohorts) and the lack of a corresponding statistical increase in time to progression and/or tumor shrinkage using RECIST criteria. Indeed, in the two FDA-approved immunotherapeutics (Provenge vaccine and ipilimumab), a statistical increase in OS was not accompanied by an increase in TTP, as mentioned above. This was also seen in the PROSTVAC trial in metastatic prostate cancer patients. This phenomenon and the disconnect with results observed with cytotoxic drugs has now been studied (Stein et al., 2011).

In patients who are treated with traditional cytotoxic agents, improved TTP is believed to be a prerequisite for improved OS. A recent study (Stein et al., 2011) evaluated tumor regression and growth rates in four chemotherapy trials and one vaccine trial in patients with mCRPC. Figure 7A illustrates the growth rate constants observed in that study. Cytotoxic agents affect the tumor only during the period of administration; soon after the drug is discontinued, due to drug resistance or toxicity, tumor shrinkage ceases and the growth rate of the tumor increases (Fig. 7A, line b). With vaccine therapy, the mechanism of action and kinetics of clinical response appear to be quite different (Stein et al., 2011). Therapeutic vaccines do not directly target the tumor; rather, they target the immune system. Immune responses often take time to develop and can potentially be enhanced by continued booster vaccinations. Any resulting tumor cell lysis as a consequence of vaccination can lead to cross-priming of additional TAAs; this can take place via the uptake of lysed tumor cells by host APCs, which activate more T cells to other antigens in the tumor, thus broadening the immune repertoire (a phenomenon known as "antigen cascade" or "epitope spreading"). This broader, and perhaps more relevant, immune response may also take some time to develop. This phenomenon is demonstrated in the preclinical model depicted in Figure 3 (Kudo-Saito et al., 2005b).

Although a vaccine may not induce any substantial reduction in tumor burden, vaccines as monotherapy have the potential to apply anti-tumor activity over a long period, resulting in a slower tumor growth rate (Fig. 7A, line c). This deceleration in growth rate may continue for months or years and, more importantly, through subsequent therapies. This process can thus lead to clinically significant improved OS, often with little or no difference in time to progression and a low rate of, or lack of, objective response (Fig. 7A, line c). Thus, treating patients with a vaccine when they have a lower tumor burden, as compared with a greater tumor burden, may result in far better outcomes (Fig. 7B, line d vs. line e). Early clinical trials with vaccine may have been terminated prematurely with the observance of tumor progression before sufficient vaccine boosts could be administered. The realization of this 
phenomenon has now led to modifications in how vaccine clinical trials are designed and to new "immune response criteria" for immunotherapy (Hoos et al., 2010). It is also believed that the combined use of vaccine and cytotoxic therapy, or with a small molecule targeted therapeutic, may result in both tumor regression (via the cytotoxic therapy) and reduced tumor growth rate (via vaccine therapy) (Fig. 7C) (Gulley et al., 2010a; Gulley et al., 2011; Madan et al., 2010b; Stein et al., 2011). These concepts will be discussed below.

\section{A Case Report: Analysis of a Prostate Cancer Patient Over an 8-Year Period}

This patient was 60 years old when initially diagnosed with prostate cancer on the basis of a PSA level of $11.9 \mathrm{ng} / \mathrm{mL}$ (Rojan et al., 2013), (Fig. 8, point A). A prostate biopsy specimen revealed Gleason 7 adenocarcinoma. He was treated with radical prostatectomy and was found to have disease involving both lobes of his prostate extending outside the capsule to the inferior margin (stage T3a). After radical prostatectomy, his PSA level became undetectable $(<0.2 \mathrm{ng} / \mathrm{mL})$ and remained so for two years (Fig. 8, point B). His PSA level then began to rise over the next four years. A scan demonstrated abnormal activity only in the prostate bed, and he was treated with external beam radiation therapy. However, his PSA level continued to rise without any apparent effect of the radiation on his PSA doubling time.

Seven and a half years after prostatectomy his PSA level continued to rise. He enrolled in an Eastern Cooperative Oncology Group Phase II clinical trial and received four doses of a PSA-TRICOM vaccine. Five months after receiving his last vaccination, his PSA level had risen to $12.9 \mathrm{ng} / \mathrm{mL}$ before gradually declining and reaching a nadir of $4.3 \mathrm{ng} / \mathrm{mL}$ (a $67 \%$ decrease 9.2 years after prostatectomy).This nadir was short-lived and his PSA level began to rise within one year. However, in contrast to his pre-vaccine PSA doubling time, his doubling time slowed to 2.6 years over the next five to six years (Fig. 8, slope \#1 vs. slope \#3). Approximately 11 years after prostatectomy and four years after initial vaccination, a compassionate-use single-patient institutional review board application was approved and he was vaccinated with PROSTVAC vaccine. He subsequently experienced a slowing in his PSA velocity. Since then, his PSA level has declined spontaneously (Fig. 8, slope \#4) without intervention. His most recent PSA level was $3.5 \mathrm{ng} / \mathrm{mL}$ (19.3 years after prostatectomy). This patient originally had a PSA doubling time of 10 months and as such would have been expected to have a median actuarial time to metastases of eight years (from the time of PSA elevation) and a median actuarial time to death after development of metastases of five additional years (Pound et al., 1999). However, he has not required hormonal treatment or chemotherapy in almost 18 years since his biochemical recurrence, and therefore his course has greatly exceeded expectations. Because spontaneous declines in PSA levels are rare in the absence of therapy, it is believed that the ongoing PSA decline in this patient was caused by the combined effect of both sets of vaccinations. Of note, the patient's testosterone levels have been in the low-normal range and much greater than castration levels, arguing against waning testosterone levels causing PSA decline. Anti-PSA antibodies that could decrease PSA levels by pulling PSA out of circulation were not detected on multiple occasions. It is of interest that the decline after the second series of vaccinations did not occur for approximately 3.5 years, consistent with observations that responses to vaccines can be quite delayed (Gulley et al., 2013). 


\section{VACCINE COMBINATION THERAPIES}

It was commonly assumed that chemotherapy and vaccine therapy are not compatible. However, preclinical studies have demonstrated, and early clinical evidence is now emerging, that multiple non-immune modalities of therapy can be used concurrently with cancer vaccines or immediately after vaccine therapy, with additive or synergistic effects. Some of these modalities are summarized in Table 5.

Certain chemotherapeutic agents can enhance vaccine-mediated T-cell killing by several different mechanisms. Oxaliplatin and anthracyclines, such as doxorubicin, will induce what has been termed "immunogenic tumor cell death," which results in enhanced cross-priming of TAAs by DCs and subsequent activation of T cells (Kepp et al., 2011; Locher et al., 2010; Tesniere et al., 2010; Zitvogel et al., 2010). Other chemotherapies have been shown to suppress certain types of immune regulatory cells and/or enhance the ratio of effector $T$ cells to suppressor $\mathrm{T}$ cells (as will be discussed below). Certain chemotherapeutic agents and small molecule targeted therapies have also been shown to induce "immunogenic modulation" of tumor cells. This results in an increased expression of TAAs, peptide-MHC complexes, adhesion molecules, and death receptors such as Fas on the surface of tumor cells and thus render the tumor cells more susceptible to vaccine-induced T-cell killing (Garnett et al., 2004; Kodumudi et al., 2010); this same phenomenon has been observed when tumor cells have been exposed to external beam radiation, radiolabeled monoclonal antibodies, and chelated bone-seeking radionuclides (Chakraborty et al., 2004; Chakraborty et al., 2008a; Gelbard et al., 2006).

Hormonal therapy that is used in the treatment of several different stages of prostate cancer has been shown to induce thymic regeneration and the induction of naive T cells(Lee et al., 2010; Sportes et al., 2010; Williams et al., 2008); it is at this interval that vaccine therapy may be most effective (Arredouani et al., 2010; Sanda et al., 1999). A clinical study has demonstrated increased levels of infiltrating $\mathrm{T}$ cells in prostate cancer biopsies post- (vs. pre-) hormonal therapy.

\section{COMBINATION THERAPIES - PRECLINICAL STUDIES}

There have been numerous studies combining different forms of radiation with vaccine therapy. Below are some examples.

\section{A. Vaccine and Radiation Synergy}

A synergy has been demonstrated between local radiation of tumor and vaccine therapy (Chakraborty et al., 2004; Kudo-Saito et al., 2005a). CEA.Tg mice with developing MC38 murine carcinoma cells transfected with CEA were treated with rV-, rF-CEA-TRICOM. One dose of 8-Gy radiation to tumor induced upregulation of the death receptor Fas (CD95) in situ for up to 11 days. When vaccine therapy and local radiation of tumor were used in combination, as opposed to individually, dramatic and significant cures were achieved (Chakraborty et al., 2004; Kudo-Saito et al., 2005a).This was shown to be mediated by the engagement of the Fas/Fas ligand pathway. 
One of the issues with radiation therapy is the non-lethal dose of radiation that some tumor cells will receive due to issues of normal tissue toxicity or their location outside the field being irradiated. Twenty-three human carcinoma cell lines (12 colon, seven lung, and four prostate) were examined for their response to non-lytic doses of radiation (Garnett et al., 2004). Seventy-two hours post-irradiation, changes in the expression of surface molecules involved in T-cell-mediated immune attack such as specific TAAs and MHC class I, and Fas were examined. Twenty-one of the $23(91 \%)$ cell lines upregulated one or more of these surface molecules post-irradiation. Overall, the results of this study suggested that nonlethal doses of radiation can be used to make human tumors more amenable to T-cell attack.

Another study (Chakraborty et al., 2008b) explored the possibility that exposure to palliative doses of a radiopharmaceutical agent could also alter the phenotype of tumor cells to render them more susceptible to T-cell-mediated killing. LNCaP tumor cells exposed to (153)SmEDTMP, which is used to treat pain due to bone metastasis, also upregulated the surface molecules such as Fas, CEA, MUC-1, MHC class I, and ICAM-1, and rendered LNCaP cells more susceptible to killing by CTLs specific for PSA, CEA, and MUC-1.

\section{B. Vaccines in Combination with Chemotherapy}

Taxanes are commonly used to treat breast, prostate, and lung cancers, among others. One murine in vivo study (Garnett et al., 2008), for example, showed that docetaxel modulates $\mathrm{CD}^{+}, \mathrm{CD}^{+}, \mathrm{CD} 19^{+}, \mathrm{NK}$ (natural killer) and Treg populations in non-tumor-bearing mice, and docetaxel combined with CEA-TRICOM vaccination is superior to either agent alone at reducing tumor burden.

\section{Vaccine in Combination with Small Molecule Targeted Therapies}

Studies (Farsaci et al., 2012; Finke et al., 2008) have investigated the immunomodulatory effects of sunitinib to rationally design a potential combinational platform with vaccine therapy. In one study, the effect of differently timed combinations of sunitinib and CEATRICOM vaccine in CEA.Tg mice was evaluated. In vivo, one cycle of sunitinib caused bimodal immune effects: (a) decreased regulatory cells during the four weeks of treatment and (b) an immune-suppression rebound during the two weeks of treatment interruption. Continuous sunitinib followed by vaccine, however, increased intratumoral infiltration of antigen-specific T lymphocytes, decreased immunosuppressant Tregs and myeloid-derived suppressor cells, reduced tumor volumes and increased survival. These studies showed that the immunomodulatory activity of continuous sunitinib can create a more immunepermissive environment for combination therapy with vaccine. Small molecule BCL-2 inhibitors are being examined as monotherapy in Phase I/II clinical trials for several types of tumors. Activated mature $\mathrm{CD}^{+} \mathrm{T}$ lymphocytes were shown (Farsaci et al., 2010) to be more resistant to a BCL-2 inhibitor as compared to early-activated cells. In vivo, optimal antitumor activity was obtained when the BCL-2 inhibitor was given after vaccination so as to not negatively impact the induction of vaccine-mediated immunity; this resulted in an increase in the $\mathrm{CD}^{+}$:Treg ratio and significant reduction of pulmonary tumor nodules (Fig. 9). These studies and others also undermine the importance of scheduling of a given "nonimmune" therapeutic with vaccine therapy. 


\section{The Effect of Non-immune Therapeutic Interventions on Immune Cells}

As discussed below, the interplay of host immunity with many standard-of-care therapies such as chemotherapy, radiation, hormonal therapy, and small molecule targeted therapeutics is now becoming apparent through several lines of investigation. For many cancer types, the specific immune infiltrate in the primary tumor is a strong and independent predictor of response to subsequent therapies, and is thus a strong prognostic indicator (see(Fridman et al., 2012; Galluzzi et al., 2012; Galon et al., 2012; Jochems, C. et al., 2011)for reviews). Preclinical studies and some clinical studies have shown that certain chemotherapeutic agents and small molecule targeted therapeutics can have differential effects on specific components of the immune system that can lead to enhanced or reduced antitumor effects (Adotevi et al., 2010; Emens et al., 2009; Finke et al., 2008; Ko et al., 2010; Ko et al., 2009; Vanneman et al., 2012). These phenomena have potentially important implications in designing clinical trials of the combined use of "non-immune" therapies with immunotherapeutic agents such as cancer vaccines.

Many preclinical studies and some clinical studies have provided evidence that Tregs play an important role in inhibiting immune responses to active immunotherapy protocols employing agents such as therapeutic cancer vaccines or checkpoint inhibitors. Studies have also demonstrated that both the number and suppressive function of Tregs on effector $\mathrm{T}$ cells need to be investigated. To provide insight toward the possibility of how active immune therapies can be employed in combination with non-immune standard-of-care therapies of carcinoma patients, both number and function of Tregs obtained from peripheral blood of cancer patients was investigated both prior to and during therapy with two chemotherapy regimens and two targeted therapy regimens. These studies showed that tamoxifen plus GnRH treatment had minimal effects on Tregs in breast cancer patients, and the effect of sunitinib had differential effects on Tregs among patients with metastatic renal carcinomas (Roselli et al., in press). However, the use of the two chemotherapy regimens, docetaxel in patients with both metastatic prostate cancer and metastatic breast cancer (Fig. 10), and cisplatin plus vinorelbine in patients with non-small cell lung cancer (Fig. 11), each resulted in statistically significant increases in $\mathrm{CD}^{+}$:Treg ratios, and reduced functional suppressive activity of Tregs post-therapy in the majority of patients (Roselli et al., in press). These studies provide further rationale for the use of vaccines in combination with certain standard-of-care therapies for patients with carcinomas.

\section{INFLUENCE OF THE TUMOR MICROENVIRONMENT AND IMMUNOSUPPRESSIVE FACTORS}

One of the major reasons for the limited success of therapeutic cancer vaccines to date is likely to be the negative influence of the tumor microenvironment and other immunosuppressive factors (Cham et al., 2008; Gajewski et al., 2006a; Gajewski et al., 2006b). Preclinical studies have shown that the interstitial pressure within a large tumor mass diminishes diffusion of macromolecules, such as antibodies, and effector cells, such as T cells (Carmeliet et al., 2011; Fukumura et al., 2010). Most solid tumors also lack T-cell costimulatory molecules. Thus, when activated T cells, especially those of relatively low avidity directed against self-antigens, bind to tumors lacking costimulatory molecules, they 
are anergized and lose lytic capacity. Similarly, it has been shown in preclinical models of chronic viral infection that $\mathrm{T}$ cells chronically exposed to viral antigen can become exhausted (Kim et al., 2010; Mueller et al., 2009). The inhibitory co-receptor programmed death 1 (PD-1) has been shown to be present on such exhausted T cells (Vezys et al., 2011), and PDL1 on the surface of tumor cells can anergize tumor-infiltrating T cells. The use of cancer vaccines with checkpoint inhibitors such as anti-CTLA4 (ipilimumab), anti-PD1, and anti-PDL1 is thus a quite fertile area of investigation. One such clinical trial combining PROSTVAC vaccine with ipilimumab will be discussed below.

\section{VACCINE COMBINATION THERAPIES - CLINICAL STUDIES}

Several hypothesis-generating clinical trials were first conducted in prostate cancer patients with vaccine in combination with hormonal therapy, radiation, or chemotherapy (Arlen et al., 2006; Arlen et al., 2005; Gulley et al., 2005; Madan et al., 2008). In one trial, 42 nonmetastatic prostate cancer patients were randomized to receive vaccine (rV-PSA + rV-B7.1 followed by rF-PSA boosts) vs. second-line antiandrogen therapy with nilutamide (Arlen, et al., 2005). A survival analysis at 6.5 years from the initiation of therapy on this trial has been reported (Madan et al., 2008). Median survival exhibited a trend toward improvement for patients initially randomized to the vaccine arm (median, 5.1 vs. 3.4 years) These data suggested that patients with more indolent disease may derive clinical benefit from vaccine alone or vaccine before second-line hormone therapy compared with hormone therapy alone or hormone therapy followed by vaccine. A study is currently enrolling patients with nonmetastatic CRPC on testosterone suppression therapy who have a rising PSA. The first 26 patients enrolled were evaluated. Median time to progression was 223 days for flutamide + PSA- TRICOM vs. 85 days for flutamide alone (Bilusic et al.). Two Phase II trials are also ongoing in both early and metastatic prostate cancer where patients are randomized to receive the newly FDA-approved androgen receptor antagonist enzalutamide \pm PROSTVAC vaccine (NCT01867333 et al; NCT01875250 et al.).

A combination therapy randomized Phase II study has recently been completed in metastatic prostate cancer patients with bone metastases. Patients received the bone-seeking radionuclide conjugate $153 \mathrm{Sm} \pm$ PROSTVAC vaccine. While this was a small trial there was a clear trend in improved TTP in the combination arm (Heery et al., 2013).

Preclinical studies in mice have shown that CTLA4 blockade can, among other reported activities, increase T-cell avidity, leading to enhanced T-cell-mediated immune responses to the vaccine (Allison et al., 1998; Egen et al., 2002; Hodge, Chakraborty, Kudo-Saito, Garnett and Schlom et al., 2005).

Ipilimumab (Yervoy) is an antagonistic anti-CTLA4 monoclonal antibody that blocks the activity of CTLA4 (Beer et al., 2008; Small et al., 2007; Wolchok et al., 2010). A Phase III randomized trial of ipilimumab in patients with metastatic melanoma showed a significant improvement in overall survival, but no significant improvement in TTP, relative to an active control group (Hodi et al., 2010). The PSA-TRICOM vaccine is designed to enhance T-cell costimulation through enhanced expression of the transgenes of three T-cell costimulatory molecules (CD58, CD80, and ICAM1) on APCs engaging their respective ligands on T 
cells. CD80 is known to react with CD28 on T cells for positive co-stimulation, and with CTLA4 for immune inhibition. The antagonist monoclonal antibody anti-CTLA4 was designed to interrupt this negative signal and enhance immunity. It was thus unclear how a vaccine such as PSA-TRICOM, with its positive co-stimulation, would interact in terms of safety and efficacy with an anti-CTLA4 monoclonal antibody designed to block negative costimulatory signals, especially in view of the severe immune-related adverse events noted in some patients receiving anti-CTLA4 alone. A study was conducted to assess fixed doses of PSA-TRICOM with escalating doses of ipilimumab, with the aim of establishing the safety and tolerability of these combined treatments. The results showed that the combination of a vaccine that enhances immune costimulation with an immune checkpoint inhibitor does not seem to be associated with increased immune-related adverse events compared with ipilimumab alone. There also appeared to be a survival benefit in patients receiving PROSTVAC + the $10 \mathrm{mg} / \mathrm{kg}$ dose of ipilimumab vs. lower doses of ipilimumab (Madan et al., 2012), (Fig. 12). The results compare quite favorably with the results of a Phase II study employing PROSTVAC alone in a similar population. There also appeared to be a greater serum PSA response in the chemotherapy naïve patients in the combination study (Madan et al., 2012), (Fig. 13). A Phase III trial of ipilimumab with radiation in advanced metastatic prostate cancer did not show a statistical survival benefit, i.e., only a 1.2-month difference in OS vs. the placebo arm (Gerritsen et al., 2013). The results of this trial using ipilimumab alone, which is in contrast with the results of two trials using vaccine plus ipilimumab (Madan et al., 2012; van den Eertwegh et al., 2012), provide evidence that the combination of ipilimumab + vaccine may be more efficacious than the use of either agent alone. While the various combination therapy trials discussed above all provided preliminary evidence of improved patient outcome when vaccine is added to another therapy, these results must be considered as only hypothesis generating. Larger randomized trials are required to substantiate such findings.

\section{BIOMARKERS}

The most common biomarker used in vaccine therapy trials has been the immune response of patients to TAAs post- vs. pre-vaccination. Most trials have analyzed antibody responses to TAAs and/or analyzed PBMCs for $\mathrm{CD}^{+}$and/or $\mathrm{CD} 4^{+}$responses to the TAA in the vaccine using enzyme-linked immunosorbent spot (ELISPOT) - or fluorescence-activated cell sorting (FACS)-based assays for cytokine production, or by binding of a peptide tetramer complex to the surface of T cells. Preclinical studies have shown, however, that the level of cytokine production by a $\mathrm{T}$ cell is not always associated with its lytic capacity. Because of the limited availability of samples, however, few studies have actually been able to measure the lytic capacity of T cells. Moreover, with the exception of melanoma, tumor biopsy specimens - the more appropriate site to obtain TAA-specific T cells - are usually unavailable in many trials. Recently, a more comprehensive analysis of immune cell subsets from PBMCs has occurred in some studies including, in addition to T-cell responses, analyses of Tregs, MDSCs, NK, and DCs (Butterfield et al., 2011; Disis et al., 2011). Ratios of effector to regulatory cells have also been analyzed (Gulley et al., 2010b). Numerous studies have also used analyses of multiple serum cytokines and chemokines. 
Bioassays from several studies have seen associations between clinical outcome and a given immune assay; however, these results are far from having identified any one assay as a "surrogate" for clinical benefit. Potential reasons for this may be that PBMC analyses may not reflect which immune cells are actually at the tumor site. Few studies have actually analyzed the "antigen cascade" phenomenon, where the true correlate of clinical benefit may be a T-cell population directed against a TAA not in the vaccine, but generated via crosspriming. Only recently has survival benefit emerged as a prominent endpoint in many vaccine studies for comprehensive correlative analyses with survival. The diversity of the immune responses among individuals may not allow any one marker or set of markers as a surrogate for clinical response. Even analyses of patients' immune response to influenza have been confounding. While antibodies to flu hemaglutinin are used as a "surrogate" for protection in population studies, they do not predict protection from flu for an individual vaccine (Nakaya et al., 2011).

\section{VACCINE TARGETS INVOLVED IN TUMOR PROGRESSION AND DRUG RESISTANCE}

Much attention continues to be paid in the development of small molecule targeted therapeutics and monoclonal antibodies that target gene products involved in tumor initiation, i.e., oncogenes, and to tumor suppressor genes. Equally important, however, are those genes and gene products involved in tumor progression, i.e., those gene products associated with tumor invasion, metastasis, and drug resistance. The phenomena of solid tumor cell "stemness" and EMT are such processes. Evidence is now emerging that "cancer stem cells" are more "plastic" than originally believed, and the distinction between cancer cell "stemness" and EMT is becoming more blurred. EMT is a reversible process during which cells switch from a polarized, epithelial phenotype into a highly motile, mesenchymal phenotype (Kalluri et al., 2009; Thiery et al., 2006). While EMT is a normal process during embryogenesis and organogenesis, numerous observations now support the concept that EMT also plays an essential role in the progression of carcinomas (Thiery et al., 2002). During the metastasis of carcinomas, tumor cells must undertake a series of sequential steps that will allow them to detach from the primary tumor mass and to finally reach the distant sites of metastasis. By undergoing EMT, tumor cells can acquire the ability to move and to invade the surrounding tissues, two fundamental properties for tumor dissemination. In addition, several reports are now indicating that tumor cells undergoing EMT also acquire stem cell-like features and mechanisms of resistance to cell death (Arumugam et al., 2009; Vega et al., 2004). The induction of EMT in various cancer cell lines, for example, has been shown to positively correlate with resistance to radiation (Kurrey et al., 2009), chemotherapy (Yang et al., 2006), and epidermal growth factor receptor (EGFR) kinase inhibitors (Thomson et al., 2005). Many of the molecules known to be mediators of EMT or stemness are transcription factors and/or intracellular molecules. Thus for these to be targets of vaccine-mediated therapy, one must demonstrate that they are processed intracellularly and transported to the cell surface in the context of peptide-MHC complexes in both APCs and targeted tumor cells. Two examples of such potential targets are Brachyury and the Cterminus of MUC1. 
Studies have demonstrated that the gene Brachyury functions as a master regulator of EMT in human carcinoma cells. The upregulation of Brachyury in human epithelial cancer cells results in morphological changes representative of EMT, including the acquisition of a fibroblast-like morphology, the loss of the epithelial markers E-cadherin and Plakoglobin, and enhanced levels of the mesenchymal proteins Fibronectin, N-cadherin, and Vimentin (Fernando et al., 2010), (Fig. 14A). As a consequence of this phenotypic switch, human carcinoma cells undergoing Brachyury-mediated EMT acquire enhanced motility and the ability to invade (Fernando et al., 2010), (Fig. 14B). Xenograft experiments conducted in immunocompromised mice demonstrated that Brachyury expression does not affect the growth of the primary tumor. Inhibition of Brachyury, however, resulted in a significant impairment on the ability of tumor cells to disseminate from the subcutaneous tumor to the site of metastasis, and `a reduced ability to establish experimental lung metastasis after intravenous injection (Fig. 15).

Overexpression of Brachyury in human carcinoma cells has been shown to enhance resistance of tumor cells to chemotherapy and radiation, while silencing of Brachyury in tumor cells that naturally express high levels of this transcription factor has resulted in enhanced susceptibility to both types of therapeutics, in vitro (Fernando et al., 2010; Palena et al., 2013; Roselli et al., 2012).

It has been demonstrated that human $\mathrm{CD} 8^{+}$Brachyury-specific T-cells could be expanded in vitro from PBMCs of cancer patients and normal donors by using a 9-mer peptide of Brachyury that specifically binds to the HLA-A2 molecule (Palena et al., 2007). Brachyuryspecific T-cell lines have been shown to lyse carcinoma cells (Fernando et al., 2010; Roselli et al., 2012), (Fig. 16). Brachyury-specific T cells have also been expanded from the blood of cancer patients (Palena et al., 2007) and those T cells can lyse Brachyury-positive carcinoma cells in an MHC-restricted manner. A Phase I clinical study with a Brachyury vaccine is ongoing in patients with carcinomas, and future Phase II clinical studies employing Brachyury-based vaccines are anticipated.

The C-terminus of MUC1 has been shown by several groups to be extremely important in the initiation and progression of a range of human neoplasms. Overexpression of MUC1-C makes it possible for malignant cells of epithelial or hematopoietic origin to exploit this physiologic stress response, and thus stimulate their expansion and survival (Uchida et al., 2013). The MUC1-C oncoprotein has also been shown to induce tamoxifen and herceptin resistance in human breast tumor cells (Fessler et al., 2009; Kharbanda et al., 2013). MUC1$\mathrm{C}$-induced transcriptional programs have also been shown to be associated with tumorigenesis and predict a poor outcome in breast and lung cancer patients (Lacunza et al., 2010; MacDermed et al., 2010; Pitroda et al., 2009). The MUC1-C oncoprotein has also been shown to confer androgen-independent growth in human prostate cancer cells and to regulate survival of pancreatic cancer cells (Banerjee et al., 2012) and enhance invasiveness of pancreatic cancer cells by inducing EMT (Roy et al., 2011).

Seven novel CTL epitopes in the MUC1-C region of MUC1 have been identified recently along with enhancer agonists for each of these epitopes (Jochems, $\mathrm{C}$ et al., (in press)). This was demonstrated by the greater ability of the agonist peptide, compared to its 
corresponding native peptide, to generate MUC1-C-specific T-cell lines, enhance IFN- $\gamma$ production by $\mathrm{T}$ cells, and lyse human tumor cell targets endogenously expressing the native epitope in an MHC-restricted manner. T-cell lines were able to be generated from PBMCs of numerous cancer patients, employing the MUC1 agonist peptides. The MUC1-C agonist epitopes span class I MHC HLA-A2, -A3, and -A24, which encompass the majority of the population. The studies provide the rationale for immunotherapy clinical studies employing a range of vaccines that target Brachyury and/or the agonist epitopes of the C-terminus of MUC1 and thus target the biologically relevant processes of cancer cell progression and drug resistance.

\section{CONCLUDING REMARKS}

This chapter was designed to provide an overview of the progress in numerous different aspects of cancer vaccine design, development, and clinical application. It is anticipated that therapeutic cancer vaccines will eventually be employed in the management of numerous cancer types and stages, principally in the neoadjuvant and/or adjuvant settings, and in patients with evidence of, or the potential of, nominal residual metastatic disease. The low level of toxicity renders cancer vaccines ideal for combination therapies. Evidence is now mounting that, when used in appropriate scheduling regimens, cancer vaccines can be used in combination with certain chemotherapeutic agents, radiation, hormone therapy, and certain small molecule targeted therapeutics. Indeed, it is being shown that these "nonimmune"-based therapies can have an immune-enhancing component, by either altering the tumor cell to render it more susceptible to T-cell-mediated attack, lysing tumor cells in a manner to further enhance immunity, and/or altering the balance of immune effector cells over immune regulatory cells. As other non-vaccine immunotherapies, such as checkpoint inhibitors, are developed, they will undoubtedly be employed to enhance vaccine efficacy.

\section{References}

Aarts WM, Schlom J, Hodge JW. (2002). Vector-based vaccine/cytokine combination therapy to enhance induction of immune responses to a self-antigen and antitumor activity. Cancer Res 62, 5770-5777. [PubMed: 12384537]

Adotevi O, Pere H, Ravel P, Haicheur N, Badoual C, Merillon N, Medioni J, Peyrard S, Roncelin S, Verkarre V, Mejean A, Fridman WH, Oudard S, Tartour E. (2010). A decrease of regulatory T cells correlates with overall survival after sunitinib-based antiangiogenic therapy in metastatic renal cancer patients. J Immunother 33, 991-998. [PubMed: 20948437]

Allison JP, Chambers C, Hurwitz A, Sullivan T, Boitel B, Fournier S, Brunner M, Krummel M. (1998). A role for CTLA-4-mediated inhibitory signals in peripheral T cell tolerance? Novartis Found Symp 215, 92-98; discussion 98-102, 186-190. [PubMed: 9760573]

Andres A, Majno PE, Morel P, Rubbia-Brandt L, Giostra E, Gervaz P, Terraz S, Allal AS, Roth AD, Mentha G. (2008). Improved long-term outcome of surgery for advanced colorectal liver metastases: reasons and implications for management on the basis of a severity score. Ann Surg Oncol 15, 134143. [PubMed: 17909911]

Arlen PM, Gulley JL, Parker C, Skarupa L, Pazdur M, Panicali D, Beetham P, Tsang KY, Grosenbach DW, Feldman J, Steinberg SM, Jones E, Chen C, Marte J, Schlom J, Dahut W. (2006). A randomized phase II study of concurrent docetaxel plus vaccine versus vaccine alone in metastatic androgen-independent prostate cancer. Clin Cancer Res 12, 1260-1269. [PubMed: 16489082]

Arlen PM, Gulley JL, Todd N, Lieberman R, Steinberg SM, Morin S, Bastian A, Marte J, Tsang KY, Beetham P, Grosenbach DW, Schlom J, Dahut W. (2005). Antiandrogen, vaccine and combination 
therapy in patients with nonmetastatic hormone refractory prostate cancer. J Urol 174, 539-546. [PubMed: 16006888]

Arlen PM, Skarupa L, Pazdur M, Seetharam M, Tsang KY, Grosenbach DW, Feldman J, Poole DJ, Litzinger M, Steinberg SM, Jones E, Chen C, Marte J, Parnes H, Wright J, Dahut W, Schlom J, Gulley JL. (2007). Clinical safety of a viral vector based prostate cancer vaccine strategy. J Urol 178, 1515-1520. [PubMed: 17707059]

Arredouani MS, Tseng-Rogenski SS, Hollenbeck BK, Escara-Wilke J, Leander KR, Defeo-Jones D, Hwang C, Sanda MG. (2010). Androgen ablation augments human HLA2.1-restricted T cell responses to PSA self-antigen in transgenic mice. Prostate 70, 1002-1011. [PubMed: 20209643]

Arru M, Aldrighetti L, Castoldi R, Di Palo S, Orsenigo E, Stella M, Pulitano C, Gavazzi F, Ferla G, Di Carlo V, Staudacher C. (2008). Analysis of prognostic factors influencing long-term survival after hepatic resection for metastatic colorectal cancer. World J Surg 32, 93-103. [PubMed: 18027020]

Arumugam T, Ramachandran V, Fournier KF, Wang H, Marquis L, Abbruzzese JL, Gallick GE, Logsdon CD, McConkey DJ, Choi W. (2009). Epithelial to mesenchymal transition contributes to drug resistance in pancreatic cancer. Cancer Res 69, 5820-5828. [PubMed: 19584296]

Avigan D, Vasir B, Gong J, Borges V, Wu Z, Uhl L, Atkins M, Mier J, McDermott D, Smith T, Giallambardo N, Stone C, Schadt K, Dolgoff J, Tetreault JC, Villarroel M, Kufe D. (2004). Fusion cell vaccination of patients with metastatic breast and renal cancer induces immunological and clinical responses. Clin Cancer Res 10, 4699-4708. [PubMed: 15269142]

Banchereau J, Palucka AK, Dhodapkar M, Burkeholder S, Taquet N, Rolland A, Taquet S, Coquery S, Wittkowski KM, Bhardwaj N, Pineiro L, Steinman R, Fay J. (2001). Immune and clinical responses in patients with metastatic melanoma to CD34(+) progenitor-derived dendritic cell vaccine. Cancer Res 61, 6451-6458. [PubMed: 11522640]

Banchereau J, Steinman RM. (1998). Dendritic cells and the control of immunity. Nature 392, 245252. [PubMed: 9521319]

Banerjee S, Mujumdar N, Dudeja V, Mackenzie T, Krosch TK, Sangwan V, Vickers SM, Saluja AK. (2012). MUC1c regulates cell survival in pancreatic cancer by preventing lysosomal permeabilization. PLoS One 7, e43020. [PubMed: 22912777]

Beer T SS, Higano CS, al. e (2008). Phase I trial of ipilimumab (IPI) alone or in combination with radiotherapy (XRT) in patients with metastatic castration resistant prostate cancer (mCRPC). Proc Soc Am Clin Oncol 26 (suppl), abstr 5004.

Belardelli F, Ferrantini M, Parmiani G, Schlom J, Garaci E. (2004). International meeting on cancer vaccines: how can we enhance efficacy of therapeutic vaccines? Cancer Res 64, 6827-6830. [PubMed: 15375003]

Bendandi M (2009). Idiotype vaccines for lymphoma: proof-of-principles and clinical trial failures. Nat Rev Cancer 9, 675-681. [PubMed: 19701243]

Bilusic M, Gulley J, Heery C, et al. (2012). A randomized phase II study of flutamide with or without PSA-TRICOM in nonmetastatic castration-resistant prostate cancer. American Society of Clinical Oncology 2011 Genitourinary Symposium. J Clin Oncol 29: 2011 (suppl 7; abstr 163).

Boehm AL, Higgins J, Franzusoff A, Schlom J, Hodge JW. (2010). Concurrent vaccination with two distinct vaccine platforms targeting the same antigen generates phenotypically and functionally distinct T-cell populations. Cancer Immunol Immunother 59, 397-408. [PubMed: 19756595]

Bos R, van Duikeren S, Morreau H, Franken K, Schumacher TN, Haanen JB, van der Burg SH, Melief CJ, Offringa R. (2008). Balancing between antitumor efficacy and autoimmune pathology in Tcell-mediated targeting of carcinoembryonic antigen. Cancer Res 68, 8446-8455. [PubMed: 18922918]

Brichard VG, Lejeune D. (2008). Cancer immunotherapy targeting tumour-specific antigens: towards a new therapy for minimal residual disease. Expert Opin. Biol. Ther 8, 951-968. [PubMed: 18549325]

Butterfield LH, Palucka AK, Britten CM, Dhodapkar MV, Hakansson L, Janetzki S, Kawakami Y, Kleen TO, Lee PP, Maccalli C, Maecker HT, Maino VC, Maio M, Malyguine A, Masucci G, Pawelec G, Potter DM, Rivoltini L, Salazar LG, Schendel DJ, Slingluff CL, Jr., Song W, Stroncek DF, Tahara H, Thurin M, Trinchieri G, van Der Burg SH, Whiteside TL, Wigginton JM, Marincola 
F, Khleif S, Fox BA, Disis ML. (2011). Recommendations from the iSBTc-SITC/FDA/NCI Workshop on Immunotherapy Biomarkers. Clin Cancer Res 17, 3064-3076. [PubMed: 21558394]

Butts C, Murray N, Maksymiuk A, Goss G, Marshall E, Soulieres D, Cormier Y, Ellis P, Price A, Sawhney R, Davis M, Mansi J, Smith C, Vergidis D, MacNeil M, Palmer M. (2005). Randomized phase IIB trial of BLP25 liposome vaccine in stage IIIB and IV non-small-cell lung cancer. J Clin Oncol 23, 6674-6681. [PubMed: 16170175]

Carmeliet P, Jain RK. (2011). Principles and mechanisms of vessel normalization for cancer and other angiogenic diseases. Nat Rev Drug Discov 10, 417-427. [PubMed: 21629292]

Chakraborty M, Abrams SI, Coleman CN, Camphausen K, Schlom J, Hodge JW. (2004). External beam radiation of tumors alters phenotype of tumor cells to render them susceptible to vaccinemediated T-cell killing. Cancer Res 64, 4328-4337. [PubMed: 15205348]

Chakraborty M, Gelbard A, Carrasquillo JA, Yu S, Mamede M, Paik CH, Camphausen K, Schlom J, Hodge JW. (2008a). Use of radiolabeled monoclonal antibody to enhance vaccine-mediated antitumor effects. Cancer Immunol Immunother 57, 1173-1183. [PubMed: 18256832]

Chakraborty M, Wansley EK, Carrasquillo JA, Yu S, Paik CH, Camphausen K, Becker MD, Goeckeler WF, Schlom J, Hodge JW. (2008b). The use of chelated radionuclide (samarium-153ethylenediaminetetramethylenephosphonate) to modulate phenotype of tumor cells and enhance T cell-mediated killing. Clin Cancer Res 14, 4241-4249. [PubMed: 18594006]

Cham CM, Driessens G, O'Keefe JP, Gajewski TF. (2008). Glucose deprivation inhibits multiple key gene expression events and effector functions in CD8+ T cells. Eur J Immunol 38, 2438-2450. [PubMed: 18792400]

Cheever MA, Allison JP, Ferris AS, Finn OJ, Hastings BM, Hecht TT, Mellman I, Prindiville SA, Viner JL, Weiner LM, Matrisian LM. (2009). The prioritization of cancer antigens: a national cancer institute pilot project for the acceleration of translational research. Clin Cancer Res 15, 5323-5337. [PubMed: 19723653]

Choti MA, Sitzmann JV, Tiburi MF, Sumetchotimetha W, Rangsin R, Schulick RD, Lillemoe KD, Yeo CJ, Cameron JL. (2002). Trends in long-term survival following liver resection for hepatic colorectal metastases. Ann Surg 235, 759-766. [PubMed: 12035031]

Clarke P, Mann J, Simpson JF, Rickard-Dickson K, Primus FJ. (1998). Mice transgenic for human carcinoembryonic antigen as a model for immunotherapy. Cancer Res 58, 1469-1477. [PubMed: 9537250]

Derby M, Alexander-Miller M, Tse R, Berzofsky J. (2001). High-avidity CTL exploit two complementary mechanisms to provide better protection against viral infection than low-avidity CTL. J Immunol 166, 1690-1697. [PubMed: 11160212]

Dhodapkar KM, Feldman D, Matthews P, Radfar S, Pickering R, Turkula S, Zebroski H, Dhodapkar MV. (2010). Natural immunity to pluripotency antigen OCT4 in humans. Proc Natl Acad Sci U S A 107, 8718-8723. [PubMed: 20404147]

Dhodapkar MV, Dhodapkar KM. (2011). Spontaneous and therapy-induced immunity to pluripotency genes in humans: clinical implications, opportunities and challenges. Cancer Immunol Immunother 60, 413-418. [PubMed: 21104412]

DiPaola RS, Chen Y, Bubley GJ, Hahn NM, Stein M, Schlom J, Gulley JL, Lattime E, Carducci M, Wilding G. (2009). A phase II study of PROSTVAC-V (vaccinia)/TRICOM and PROSTVAC-F (fowlpox)/TRICOM with GM-CSF in patients with PSA progression after local therapy for prostate cancer: results of ECOG 9802. American Society of Clinical Oncology 2009 Genitourinary Cancers Symposium (abstr 108).

Disis ML. (2009). Enhancing cancer vaccine efficacy via modulation of the tumor microenvironment. Clin Cancer Res 15, 6476-6478. [PubMed: 19861446]

(2011). Immunologic biomarkers as correlates of clinical response to cancer immunotherapy. Cancer Immunol Immunother 60, 433-442. [PubMed: 21221967]

Dzutsev AH, Belyakov IM, Isakov DV, Margulies DH, Berzofsky JA. (2007). Avidity of CD8 T cells sharpens immunodominance. Int Immunol 19, 497-507. [PubMed: 17376783]

Egen JG, Kuhns MS, Allison JP. (2002). CTLA-4: new insights into its biological function and use in tumor immunotherapy. Nat Immunol 3, 611-618. [PubMed: 12087419] 
Emens LA, Asquith JM, Leatherman JM, Kobrin BJ, Petrik S, Laiko M, Levi J, Daphtary MM, Biedrzycki B, Wolff AC, Stearns V, Disis ML, Ye X, Piantadosi S, Fetting JH, Davidson NE, Jaffee EM. (2009). Timed sequential treatment with cyclophosphamide, doxorubicin, and an allogeneic granulocyte-macrophage colony-stimulating factor-secreting breast tumor vaccine: a chemotherapy dose-ranging factorial study of safety and immune activation. J Clin Oncol 27, 5911-5918. [PubMed: 19805669]

Farsaci B, Higgins JP, Hodge JW. (2012). Consequence of dose scheduling of sunitinib on host immune response elements and vaccine combination therapy. Int J Cancer 130, 1948-1959. [PubMed: 21633954]

Farsaci B, Sabzevari H, Higgins JP, Di Bari MG, Takai S, Schlom J, Hodge JW. (2010). Effect of a small molecule BCL-2 inhibitor on immune function and use with a recombinant vaccine. Int $\mathrm{J}$ Cancer 127, 1603-1613. [PubMed: 20091862]

Fernando RI, Litzinger M, Trono P, Hamilton DH, Schlom J, Palena C. (2010). The T-box transcription factor Brachyury promotes epithelial-mesenchymal transition in human tumor cells. J Clin Invest 120, 533-544. [PubMed: 20071775]

Fessler SP, Wotkowicz MT, Mahanta SK, Bamdad C. (2009). MUC1* is a determinant of trastuzumab (Herceptin) resistance in breast cancer cells. Breast Cancer Res Treat 118, 113-124. [PubMed: 19415485]

Finke JH, Rini B, Ireland J, Rayman P, Richmond A, Golshayan A, Wood L, Elson P, Garcia J, Dreicer R, Bukowski R. (2008). Sunitinib reverses type-1 immune suppression and decreases T-regulatory cells in renal cell carcinoma patients. Clin Cancer Res 14, 6674-6682. [PubMed: 18927310]

Finn OJ, Gantt KR, Lepisto AJ, Pejawar-Gaddy S, Xue J, Beatty PL. (2011). Importance of MUC1 and spontaneous mouse tumor models for understanding the immunobiology of human adenocarcinomas. Immunol Res 50, 261-268. [PubMed: 21717081]

Frazer IH, Lowy DR, Schiller JT. (2007). Prevention of cancer through immunization: Prospects and challenges for the 21st century. Eur J Immunol 37 Suppl 1, S148-155. [PubMed: 17972339]

Fridman WH, Pages F, Sautes-Fridman C, Galon J. (2012). The immune contexture in human tumours: impact on clinical outcome. Nat Rev Cancer 12, 298-306. [PubMed: 22419253]

Fukumura D, Duda DG, Munn LL, Jain RK. (2010). Tumor microvasculature and microenvironment: novel insights through intravital imaging in pre-clinical models. Microcirculation 17, 206-225. [PubMed: 20374484]

Gajewski TF, Meng Y, Blank C, Brown I, Kacha A, Kline J, Harlin H. (2006a). Immune resistance orchestrated by the tumor microenvironment. Immunol Rev 213, 131-145. [PubMed: 16972901]

Gajewski TF, Meng Y, Harlin H. (2006b). Immune suppression in the tumor microenvironment. J Immunother 29, 233-240. [PubMed: 16699366]

Galluzzi L, Senovilla L, Zitvogel L, Kroemer G. (2012). The secret ally: immunostimulation by anticancer drugs. Nat Rev Drug Discov 11, 215-233. [PubMed: 22301798]

Galon J, Pages F, Marincola FM, Thurin M, Trinchieri G, Fox BA, Gajewski TF, Ascierto PA. (2012). The immune score as a new possible approach for the classification of cancer. J Transl Med 10, 1. [PubMed: 22214470]

Garnett CT, Palena C, Chakraborty M, Tsang KY, Schlom J, Hodge JW. (2004). Sublethal irradiation of human tumor cells modulates phenotype resulting in enhanced killing by cytotoxic $\mathrm{T}$ lymphocytes. Cancer Res 64, 7985-7994. [PubMed: 15520206]

Garnett CT, Schlom J, Hodge JW. (2008). Combination of docetaxel and recombinant vaccine enhances T-cell responses and antitumor activity: effects of docetaxel on immune enhancement. Clin Cancer Res 14, 3536-3544. [PubMed: 18519787]

Gelbard A, Garnett CT, Abrams SI, Patel V, Gutkind JS, Palena C, Tsang KY, Schlom J, Hodge JW. (2006). Combination chemotherapy and radiation of human squamous cell carcinoma of the head and neck augments CTL-mediated lysis. Clin Cancer Res 12, 1897-1905. [PubMed: 16551875]

Gerritsen WR: CA184-043: A randomized, multicenter, double-blind phase 3 trial comparing overall survival (OS) in patients (pts) with post-docetaxel castration-resistant prostate cancer (CRPC) and bone metastases treated with ipilimumab (ipi) vs placebo (pbo), each following single-dose radiotherapy (RT) The European Cancer Congress, Sept. 27-Oct. 1, 2013 2013; abstr 2850. 
Gilewski TA, Ragupathi G, Dickler M, Powell S, Bhuta S, Panageas K, Koganty RR, Chin-Eng J, Hudis C, Norton L, Houghton AN, Livingston PO. (2007). Immunization of high-risk breast cancer patients with clustered sTn-KLH conjugate plus the immunologic adjuvant QS-21. Clin Cancer Res 13, 2977-2985. [PubMed: 17504999]

Gnjatic S, Old LJ, Chen YT. (2009a). Autoantibodies against cancer antigens. Methods Mol Biol 520, 11-19. [PubMed: 19381944]

Gnjatic S, Ritter E, Buchler MW, Giese NA, Brors B, Frei C, Murray A, Halama N, Zornig I, Chen YT, Andrews C, Ritter G, Old LJ, Odunsi K, Jager D. (2010). Seromic profiling of ovarian and pancreatic cancer. Proc Natl Acad Sci U S A 107, 5088-5093. [PubMed: 20194765]

Gnjatic S, Wheeler C, Ebner M, Ritter E, Murray A, Altorki NK, Ferrara CA, Hepburne-Scott H, Joyce S, Koopman J, McAndrew MB, Workman N, Ritter G, Fallon R, Old LJ. (2009b). Seromic analysis of antibody responses in non-small cell lung cancer patients and healthy donors using conformational protein arrays. J Immunol Methods 341, 50-58. [PubMed: 19041653]

Greiner JW, Zeytin H, Anver MR, Schlom J. (2002). Vaccine-based therapy directed against carcinoembryonic antigen demonstrates antitumor activity on spontaneous intestinal tumors in the absence of autoimmunity. Cancer Res 62, 6944-6951. [PubMed: 12460911]

Grosenbach DW, Barrientos JC, Schlom J, Hodge JW. (2001). Synergy of vaccine strategies to amplify antigen-specific immune responses and antitumor effects. Cancer Res 61, 4497-4505. [PubMed: $11389081]$

Gulley JL. (2013). Therapeutic vaccines: the ultimate personalized therapy? Hum Vaccin Immunother 9, 219-221. [PubMed: 22995839]

Gulley JL, Arlen PM, Bastian A, Morin S, Marte J, Beetham P, Tsang KY, Yokokawa J, Hodge JW, Menard C, Camphausen K, Coleman CN, Sullivan F, Steinberg SM, Schlom J, Dahut W. (2005). Combining a recombinant cancer vaccine with standard definitive radiotherapy in patients with localized prostate cancer. Clin Cancer Res 11, 3353-3362. [PubMed: 15867235]

Gulley JL, Arlen PM, Hodge JW, Schlom J. (2010a). Vaccines and immunostimulants. In: Kufe D (Ed.). Holland-Frei Cancer Medicine, 8th Edition (Chapter 57, pp. 725-736). Shelton, CT: People's Medical Publishing House-USA.

Gulley JL, Arlen PM, Madan RA, Tsang KY, Pazdur MP, Skarupa L, Jones JL, Poole DJ, Higgins JP, Hodge JW, Cereda V, Vergati M, Steinberg SM, Halabi S, Jones E, Chen C, Parnes H, Wright JJ, Dahut WL, Schlom J. (2010b). Immunologic and prognostic factors associated with overall survival employing a poxviral-based PSA vaccine in metastatic castrate-resistant prostate cancer. Cancer Immunol Immunother 59, 663-674. [PubMed: 19890632]

Gulley JL, Arlen PM, Tsang KY, Yokokawa J, Palena C, Poole DJ, Remondo C, Cereda V, Jones JL, Pazdur MP, Higgins JP, Hodge JW, Steinberg SM, Kotz H, Dahut WL, Schlom J. (2008). Pilot study of vaccination with recombinant CEA-MUC-1-TRICOM poxviral-based vaccines in patients with metastatic carcinoma. Clin Cancer Res 14, 3060-3069. [PubMed: 18483372]

Gulley JL, Madan RA, Schlom J. (2011). The impact of tumour volume on potential efficacy of therapeutic vaccines [review]. Curr Oncol 18, e150-e157. [PubMed: 21655153]

Halabi S, Small EJ, Kantoff PW, Kattan MW, Kaplan EB, Dawson NA, Levine EG, Blumenstein BA, Vogelzang NJ. (2003). Prognostic model for predicting survival in men with hormone-refractory metastatic prostate cancer. J Clin Oncol 21, 1232-1237. [PubMed: 12663709]

Hardwick N, Chain B. (2011). Epitope spreading contributes to effective immunotherapy in metastatic melanoma patients. Immunotherapy 3, 731-733. [PubMed: 21668310]

Heery CR, Madan RA, Bilusic M, Kim JW, Singh NK, Rauckhorst M, Steinberg SM, Dahut WL, Chen C, DiPaola RS, Stein MN, Panicali D, Hodge JW, Schlom J, Gulley JL. (2013). A phase II randomized clinical trial of samarium-153 EDTMP (Sm-153) with or without PSA-tricom vaccine in metastatic castration-resistant prostate cancer (mCRPC) after docetaxel. ASCO Genitourinary Cancers Symposium, Feb. 14-16, 2013, Orlando, FL. J. Clin. Oncol 31 (suppl 6; abstr 102).

Higano CS, Schellhammer PF, Small EJ, Burch PA, Nemunaitis J, Yuh L, Provost N, Frohlich MW. (2009). Integrated data from 2 randomized, double-blind, placebo-controlled, phase 3 trials of active cellular immunotherapy with sipuleucel-T in advanced prostate cancer. Cancer 115, 36703679. [PubMed: 19536890] 
Hodge JW, Chakraborty M, Kudo-Saito C, Garnett CT, Schlom J. (2005). Multiple costimulatory modalities enhance CTL avidity. J Immunol 174, 5994-6004. [PubMed: 15879092]

Hodge JW, Grosenbach DW, Aarts WM, Poole DJ, Schlom J. (2003a). Vaccine therapy of established tumors in the absence of autoimmunity. Clin Cancer Res 9, 1837-1849. [PubMed: 12738742]

Hodge JW, Higgins J, Schlom J. (2009). Harnessing the unique local immunostimulatory properties of modified vaccinia Ankara (MVA) virus to generate superior tumor-specific immune responses and antitumor activity in a diversified prime and boost vaccine regimen. Vaccine 27, 4475-4482. [PubMed: 19450631]

Hodge JW, McLaughlin JP, Abrams SI, Shupert WL, Schlom J, Kantor JA. (1995). Admixture of a recombinant vaccinia virus containing the gene for the costimulatory molecule B7 and a recombinant vaccinia virus containing a tumor-associated antigen gene results in enhanced specific T-cell responses and antitumor immunity. Cancer Res 55, 3598-3603. [PubMed: 7543017]

Hodge JW, Poole DJ, Aarts WM, Gomez Yafal A, Gritz L, Schlom J. (2003b). Modified vaccinia virus ankara recombinants are as potent as vaccinia recombinants in diversified prime and boost vaccine regimens to elicit therapeutic antitumor responses. Cancer Res 63, 7942-7949. [PubMed: 14633725]

Hodi FS, O’Day SJ, McDermott DF, Weber RW, Sosman JA, Haanen JB, Gonzalez R, Robert C, Schadendorf D, Hassel JC, Akerley W, van den Eertwegh AJ, Lutzky J, Lorigan P, Vaubel JM, Linette GP, Hogg D, Ottensmeier CH, Lebbe C, Peschel C, Quirt I, Clark JI, Wolchok JD, Weber JS, Tian J, Yellin MJ, Nichol GM, Hoos A, Urba WJ. (2010). Improved survival with ipilimumab in patients with metastatic melanoma. N Engl J Med 363, 711-723. [PubMed: 20525992]

Hoos A, Eggermont AM, Janetzki S, Hodi FS, Ibrahim R, Anderson A, Humphrey R, Blumenstein B, Old L, Wolchok J. (2010). Improved endpoints for cancer immunotherapy trials. J Natl Cancer Inst 102, 1388-1397. [PubMed: 20826737]

Hoover HC, Jr., Brandhorst JS, Peters LC, Surdyke MG, Takeshita Y, Madariaga J, Muenz LR, Hanna MG, Jr., (1993). Adjuvant active specific immunotherapy for human colorectal cancer: 6.5-year median follow-up of a phase III prospectively randomized trial. J Clin Oncol 11, 390-399. [PubMed: 8445413]

House MG, Ito H, Gonen M, Fong Y, Allen PJ, DeMatteo RP, Brennan MF, Blumgart LH, Jarnagin WR, D'Angelica MI. (2010). Survival after hepatic resection for metastatic colorectal cancer: trends in outcomes for 1,600 patients during two decades at a single institution. J Am Coll Surg 210, 744-752, 752-745. [PubMed: 20421043]

Hua W, Yao Y, Chu Y, Zhong P, Sheng X, Xiao B, Wu J, Yang B, Mao Y, Zhou L. (2011 411 [Epub]). The CD133+ tumor stem-like cell-associated antigen may elicit highly intense immune responses against human malignant glioma. J Neurooncol

Inoges S, Rodriguez-Calvillo M, Zabalegui N, Lopez-Diaz de Cerio A, Villanueva H, Soria E, Suarez L, Rodriguez-Caballero A, Pastor F, Garcia-Munoz R, Panizo C, Perez-Calvo J, Melero I, Rocha E, Orfao A, Bendandi M. (2006). Clinical benefit associated with idiotypic vaccination in patients with follicular lymphoma. J Natl Cancer Inst 98, 1292-1301. [PubMed: 16985248]

Irvine K, Kantor J, Schlom J. (1993). Comparison of a CEA-recombinant vaccinia virus, purified CEA, and an anti-idiotypic antibody bearing the image of a CEA epitope in the treatment and prevention of CEA-expressing tumors. Vaccine Res 2, 79-94.

Jochems C, Schlom J. (2011). Tumor-infiltrating immune cells and prognosis: the potential link between conventional cancer therapy and immunity. Exp Biol Med (Maywood) 236, 567-579. [PubMed: 21486861]

Jochems C, Tucker J, Vergati M, B. B, J.L. G, J S, K-Y T ((in press)). Identification and characterization of agonist epitopes of the MUC1-C oncoprotein. Cancer Immunol Immunother

Kalluri R, Weinberg RA. (2009). The basics of epithelial-mesenchymal transition. J Clin Invest 119, 1420-1428. doi: 1410.1172/JCI39104. [PubMed: 19487818]

Kalus RM, Kantor JA, Gritz L, Gomez Yafal A, Mazzara GP, Schlom J, Hodge JW. (1999). The use of combination vaccinia vaccines and dual-gene vaccinia vaccines to enhance antigen-specific T-cell immunity via T-cell costimulation. Vaccine 17, 893-903. [PubMed: 10067696]

Kantoff PW, Higano CS, Shore ND, Berger ER, Small EJ, Penson DF, Redfern CH, Ferrari AC, Dreicer R, Sims RB, Xu Y, Frohlich MW, Schellhammer PF. (2010a). Sipuleucel-T 
immunotherapy for castration-resistant prostate cancer. New Eng J Med 363, 411-422. [PubMed: 20818862]

Kantoff PW, Schuetz TJ, Blumenstein BA, Glode LM, Bilhartz DL, Wyand M, Manson K, Panicali DL, Laus R, Schlom J, Dahut WL, Arlen PM, Gulley JL, Godfrey WR. (2010b). Overall survival analysis of a phase II randomized controlled trial of a Poxviral-based PSA-targeted immunotherapy in metastatic castration-resistant prostate cancer. J Clin Oncol 28, 1099-1105. [PubMed: 20100959]

Kaplan CD, Kruger JA, Zhou H, Luo Y, Xiang R, Reisfeld RA. (2006). A novel DNA vaccine encoding PDGFRbeta suppresses growth and dissemination of murine colon, lung and breast carcinoma. Vaccine 24, 6994-7002. [PubMed: 17050049]

Karbach J, Neumann A, Atmaca A, Wahle C, Brand K, von Boehmer L, Knuth A, Bender A, Ritter G, Old LJ, Jager E. (2011). Efficient in vivo priming by vaccination with recombinant NY-ESO-1 protein and $\mathrm{CpG}$ in antigen naive prostate cancer patients. Clin Cancer Res 17, 861-870. [PubMed: 21163871]

Kass E, Schlom J, Thompson J, Guadagni F, Graziano P, Greiner JW. (1999). Induction of protective host immunity to carcinoembryonic antigen (CEA), a self-antigen in CEA transgenic mice, by immunizing with a recombinant vaccinia-CEA virus. Cancer Res 59, 676-683. [PubMed: 9973217]

Kaufman HL, Wang W, Manola J, DiPaola RS, Ko YJ, Sweeney C, Whiteside TL, Schlom J, Wilding G, Weiner LM. (2004). Phase II randomized study of vaccine treatment of advanced prostate cancer (E7897): a trial of the Eastern Cooperative Oncology Group. J Clin Oncol 22, 2122-2132. [PubMed: 15169798]

Kemp TJ, Garcia-Pineres A, Falk RT, Poncelet S, Dessy F, Giannini SL, Rodriguez AC, Porras C, Herrero R, Hildesheim A, Pinto LA. (2008). Evaluation of systemic and mucosal anti-HPV16 and anti-HPV18 antibody responses from vaccinated women. Vaccine 26, 3608-3616. [PubMed: 18541349]

Kemp TJ, Hildesheim A, Safaeian M, Dauner JG, Pan Y, Porras C, Schiller JT, Lowy DR, Herrero R, Pinto LA. (2011). HPV16/18 L1 VLP vaccine induces cross-neutralizing antibodies that may mediate cross-protection. Vaccine 29, 2011-2014. [PubMed: 21241731]

Kepp O, Galluzzi L, Martins I, Schlemmer F, Adjemian S, Michaud M, Sukkurwala AQ, Menger L, Zitvogel L, Kroemer G. (2011). Molecular determinants of immunogenic cell death elicited by anticancer chemotherapy. Cancer Metastasis Rev 30, 61-69. [PubMed: 21249425]

Kharbanda A, Rajabi H, Jin C, Raina D, Kufe D. (2013). MUC1-C oncoprotein induces tamoxifen resistance in human breast cancer cells. Mol Cancer Res

Kim PS, Ahmed R. (2010). Features of responding T cells in cancer and chronic infection. Curr Opin Immunol 22, 223-230. [PubMed: 20207527]

Ko JS, Rayman P, Ireland J, Swaidani S, Li G, Bunting KD, Rini B, Finke JH, Cohen PA. (2010). Direct and differential suppression of myeloid-derived suppressor cell subsets by sunitinib is compartmentally constrained. Cancer Res 70, 3526-3536. [PubMed: 20406969]

Ko JS, Zea AH, Rini BI, Ireland JL, Elson P, Cohen P, Golshayan A, Rayman PA, Wood L, Garcia J, Dreicer R, Bukowski R, Finke JH. (2009). Sunitinib mediates reversal of myeloid-derived suppressor cell accumulation in renal cell carcinoma patients. Clin Cancer Res 15, 2148-2157. [PubMed: 19276286]

Kodumudi KN, Woan K, Gilvary DL, Sahakian E, Wei S, Djeu JY. (2010). A novel chemoimmunomodulating property of docetaxel: suppression of myeloid-derived suppressor cells in tumor bearers. Clin Cancer Res 16, 4583-4594. [PubMed: 20702612]

Kudo-Saito C, Garnett CT, Wansley EK, Schlom J, Hodge JW. (2007). Intratumoral delivery of vector mediated IL-2 in combination with vaccine results in enhanced T cell avidity and anti-tumor activity. Cancer Immunol Immunother 56, 1897-1910. [PubMed: 17503041]

Kudo-Saito C, Hodge JW, Kwak H, Kim-Schulze S, Schlom J, Kaufman HL. (2006). 4-1BB ligand enhances tumor-specific immunity of poxvirus vaccines. Vaccine 24, 4975-4986. [PubMed: 16621183] 
Kudo-Saito C, Schlom J, Camphausen K, Coleman CN, Hodge JW. (2005a). The requirement of multimodal therapy (vaccine, local tumor radiation, and reduction of suppressor cells) to eliminate established tumors. Clin Cancer Res 11, 4533-4544. [PubMed: 15958639]

Kudo-Saito C, Schlom J, Hodge JW. (2005b). Induction of an antigen cascade by diversified subcutaneous/intratumoral vaccination is associated with antitumor responses. Clin Cancer Res 11, 2416-2426. [PubMed: 15788693]

Kufe DW. (2009). Mucins in cancer: function, prognosis and therapy. Nat Rev Cancer 9, 874-885. [PubMed: 19935676]

Kurrey NK, Jalgaonkar SP, Joglekar AV, Ghanate AD, Chaskar PD, Doiphode RY, Bapat SA. (2009). Snail and slug mediate radioresistance and chemoresistance by antagonizing p53-mediated apoptosis and acquiring a stem-like phenotype in ovarian cancer cells. Stem Cells 27, 20592068. [PubMed: 19544473]

Lacunza E, Baudis M, Colussi AG, Segal-Eiras A, Croce MV, Abba MC. (2010). MUC1 oncogene amplification correlates with protein overexpression in invasive breast carcinoma cells. Cancer Genet Cytogenet 201, 102-110. [PubMed: 20682394]

Laheru D, Lutz E, Burke J, Biedrzycki B, Solt S, Onners B, Tartakovsky I, Nemunaitis J, Le D, Sugar E, Hege K, Jaffee E. (2008). Allogeneic granulocyte macrophage colony-stimulating factorsecreting tumor immunotherapy alone or in sequence with cyclophosphamide for metastatic pancreatic cancer: a pilot study of safety, feasibility, and immune activation. Clin Cancer Res 14, 1455-1463. [PubMed: 18316569]

Larocca C, Schlom J. (2011). Viral vector-based therapeutic cancer vaccines. Cancer J 17, 359-371. [PubMed: 21952287]

Lee DK, Hakim FT, Gress RE. (2010). The thymus and the immune system: layered levels of control. J Thorac Oncol 5, S273-276. [PubMed: 20859118]

Locher C, Conforti R, Aymeric L, Ma Y, Yamazaki T, Rusakiewicz S, Tesniere A, Ghiringhelli F, Apetoh L, Morel Y, Girard JP, Kroemer G, Zitvogel L. (2010). Desirable cell death during anticancer chemotherapy. Ann N Y Acad Sci 1209, 99-108. [PubMed: 20958322]

Lorenz MG, Kantor JA, Schlom J, Hodge JW. (1999a). Anti-tumor immunity elicited by a recombinant vaccinia virus expressing CD70 (CD27L). Hum Gene Ther 10, 1095-1103. [PubMed: 10340542]

Lorenz MG, Kantor JA, Schlom J, Hodge JW. (1999b). Induction of anti-tumor immunity elicited by tumor cells expressing a murine LFA-3 analog via a recombinant vaccinia virus. Hum Gene Ther 10, 623-631. [PubMed: 10094205]

Luiten RM, Kueter EW, Mooi W, Gallee MP, Rankin EM, Gerritsen WR, Clift SM, Nooijen WJ, Weder P, van de Kasteele WF, Sein J, van den Berk PC, Nieweg OE, Berns AM, Spits H, de Gast GC. (2005). Immunogenicity, including vitiligo, and feasibility of vaccination with autologous GM-CSF-transduced tumor cells in metastatic melanoma patients. J Clin Oncol 23, 8978-8991. [PubMed: 16260696]

Lutz E, Yeo CJ, Lillemoe KD, Biedrzycki B, Kobrin B, Herman J, Sugar E, Piantadosi S, Cameron JL, Solt S, Onners B, Tartakovsky I, Choi M, Sharma R, Illei PB, Hruban RH, Abrams RA, Le D, Jaffee E, Laheru D. (2011). A lethally irradiated allogeneic granulocyte-macrophage colony stimulating factor-secreting tumor vaccine for pancreatic adenocarcinoma. A Phase II trial of safety, efficacy, and immune activation. Ann Surg 253, 328-335. [PubMed: 21217520]

MacDermed DM, Khodarev NN, Pitroda SP, Edwards DC, Pelizzari CA, Huang L, Kufe DW, Weichselbaum RR. (2010). MUC1-associated proliferation signature predicts outcomes in lung adenocarcinoma patients. BMC Med Genomics 3, 16. [PubMed: 20459602]

MacDonald GH, Johnston RE. (2000). Role of dendritic cell targeting in Venezuelan equine encephalitis virus pathogenesis. J Virol 74, 914-922. [PubMed: 10623754]

Madan RA, Gulley JL, Fojo T, Dahut WL. (2010a). Therapeutic cancer vaccines in prostate cancer: the paradox of improved survival without changes in time to progression. Oncologist 15, 969-975. [PubMed: 20798195]

Madan RA, Gulley JL, Schlom J, Steinberg SM, Liewehr DJ, Dahut WL, Arlen PM. (2008). Analysis of overall survival in patients with nonmetastatic castration-resistant prostate cancer treated with vaccine, nilutamide, and combination therapy. Clin Cancer Res 14, 4526-4531. [PubMed: 18628467] 
Madan RA, Mohebtash M, Arlen PM, Vergati M, Rauckhorst M, Steinberg SM, Tsang KY, Poole DJ, Parnes HL, Wright JJ, Dahut WL, Schlom J, Gulley JL. (2012). Ipilimumab and a poxviral vaccine targeting prostate-specific antigen in metastatic castration-resistant prostate cancer: a phase 1 dose-escalation trial. Lancet Oncol 13, 501-508. [PubMed: 22326924]

Madan RA, Mohebtash M, Schlom J, Gulley JL. (2010b). Therapeutic vaccines in metastatic castration-resistant prostate cancer: principles in clinical trial design. Expert Opin Biol Ther 10, 19-28. [PubMed: 19857185]

Marshall JL, Gulley JL, Arlen PM, Beetham PK, Tsang KY, Slack R, Hodge JW, Doren S, Grosenbach DW, Hwang J, Fox E, Odogwu L, Park S, Panicali D, Schlom J. (2005). Phase I study of sequential vaccinations with fowlpox-CEA(6D)-TRICOM alone and sequentially with vacciniaCEA(6D)-TRICOM, with and without granulocyte-macrophage colony-stimulating factor, in patients with carcinoembryonic antigen-expressing carcinomas. J Clin Oncol 23, 720-731. [PubMed: 15613691]

Marshall JL, Hoyer RJ, Toomey MA, Faraguna K, Chang P, Richmond E, Pedicano JE, Gehan E, Peck RA, Arlen P, Tsang KY, Schlom J. (2000). Phase I study in advanced cancer patients of a diversified prime-and-boost vaccination protocol using recombinant vaccinia virus and recombinant nonreplicating avipox virus to elicit anti-carcinoembryonic antigen immune responses. J Clin Oncol 18, 3964-3973. [PubMed: 11099326]

Mine T, Matsueda S, Li Y, Tokumitsu H, Gao H, Danes C, Wong KK, Wang X, Ferrone S, Ioannides CG. (2009). Breast cancer cells expressing stem cell markers CD44+ CD24 lo are eliminated by Numb-1 peptide-activated T cells. Cancer Immunol Immunother 58, 1185-1194. [PubMed: 19048252]

Mohebtash M, Tsang KY, Madan RA, Huen NY, Poole DJ, Jochems C, Jones J, Ferrara T, Heery CR, Arlen PM, Steinberg SM, Pazdur M, Rauckhorst M, Jones EC, Dahut WL, Schlom J, Gulley JL. (2011). A pilot study of MUC-1/CEA/TRICOM poxviral-based vaccine in patients with metastatic breast and ovarian cancer. Clin Cancer Res 17, 7164-7173. [PubMed: 22068656]

Morse MA, Chaudhry A, Gabitzsch ES, Hobeika AC, Osada T, Clay TM, Amalfitano A, Burnett BK, Devi GR, Hsu DS, Xu Y, Balcaitis S, Dua R, Nguyen S, Balint JP, Jr., Jones FR, Lyerly HK (2013a). Novel adenoviral vector induces T-cell responses despite anti-adenoviral neutralizing antibodies in colorectal cancer patients. Cancer Immunol Immunother 62, 1293-1301. [PubMed: 23624851]

Morse MA, Niedzwiecki D, Marshall JL, Garrett C, Chang DZ, Aklilu M, Crocenzi TS, Cole DJ, Dessureault S, Hobeika AC, Osada T, Onaitis M, Clary BM, Hsu D, Devi GR, Bulusu A, Annechiarico RP, Chadaram V, Clay TM, Lyerly HK. (2013b). A Randomized Phase II Study of Immunization With Dendritic Cells Modified With Poxvectors Encoding CEA and MUC1 Compared With the Same Poxvectors Plus GM-CSF for Resected Metastatic Colorectal Cancer. Ann Surg

Moss B (1996). Genetically engineered poxviruses for recombinant gene expression, vaccination, and safety. Proc Natl Acad Sci U S A 93, 11341-11348. [PubMed: 8876137]

Mueller SN, Ahmed R. (2009). High antigen levels are the cause of T cell exhaustion during chronic viral infection. Proc Natl Acad Sci U S A 106, 8623-8628. [PubMed: 19433785]

Nakaya HI, Wrammert J, Lee EK, Racioppi L, Marie-Kunze S, Haining WN, Means AR, Kasturi SP, Khan N, Li GM, McCausland M, Kanchan V, Kokko KE, Li S, Elbein R, Mehta AK, Aderem A, Subbarao K, Ahmed R, Pulendran B. (2011). Systems biology of vaccination for seasonal influenza in humans. Nat Immunol 12, 786-795. [PubMed: 21743478]

NCT01867333. Enzalutamide with or without vaccine therapy for advanced prostate cancer http:// www.clinicaltrials.gov/ct2/show/NCT01867333?term=NCT01867333\&rank=1.

NCT01875250. Enzalutamide in combination with PSA-TRICOM in patients with non-metastatic castration sensitive prostate cancer http://www.clinicaltrials.gov/ct2/show/NCT01875250? term $=$ NCT01875250\&rank $=1$.

Oh S, Hodge JW, Ahlers JD, Burke DS, Schlom J, Berzofsky JA. (2003). Selective induction of high avidity CTL by altering the balance of signals from APC. J Immunol 170, 2523-2530. [PubMed: 12594278]

Okada H, Kalinski P, Ueda R, Hoji A, Kohanbash G, Donegan TE, Mintz AH, Engh JA, Bartlett DL, Brown CK, Zeh H, Holtzman MP, Reinhart TA, Whiteside TL, Butterfield LH, Hamilton RL, 
Potter DM, Pollack IF, Salazar AM, Lieberman FS. (2011). Induction of CD8+ T-cell responses against novel glioma-associated antigen peptides and clinical activity by vaccinations with \{alpha\}-type 1 polarized dendritic cells and polyinosinic-polycytidylic acid stabilized by lysine and carboxymethylcellulose in patients with recurrent malignant glioma. J Clin Oncol 29, 330336. [PubMed: 21149657]

Okur FV, Yvon E, Biagi E, Dotti G, Carrum G, Heslop H, Mims MP, Fratantoni JC, Peshwa MV, Li L, Brenner MK. (2011 7 12). Comparison of two CD40-ligand/interleukin-2 vaccines in patients with chronic lymphocytic leukemia. Cytotherapy

Osada T, Yang XY, Hartman ZC, Glass O, Hodges BL, Niedzwiecki D, Morse MA, Lyerly HK, Amalfitano A, Clay TM. (2009). Optimization of vaccine responses with an E1, E2b and E3deleted Ad5 vector circumvents pre-existing anti-vector immunity. Cancer Gene Ther 16, 673682. [PubMed: 19229288]

Palena C, Polev DE, Tsang KY, Fernando RI, Litzinger M, Krukovskaya LL, Baranova AV, Kozlov AP, Schlom J. (2007). The human T-box mesodermal transcription factor Brachyury is a candidate target for T-cell-mediated cancer immunotherapy. Clin Cancer Res 13, 2471-2478. [PubMed: 17438107]

Palena C, Schlom J. (2013). Target: Brachyury, a master driver of epithelial-to-mesenchymal transition (EMT). Encyclopedia of Cancer Therapeutic Targets

Parkhurst MR, Yang JC, Langan RC, Dudley ME, Nathan DA, Feldman SA, Davis JL, Morgan RA, Merino MJ, Sherry RM, Hughes MS, Kammula US, Phan GQ, Lim RM, Wank SA, Restifo NP, Robbins PF, Laurencot CM, Rosenberg SA. (2011). T cells targeting carcinoembryonic antigen can mediate regression of metastatic colorectal cancer but induce severe transient colitis. Mol Ther 19, 620-626. [PubMed: 21157437]

Pawlik TM, Scoggins CR, Zorzi D, Abdalla EK, Andres A, Eng C, Curley SA, Loyer EM, Muratore A, Mentha G, Capussotti L, Vauthey JN. (2005). Effect of surgical margin status on survival and site of recurrence after hepatic resection for colorectal metastases. Ann Surg 241, 715-722, discussion 722-714. [PubMed: 15849507]

Pejawar-Gaddy S, Rajawat Y, Hilioti Z, Xue J, Gaddy DF, Finn OJ, Viscidi RP, Bossis I. (2010). Generation of a tumor vaccine candidate based on conjugation of a MUC1 peptide to polyionic papillomavirus virus-like particles. Cancer Immunol Immunother 59, 1685-1696. [PubMed: 20652244]

Pitroda SP, Khodarev NN, Beckett MA, Kufe DW, Weichselbaum RR. (2009). MUC1-induced alterations in a lipid metabolic gene network predict response of human breast cancers to tamoxifen treatment. Proc Natl Acad Sci U S A 106, 5837-5841. [PubMed: 19289846]

Polyak K, Weinberg RA. (2009). Transitions between epithelial and mesenchymal states: acquisition of malignant and stem cell traits. Nat Rev Cancer 9, 265-273. [PubMed: 19262571]

Pound CR, Partin AW, Eisenberger MA, Chan DW, Pearson JD, Walsh PC. (1999). Natural history of progression after PSA elevation following radical prostatectomy. JAMA 281, 1591-1597. [PubMed: 10235151]

Ragupathi G, Damani P, Srivastava G, Srivastava O, Sucheck SJ, Ichikawa Y, Livingston PO. (2009). Synthesis of sialyl Lewis(a) (sLe (a), CA19-9) and construction of an immunogenic sLe(a) vaccine. Cancer Immunol Immunother 58, 1397-1405. [PubMed: 19190907]

Raina D, Kosugi M, Ahmad R, Panchamoorthy G, Rajabi H, Alam M, Shimamura T, Shapiro GI, Supko J, Kharbanda S, Kufe D. (2011). Dependence on the MUC1-C oncoprotein in non-small cell lung cancer cells. Mol Cancer Ther 10, 806-816. [PubMed: 21421804]

Remondo C, Cereda V, Mostbock S, Sabzevari H, Franzusoff A, Schlom J, Tsang KY. (2009). Human dendritic cell maturation and activation by a heat-killed recombinant yeast (Saccharomyces cerevisiae) vector encoding carcinoembryonic antigen. Vaccine 27, 987-994. [PubMed: 19110021]

Rojan A, Funches R, Regan MM, Gulley JL, Bubley GJ. (2013). Dramatic and Prolonged PSA Response After Retreatment With a PSA Vaccine. Clin Genitourin Cancer 11, 362-364. [PubMed: 23791437]

Roselli M, Cereda V, di Bari M, Formica V, Spila A, Jochems C, Farsaci B, Donahue R, Gulley J, Schlom J, Guadagni F. (in press). The effect of nonimmune therapeutic interventions on regulatory T-cell number and function. OncoImmunology Epub: 11.1.13. 
Roselli M, Fernando RI, Guadagni F, Spila A, Alessandroni J, Palmirotta R, Costarelli L, Litzinger M, Hamilton D, Huang B, Tucker J, Tsang KY, Schlom J, Palena C. (2012). Brachyury, a driver of the epithelial-mesenchymal transition, is overexpressed in human lung tumors: an opportunity for novel interventions against lung cancer. Clin Cancer Res 18, 3868-3879. [PubMed: 22611028]

Roy LD, Sahraei M, Subramani DB, Besmer D, Nath S, Tinder TL, Bajaj E, Shanmugam K, Lee YY, Hwang SI, Gendler SJ, Mukherjee P. (2011). MUC1 enhances invasiveness of pancreatic cancer cells by inducing epithelial to mesenchymal transition. Oncogene 30, 1449-1459. [PubMed: 21102519]

Salazar LG, Wallace D, Mukherjee P, Higgins D, Childs J, Bates N, Coveler AL, Disis ML. (2009). HER-2/neu (HER2) specific T-cell immunity in patients with HER2+ inflammatory breast cancer (IBC) and prognosis. American Society of Clinical Oncology 2009 Annual Meeting. J Clin Oncol 27:15s, 2009 (suppl; abstr 3057).

Sanda MG, Smith DC, Charles LG, Hwang C, Pienta KJ, Schlom J, Milenic D, Panicali D, Montie JE. (1999). Recombinant vaccinia-PSA (PROSTVAC) can induce a prostate-specific immune response in androgen-modulated human prostate cancer. Urology 53, 260-266. [PubMed: 9933036]

Sasaki A, Iwashita Y, Shibata K, Matsumoto T, Ohta M, Kitano S. (2005). Analysis of preoperative prognostic factors for long-term survival after hepatic resection of liver metastasis of colorectal carcinoma. J Gastrointest Surg 9, 374-380. [PubMed: 15749600]

Schlom J (2012). Therapeutic cancer vaccines: current status and moving forward. J Natl Cancer Inst 104, 599-613. [PubMed: 22395641]

Schlom J, Hodge J, Palena C, Greiner J, Tsang K-Y, Farsaci B, Madan R, Gulley J. (2013a). Recombinant TRICOM-based therapeutic cancer vaccines: lessons learned. In: Prendergast G, Jaffee E (Eds.), Cancer Immunotherapy: Immune Suppression and Tumor Growth, Second Edition (Chapter 20, pp. 309-331). Elsevier Ltd.

Schlom J, Palena C, Gulley J, Greiner J, Tsang K-Y, Madan R, Hodge J. (2013b). The use of T-cell costimulation to enhance the immunogenicity of tumors. In: Lattime E, Gerson S Gene Therapy of Cancer, Third Edition (Chapter 22, pp. 315-334). Elsevier.

Schlom J, Tsang KY, Hodge JW, Greiner JW. (2001). Carcinoembryonic antigen as a vaccine target. In: Rees RC, Robins A Cancer Immunology: Immunology in Medicine Series (pp. 73-100). Norwell, MA: Kluwer Academic Publishers.

Schuster SJ, Neelapu SS, Gause BL, Janik JE, Muggia FM, Gockerman JP, Winter JN, Flowers CR, Nikcevich DA, Sotomayor EM, McGaughey DS, Jaffe ES, Chong EA, Reynolds CW, Berry DA, Santos CF, Popa MA, McCord AM, Kwak LW. (2011). Vaccination with patient-specific tumorderived antigen in first remission improves disease-free survival in follicular lymphoma. J Clin Oncol 29, 2787-2794. [PubMed: 21632504]

Schwartzentruber DJ, Lawson DH, Richards JM, Conry RM, Miller DM, Treisman J, Gailani F, Riley L, Conlon K, Pockaj B, Kendra KL, White RL, Gonzalez R, Kuzel TM, Curti B, Leming PD, Whitman ED, Balkissoon J, Reintgen DS, Kaufman H, Marincola FM, Merino MJ, Rosenberg SA, Choyke P, Vena D, Hwu P. (2011). gp100 peptide vaccine and interleukin-2 in patients with advanced melanoma. N Engl J Med 364, 2119-2127. [PubMed: 21631324]

Singh R, Paterson Y. (2006). Listeria monocytogenes as a vector for tumor-associated antigens for cancer immunotherapy. Expert Rev Vaccines 5, 541-552. [PubMed: 16989634]

Small EJ, Tchekmedyian NS, Rini BI, Fong L, Lowy I, Allison JP. (2007). A pilot trial of CTLA-4 blockade with human anti-CTLA-4 in patients with hormone-refractory prostate cancer. Clin Cancer Res 13, 1810-1815. [PubMed: 17363537]

Sosman JA, Carrillo C, Urba WJ, Flaherty L, Atkins MB, Clark JI, Dutcher J, Margolin KA, Mier J, Gollob J, Kirkwood JM, Panka DJ, Crosby NA, O’Boyle K, LaFleur B, Ernstoff MS. (2008). Three phase II cytokine working group trials of gp100 (210M) peptide plus high-dose interleukin-2 in patients with HLA-A2-positive advanced melanoma. J Clin Oncol 26, 22922298. [PubMed: 18467720]

Spisek R, Kukreja A, Chen LC, Matthews P, Mazumder A, Vesole D, Jagannath S, Zebroski HA, Simpson AJ, Ritter G, Durie B, Crowley J, Shaughnessy JD, Jr., Scanlan MJ, Gure AO, Barlogie B, Dhodapkar MV (2007). Frequent and specific immunity to the embryonal stem cell-associated 
antigen SOX2 in patients with monoclonal gammopathy. J Exp Med 204, 831-840. [PubMed: 17389240]

Sportes C, Babb RR, Krumlauf MC, Hakim FT, Steinberg SM, Chow CK, Brown MR, Fleisher TA, Noel P, Maric I, Stetler-Stevenson M, Engel J, Buffet R, Morre M, Amato RJ, Pecora A, Mackall CL, Gress RE. (2010). Phase I study of recombinant human interleukin-7 administration in subjects with refractory malignancy. Clin Cancer Res 16, 727-735. [PubMed: 20068111]

Stein WD, Gulley JL, Schlom J, Madan RA, Dahut W, Figg WD, Ning YM, Arlen PM, Price D, Bates SE, Fojo T. (2011). Tumor regression and growth rates determined in five intramural NCI prostate cancer trials: the growth rate constant as an indicator of therapeutic efficacy. Clin Cancer Res 17, 907-917. [PubMed: 21106727]

Tesniere A, Schlemmer F, Boige V, Kepp O, Martins I, Ghiringhelli F, Aymeric L, Michaud M, Apetoh L, Barault L, Mendiboure J, Pignon JP, Jooste V, van Endert P, Ducreux M, Zitvogel L, Piard F, Kroemer G. (2010). Immunogenic death of colon cancer cells treated with oxaliplatin. Oncogene 29, 482-491. [PubMed: 19881547]

Thiery JP. (2002). Epithelial-mesenchymal transitions in tumour progression. Nat Rev Cancer 2, $442-$ 454. [PubMed: 12189386]

Thiery JP, Sleeman JP. (2006). Complex networks orchestrate epithelial-mesenchymal transitions. Nat Rev Mol Cell Biol 7, 131-142. [PubMed: 16493418]

Thomson S, Buck E, Petti F, Griffin G, Brown E, Ramnarine N, Iwata KK, Gibson N, Haley JD. (2005). Epithelial to mesenchymal transition is a determinant of sensitivity of non-small-cell lung carcinoma cell lines and xenografts to epidermal growth factor receptor inhibition. Cancer Res 65, 9455-9462. [PubMed: 16230409]

Uchida Y, Raina D, Kharbanda S, Kufe D. (2013). Inhibition of the MUC1-C oncoprotein is synergistic with cytotoxic agents in the treatment of breast cancer cells. Cancer Biol Ther 14, 127-134. [PubMed: 23114713]

Uzendoski K, Kantor JA, Abrams SI, Schlom J, Hodge JW. (1997). Construction and characterization of a recombinant vaccinia virus expressing murine intercellular adhesion molecule-1: induction and potentiation of antitumor responses. Hum Gene Ther 8, 851-860. [PubMed: 9143911]

van den Eertwegh AJ, Versluis J, van den Berg HP, Santegoets SJ, van Moorselaar RJ, van der Sluis TM, Gall HE, Harding TC, Jooss K, Lowy I, Pinedo HM, Scheper RJ, Stam AG, von Blomberg BM, de Gruijl TD, Hege K, Sacks N, Gerritsen WR. (2012). Combined immunotherapy with granulocyte-macrophage colony-stimulating factor-transduced allogeneic prostate cancer cells and ipilimumab in patients with metastatic castration-resistant prostate cancer: a phase 1 doseescalation trial. Lancet Oncol 13, 509-517. [PubMed: 22326922]

Vanneman M, Dranoff G. (2012). Combining immunotherapy and targeted therapies in cancer treatment. Nat Rev Cancer 12, 237-251. [PubMed: 22437869]

Vega S, Morales AV, Ocana OH, Valdes F, Fabregat I, Nieto MA. (2004). Snail blocks the cell cycle and confers resistance to cell death. Genes Dev 18, 1131-1143. [PubMed: 15155580]

Vezys V, Penaloza-Macmaster P, Barber DL, Ha SJ, Konieczny B, Freeman GJ, Mittler RS, Ahmed R. (2011). 4-1BB Signaling Synergizes with Programmed Death Ligand 1 Blockade To Augment CD8 T Cell Responses during Chronic Viral Infection. J Immunol 187, 1634-1642. [PubMed: 21742975]

von Mehren M, Arlen P, Gulley J, Rogatko A, Cooper HS, Meropol NJ, Alpaugh RK, Davey M, McLaughlin S, Beard MT, Tsang KY, Schlom J, Weiner LM. (2001). The influence of granulocyte macrophage colony-stimulating factor and prior chemotherapy on the immunological response to a vaccine (ALVAC-CEA B7.1) in patients with metastatic carcinoma. Clin Cancer Res 7, 1181-1191. [PubMed: 11350882]

von Mehren M, Arlen P, Tsang KY, Rogatko A, Meropol N, Cooper HS, Davey M, McLaughlin S, Schlom J, Weiner LM. (2000). Pilot study of a dual gene recombinant avipox vaccine containing both carcinoembryonic antigen (CEA) and B7.1 transgenes in patients with recurrent CEAexpressing adenocarcinomas. Clin Cancer Res 6, 2219-2228. [PubMed: 10873071]

Walter S, Weinschenk T, Stenzl A, Zdrojowy R, Pluzanska A, Szczylik C, Staehler M, Brugger W, Dietrich PY, Mendrzyk R, Hilf N, Schoor O, Fritsche J, Mahr A, Maurer D, Vass V, Trautwein C, Lewandrowski P, Flohr C, Pohla H, Stanczak JJ, Bronte V, Mandruzzato S, Biedermann T, Pawelec G, Derhovanessian E, Yamagishi H, Miki T, Hongo F, Takaha N, Hirakawa K, Tanaka 
H, Stevanovic S, Frisch J, Mayer-Mokler A, Kirner A, Rammensee HG, Reinhardt C, SinghJasuja H. (2012). Multipeptide immune response to cancer vaccine IMA901 after single-dose cyclophosphamide associates with longer patient survival. Nat Med 18, 1254-1261. [PubMed: 22842478]

Wansley EK, Chakraborty M, Hance KW, Bernstein MB, Boehm AL, Guo Z, Quick D, Franzusoff A, Greiner JW, Schlom J, Hodge JW. (2008). Vaccination with a recombinant Saccharomyces cerevisiae expressing a tumor antigen breaks immune tolerance and elicits therapeutic antitumor responses. Clin Cancer Res 14, 4316-4325. [PubMed: 18594015]

Wheeler CJ, Black KL. (2011). Vaccines for glioblastoma and high-grade glioma. Expert Rev Vaccines 10, 875-886. [PubMed: 21692706]

Williams KM, Gress RE. (2008). Immune reconstitution and implications for immunotherapy following haematopoietic stem cell transplantation. Best Pract Res Clin Haematol 21, 579-596. [PubMed: 18790456]

Wolchok JD, Neyns B, Linette G, Negrier S, Lutzky J, Thomas L, Waterfield W, Schadendorf D, Smylie M, Guthrie T, Jr., Grob JJ, Chesney J, Chin K, Chen K, Hoos A, O’Day SJ, Lebbe C (2010). Ipilimumab monotherapy in patients with pretreated advanced melanoma: a randomised, double-blind, multicentre, phase 2, dose-ranging study. Lancet Oncol 11, 155-164. [PubMed: 20004617]

Xiang R, Luo Y, Niethammer AG, Reisfeld RA. (2008). Oral DNA vaccines target the tumor vasculature and microenvironment and suppress tumor growth and metastasis. Immunol Rev 222, 117-128. [PubMed: 18363997]

Yang AD, Fan F, Camp ER, van Buren G, Liu W, Somcio R, Gray MJ, Cheng H, Hoff PM, Ellis LM. (2006). Chronic oxaliplatin resistance induces epithelial-to-mesenchymal transition in colorectal cancer cell lines. Clin Cancer Res 12, 4147-4153. [PubMed: 16857785]

Zeytin HE, Patel AC, Rogers CJ, Canter D, Hursting SD, Schlom J, Greiner JW. (2004). Combination of a poxvirus-based vaccine with a cyclooxygenase- 2 inhibitor (celecoxib) elicits antitumor immunity and long-term survival in CEA.Tg/MIN mice. Cancer Res 64, 3668-3678. [PubMed: 15150127]

Zitvogel L, Kepp O, Senovilla L, Menger L, Chaput N, Kroemer G. (2010). Immunogenic tumor cell death for optimal anticancer therapy: the calreticulin exposure pathway. Clin Cancer Res 16, 3100-3104. [PubMed: 20421432] 


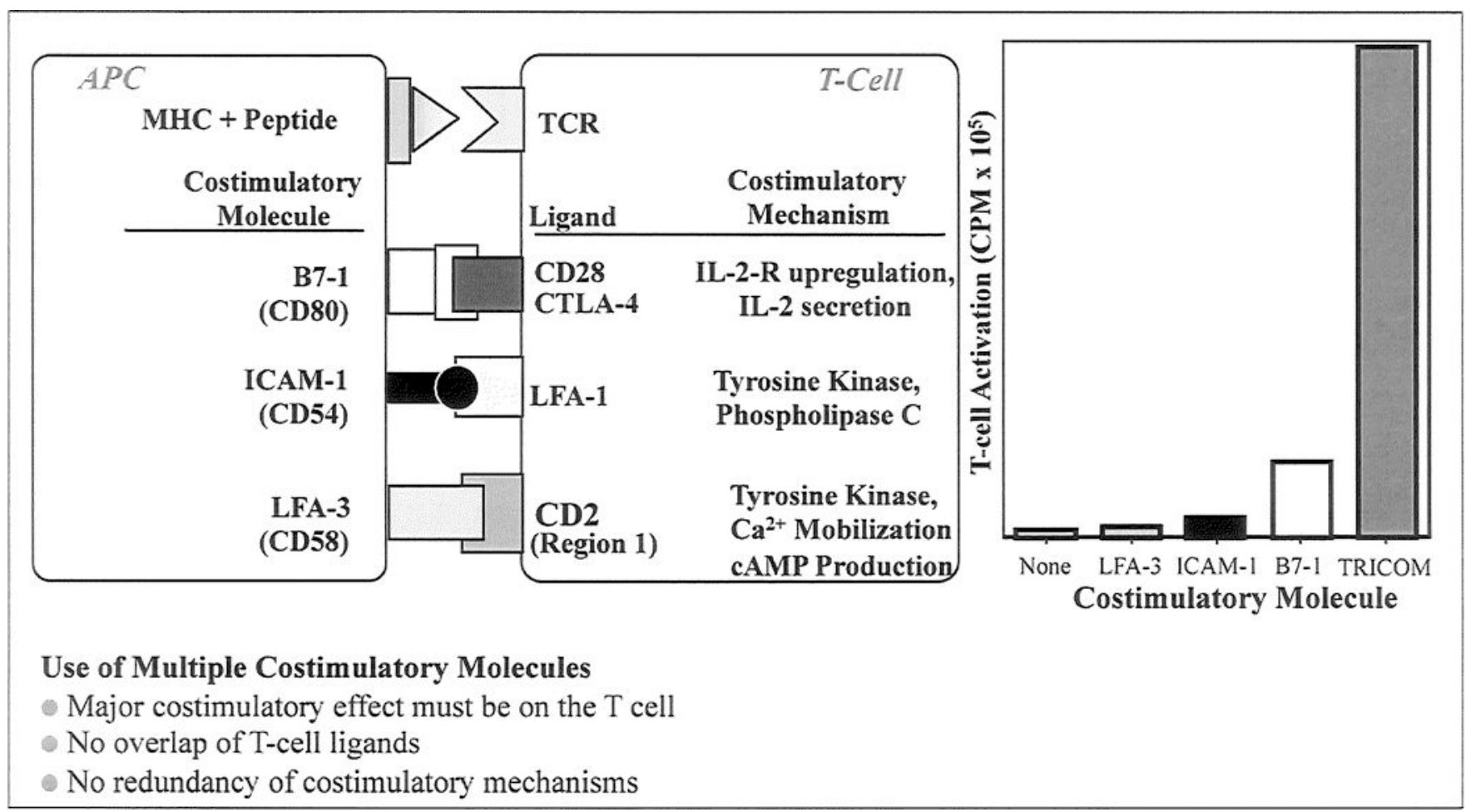

Fig. 1.

The three costimulatory molecules in TRICOM (B7.1, ICAM-1 and LFA-3) act synergistically in enhancing antigen-specific T-cell responses. Each molecule has a distinct ligand on T cells. Adapted from Schlom et al. Recombinant TRICOM-based therapeutic cancer vaccines: lessons learned (Chapter 20, pp. 309-331). In: Cancer Immunotherapy: Immune Suppression and Tumor Growth, Second Edition. G. Prendergast and E. Jaffee, eds. Elsevier Ltd. (2013). 


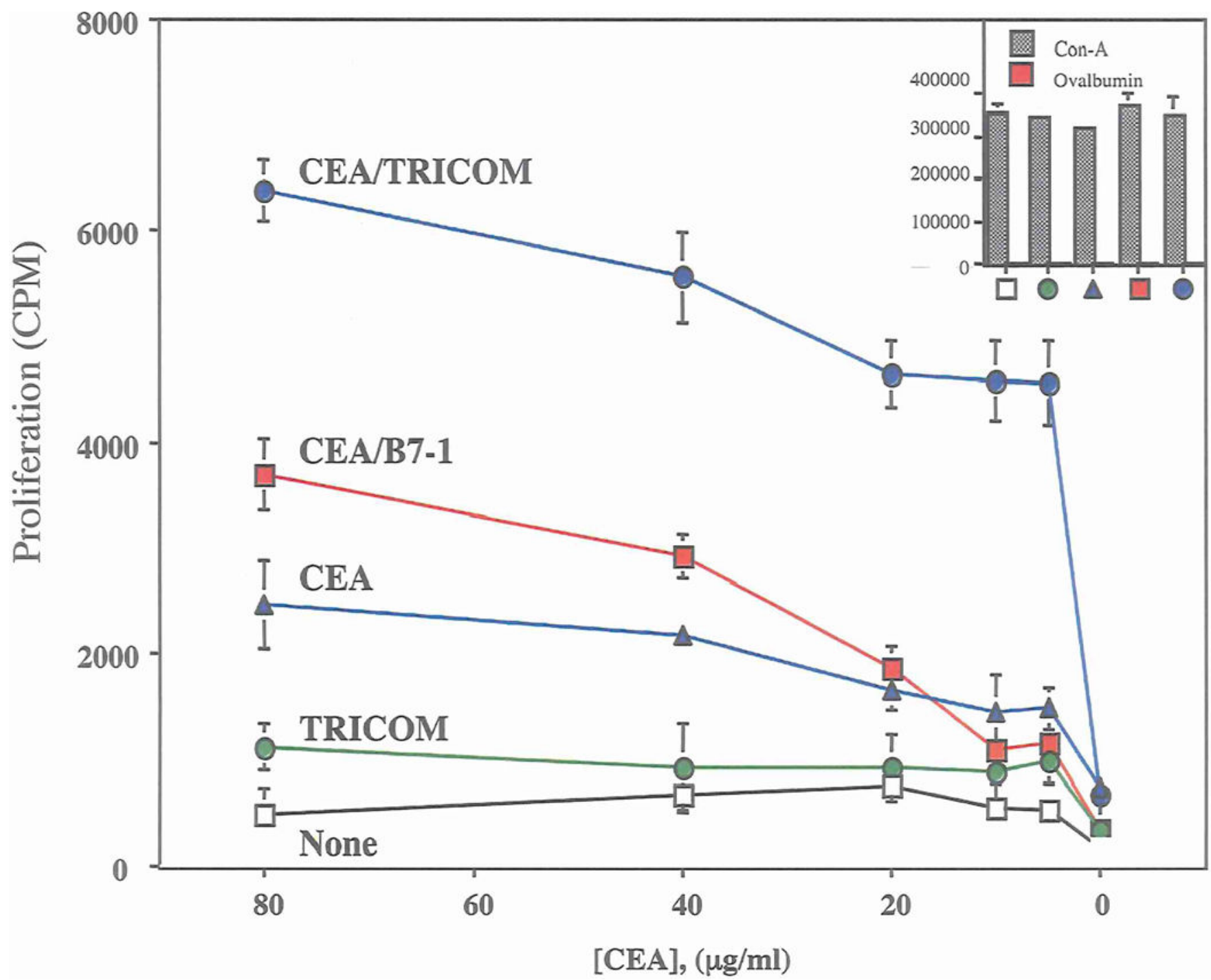

Fig. 2.

CEA-specific lymphoproliferation of $\mathrm{T}$ cells from CEA transgenic mice vaccinated with TRICOM vector (without the CEA transgene); rV-, rF-CEA; rV-, rF-CEA-B7.1; or rV-, rFCEA-TRICOM vectors. Adapted from Aarts et al. (2002). Vector-based vaccine/cytokine combination therapy to enhance induction of immune responses to a self-antigen and antitumor activity. Cancer Res. 62, 5770-5777. 

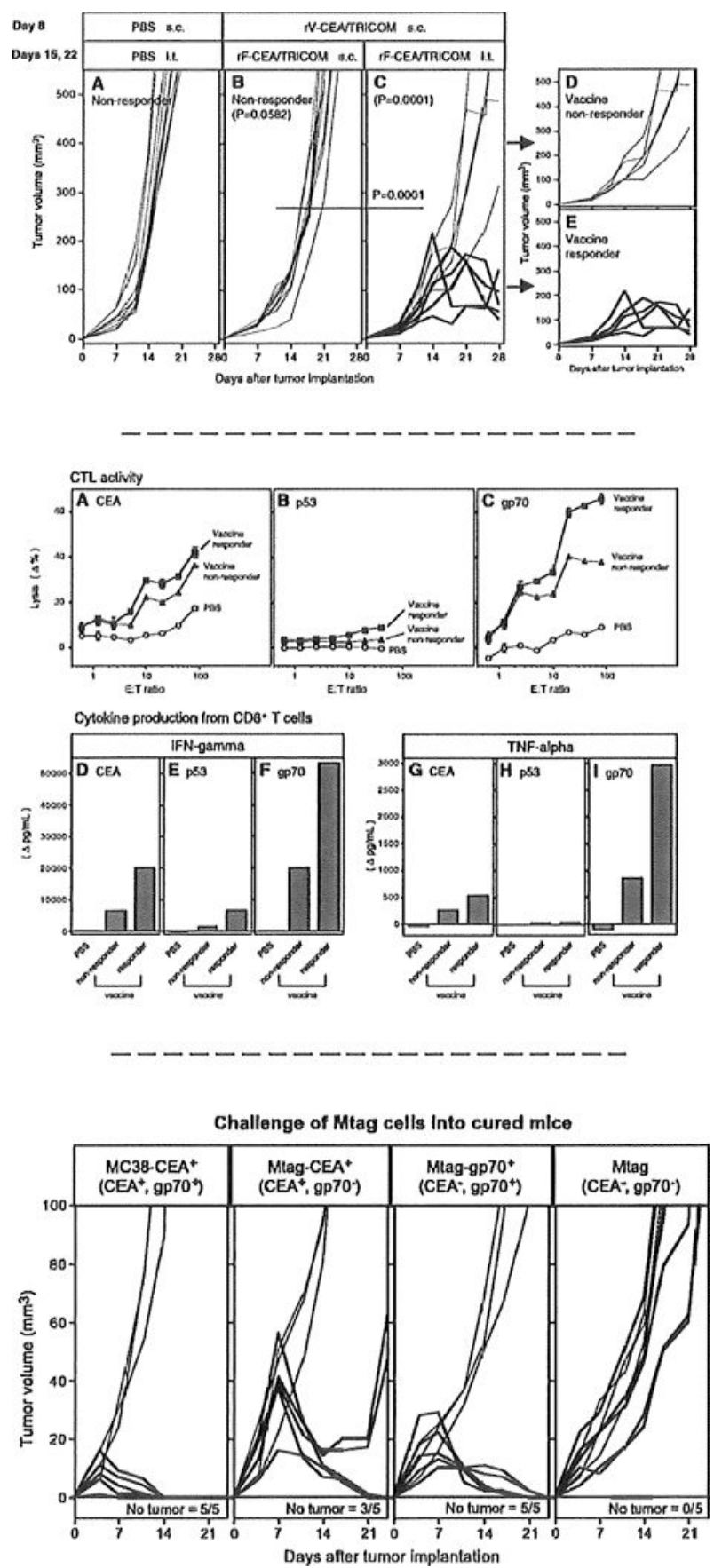

Fig. 3.

The importance of vaccine-induced antigen cascade in anti-tumor immunity. Top panel: CEA transgenic $(\mathrm{Tg})$ mice were transplanted subcutaneously (s.c.) with MC38-CEA ${ }^{+}$ tumors on day 0 . A, control mice were vaccinated with PBS vehicle s.c. on day 8 and intratumorally (i.t.) on days 15 and 22. B, mice were vaccinated s.c. with rV-CEA/TRICOM on day 8 and then boosted s.c. with rF-CEA-TRICOM on days 15 and 22. C, mice were vaccinated s.c. with rV-CEA-TRICOM on day 8 and then boosted i.t. with rF-CEATRICOM on days 15 and 22. $P$ values on day 28 compared with the PBS control group. 
Mice in $\mathbf{C}$ were separated into two groups $(\mathbf{D}$ and $\mathbf{E}$ ) based on the tumor volume and were used for subsequent immunologic analyses after tumor transplantation. Middle panel: Induction of $\mathrm{CD} 8^{+} \mathrm{T}$-cell responses to CEA, p53, and gp70 after the CEA-TRICOM vaccination. Splenic lymphocytes from CEA.Tg mice were used 29 days after tumor transplantation. A, CEA-specific CTL activity. B, p53-specific CTL activity. C, gp70specific CTL activity. Control mice treated with PBS (O), non-responders to CEA/TRICOM vaccine therapy $(\boldsymbol{\wedge})$, and responders to CEA/TRICOM vaccine therapy $(\boldsymbol{\bullet})$. D-F, antigenspecific IFN- $\gamma$ production from $\mathrm{CD} 8^{+} \mathrm{T}$ cells. G-I, antigen-specific tumor necrosis factor- $\mathrm{a}$ production from $\mathrm{CD}^{+} \mathrm{T}$ cells. Bottom panel: CEA.Tg mice were vaccinated with CEATRICOM as described. Cured mice (see panel $\mathrm{E}$ above) were challenged with tumor cells that were $\mathrm{CEA}^{+} \mathrm{gp} 70^{+}, \mathrm{CEA}^{+} \mathrm{gp} 70^{\text {neg }}, \mathrm{CEA}^{\text {neg }} \mathrm{gp} 70^{+}$, or $\mathrm{CEA}^{\text {neg }} \mathrm{gp} 70^{\text {neg }}$. The results demonstrate that some of the anti-tumor effects can be attributed to CEA in the original vaccination, but the most potent anti-tumor effects are those directed against the tumorassociated cascade antigen gp70 not in the vaccine. As a control, age/sex-matched CEA.Tg mice were implanted with the same tumors (thin lines). Adapted from Kudo-Saito et al. (2005). Induction of an antigen cascade by diversified subcutaneous/intratumoral vaccination is associated with antitumor responses. Clin Cancer Res. 11, 2416-2426. 


\section{TRICOM Vaccines}

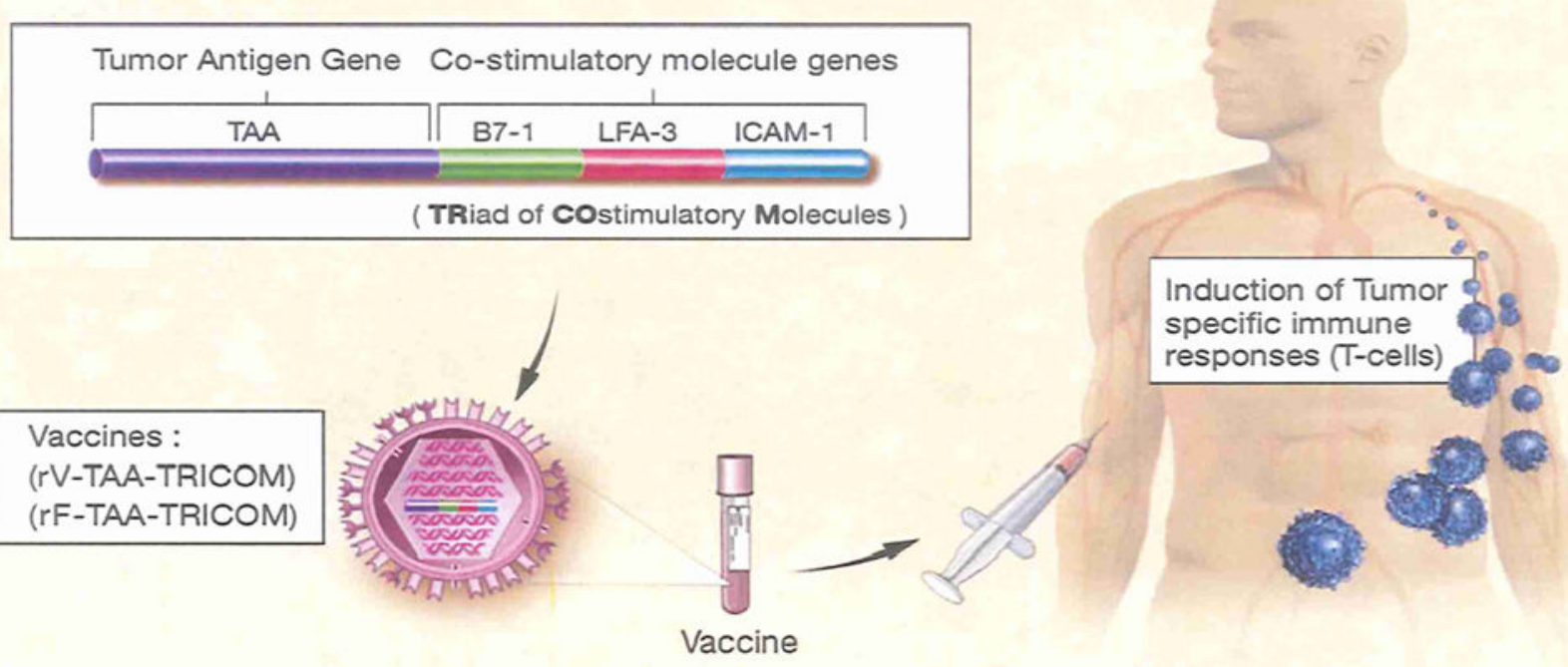

Fig. 4.

The "off-the-shelf" nature of TRICOM vaccines containing transgenes for one or more tumor-associated antigens (TAAs) and three T-cell costimulatory molecule transgenes. Prime and booster vaccinations are given subcutaneously. Adapted from Schlom et al.

Recombinant TRICOM-based therapeutic cancer vaccines: lessons learned (Chapter 20, pp. 309-331). In: Cancer Immunotherapy: Immune Suppression and Tumor Growth, Second Edition. G. Prendergast and E. Jaffee, eds. Elsevier Ltd. (2013). 
A.

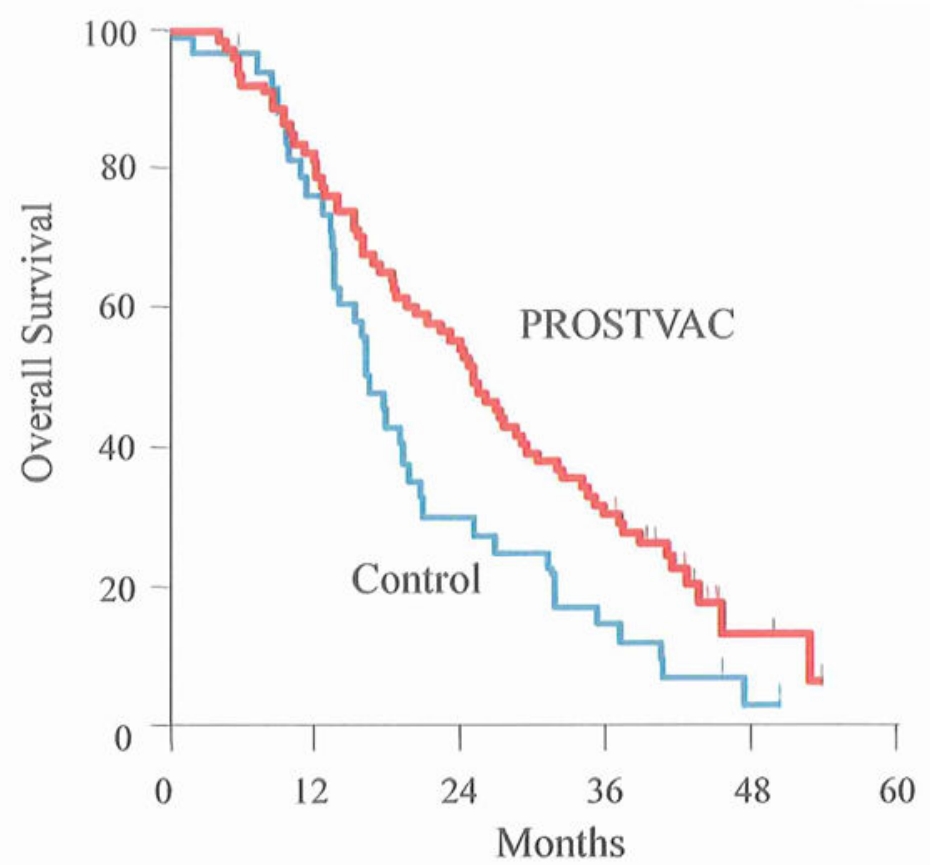

B.

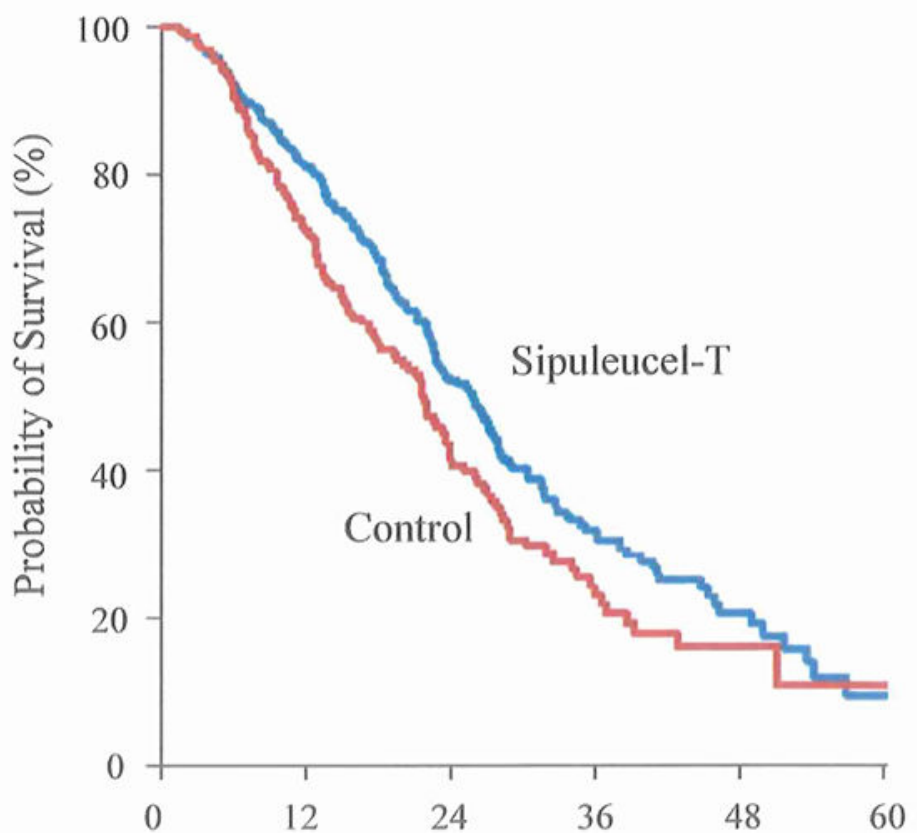

Fig. 5.

A, Overall survival (OS) of a 43-center placebo-controlled randomized Phase II study of PROSTVAC vaccination. Kaplan-Meier estimator for PROSTVAC (rV-, rF-PSA-TRICOM) arm is shown as a solid line and estimator for the control arm is a dashed line. The small vertical tic marks show the censoring times. The estimated median OS is 25.1 months for the PROSTVAC arm and 16.6 months for the control arm $(P=0.006)$. Adapted from Kantoff et al. (2010). Overall survival analysis of a Phase II randomized controlled trial of a poxviralbased PSA targeted immunotherapy in metastatic castration-resistant prostate cancer. J Clin 
Oncol. 28, 1099-1105. B, Overall survival in patients with metastatic castrate-resistant prostate cancer using the Spiluleucel-T vaccine vs. control. Sipuleucel-T improved patients' OS (hazard ratio for death $=0.78 ; P=.03$ ). Adapted from Kantoff et al. (2010). Sipuleucel-T immunotherapy for castration-resistant prostate cancer. N Engl J Med. 363, 411-422. The placebo control consisted of cultured antigen-presenting cells (APCs) from leukapheresis, without prostatic acid phosphatase-granulocyte macrophage colony-stimulating factor (PAP-GM-CSF) antigen. Per the trial protocol, the control group could receive cryopreserved APCs with antigen upon disease progression. 


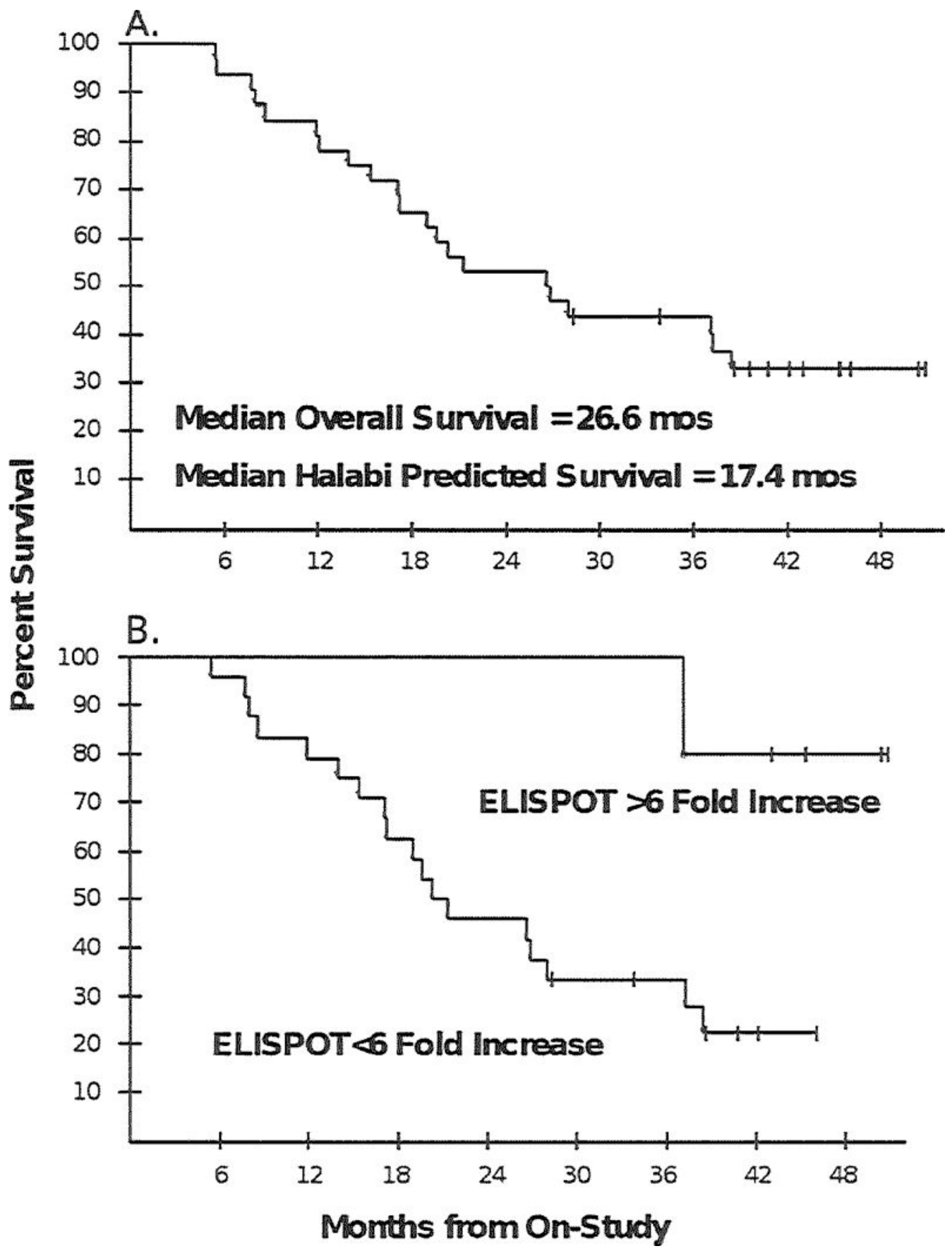

Fig. 6.

A, The Kaplan-Meier curve for the patients $(n=32)$ with metastatic prostatic cancer vaccinated with rV-, rF-PSA-TRICOM (PROSTVAC) demonstrates (panel A) a median overall survival (OS) of 26.6 months. B, There was a strong trend in the ability to mount a six-fold increase in PSA-T cells post-vaccine and an increase in OS. Adapted from Gulley et al. (2010). Immunologic and prognostic factors associated with overall survival employing a poxviral-based PSA vaccine in metastatic castrate-resistant prostate cancer. Cancer Immunol Immunother. 2010. 
A.

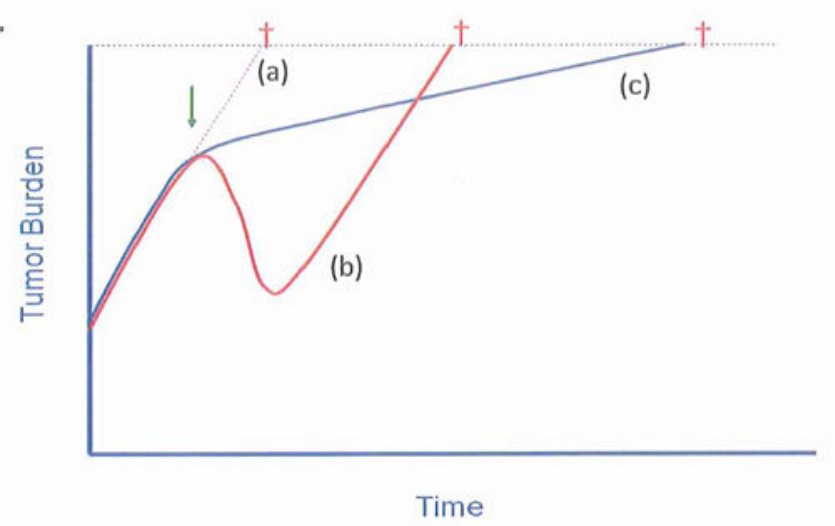

B.

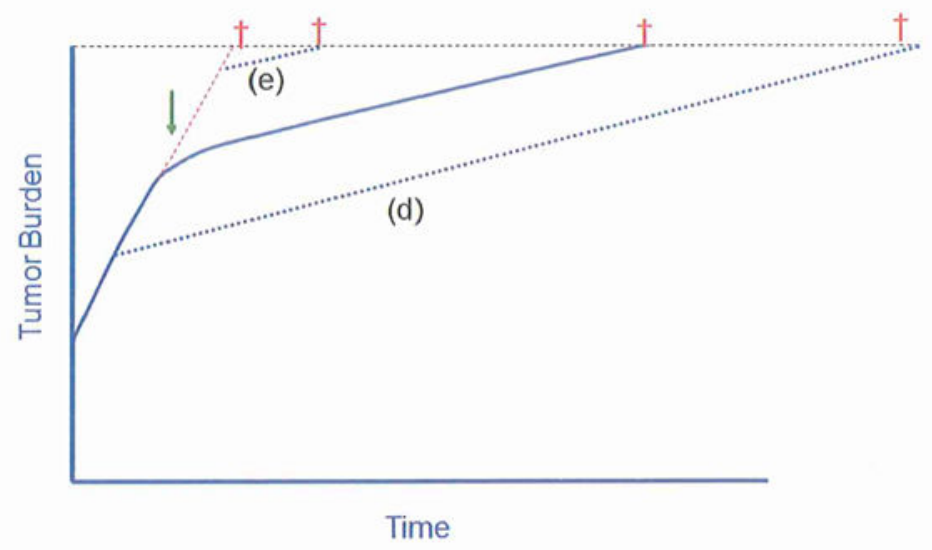

c.

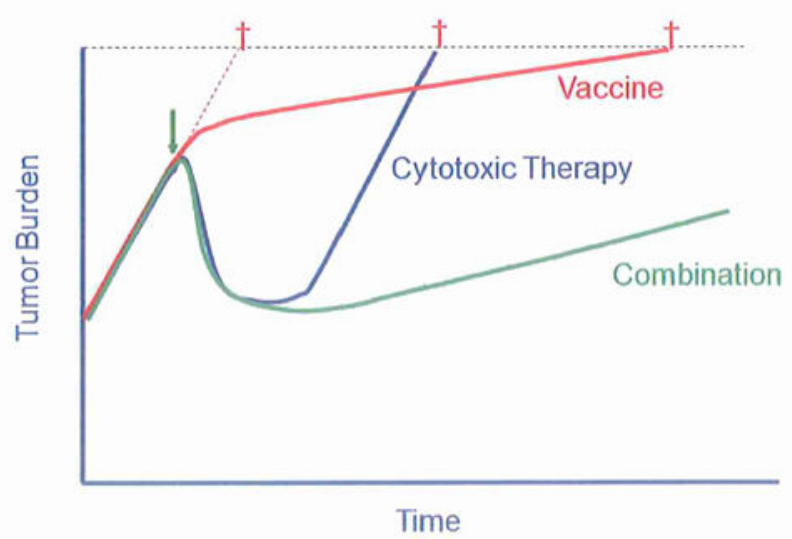

Fig. 7.

A, Tumor growth rates following chemotherapy vs. vaccine therapy. Adapted from data in Stein et al. (2011). Tumor regression and growth rates determined in five intramural NCI prostate cancer trials: the growth rate constant as an indicator of therapeutic efficacy. Clin Cancer Res. 17, 907-917; Gulley et al. (2011). The impact of tumour volume on potential efficacy of therapeutic vaccines. Curr Oncol. 18, e150-e157; Madan et al. (2010).

Therapeutic cancer vaccines in prostate cancer: the paradox of improved survival without changes in time to progression. Oncologist. 15, 969-975. A, Average tumor growth rates and 
time to death in patients with metastatic prostate cancer, from five clinical trials (four with chemotherapy and one with PROSTVAC vaccine, also known as PSA-TRICOM). Growth rate of tumor if no therapy is initiated (line a). An examination of five clinical trials (four with chemotherapy and one with PSA-TRICOM (PROSTVAC) vaccine) in patients with metastatic prostate cancer demonstrated that with the use of chemotherapy there was an initial tumor reduction, but that the growth rate of tumors at relapse (line b) was similar to the initial tumor growth rate prior to therapy; this is contrasted with the reduction in tumor growth rate following vaccine therapy (line c). Thus, for patients with little or no tumor reduction (and thus virtually no increase in time to progression), an increase in survival was observed. ( $\dagger$ ) denotes time to death. B, This phenomenon could potentially be enhanced if vaccine therapy is initiated earlier in disease progression or in patients with low tumor burden metastatic disease (line d), but would have minimal effect in patients with large tumor burden (line e). C, Additional therapies received with vaccine may take advantage of both modalities. Adapted from Schlom J. (2012). Therapeutic cancer vaccines: current status and moving forward. J Natl Cancer Inst., Oxford University Press. 104, 599-613. 
PSA (ng/mL)

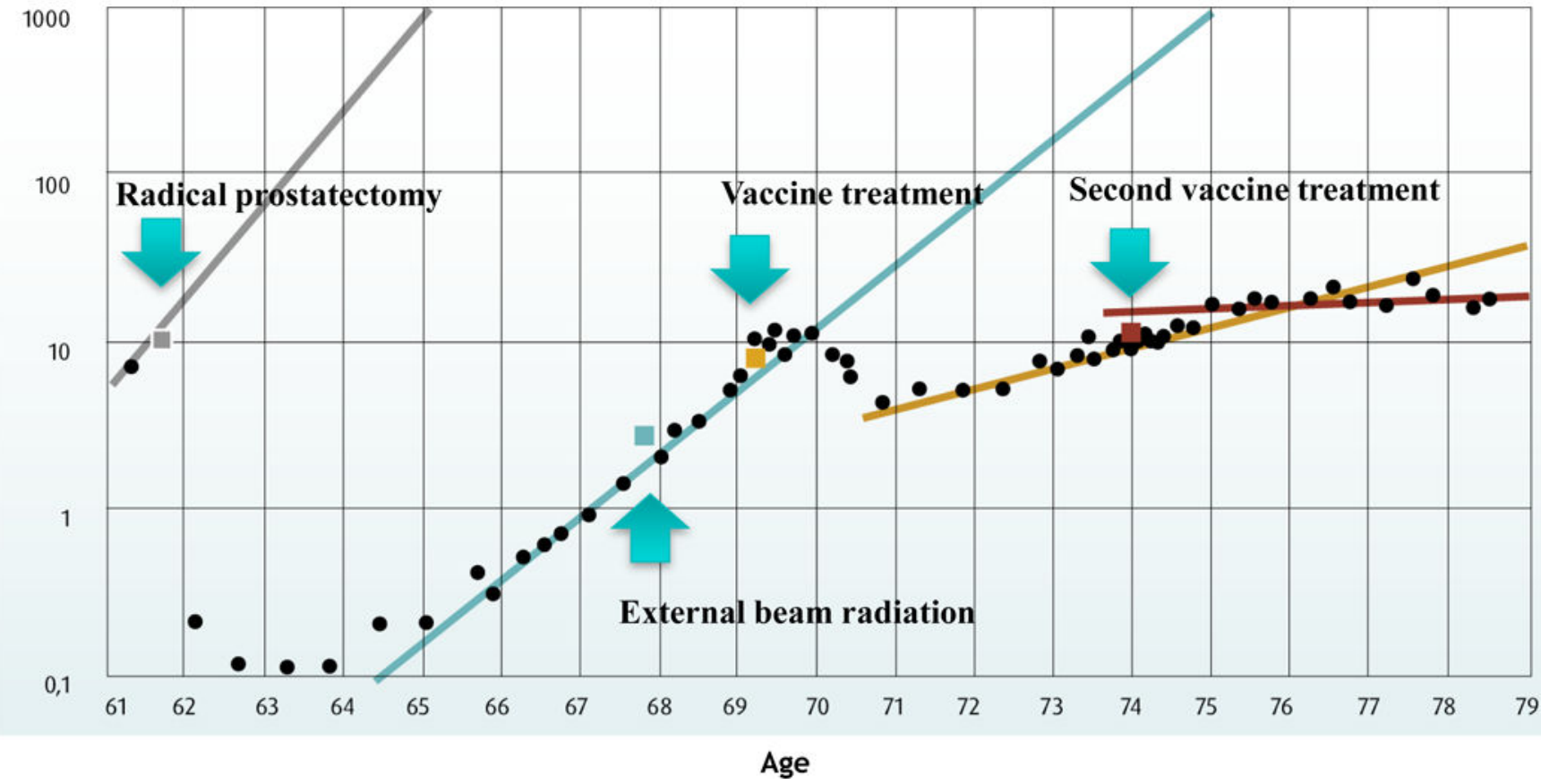

Fig. 8.

Tumor growth rate of a patient with metastatic prostate cancer receiving PSA-TRICOM vaccinations. Prostate-specific antigen (PSA) values (y-axis) are in $\mathrm{ng} / \mathrm{ml}$ and plotted on the natural $\log$ scale; PSA was measured at two different institutions as denoted by the two colors. Time (x-axis) is in years relative to prostatectomy in 1993. The solid black line is a cubic spline smooth. The dashed blue lines are the linear segments fit using segmented linear regression modeling to estimate PSA level doubling time during different periods. XRT, radiation therapy. Adapted from Rojan et al. (2013). Dramatic and prolonged PSA response after retreatment with a PSA vaccine. Clin Genitourin Cancer. 1, 362-364. 

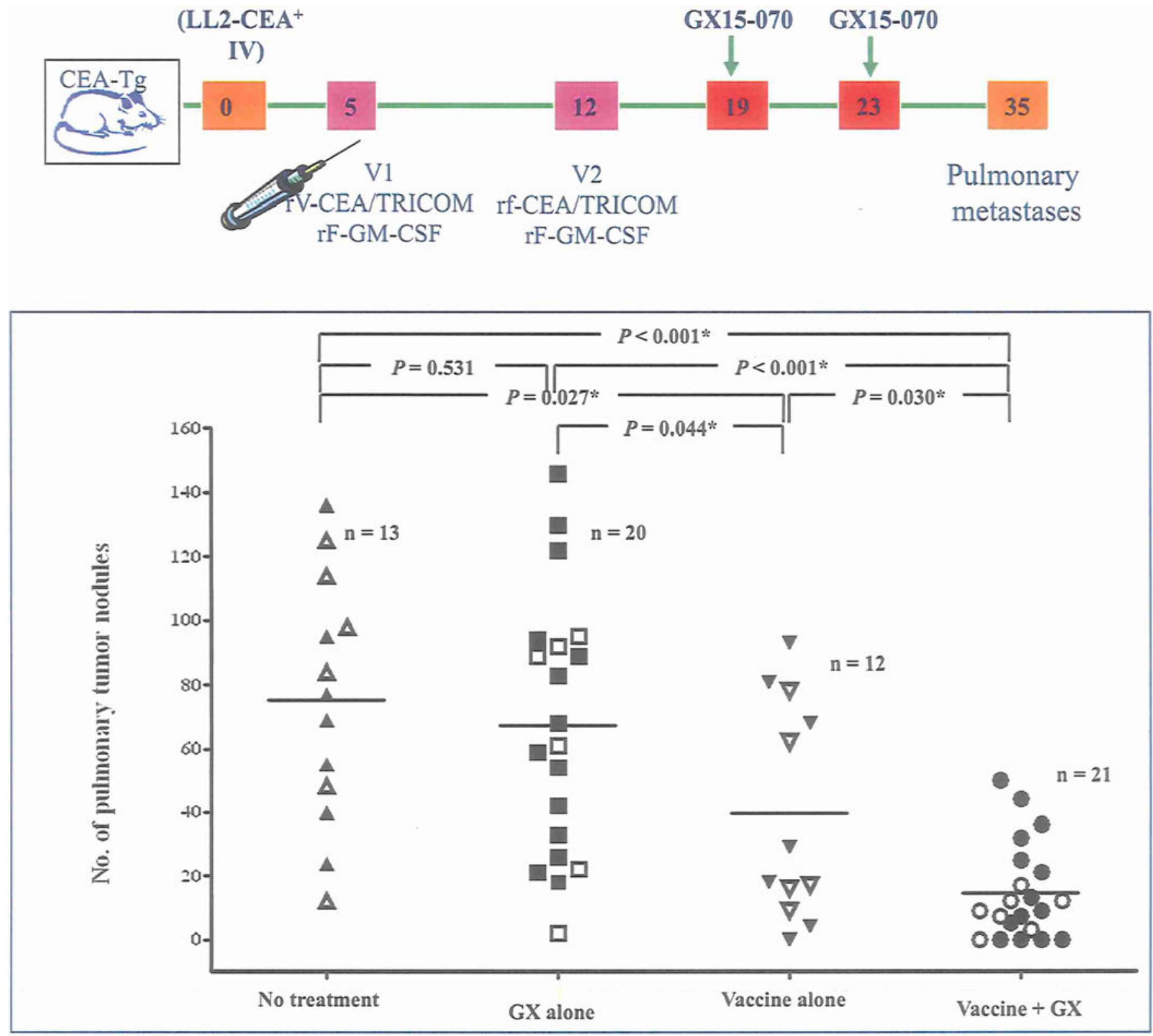

Fig. 9.

Anti-tumor effects of CEA-TRICOM vaccine in combination with a BCL-2 inhibitor (GX15-070) exploiting the differential effect of the pan BCL-2 inhibitor on Tregs vs. effector cells. Adapted from Schlom et al. Recombinant TRICOM-based therapeutic cancer vaccines: lessons learned (Chapter 20, pp. 309-331). In: Cancer Immunotherapy: Immune Suppression and Tumor Growth, Second Edition. G. Prendergast and E. Jaffee, eds. Elsevier Ltd. (2013). 
A

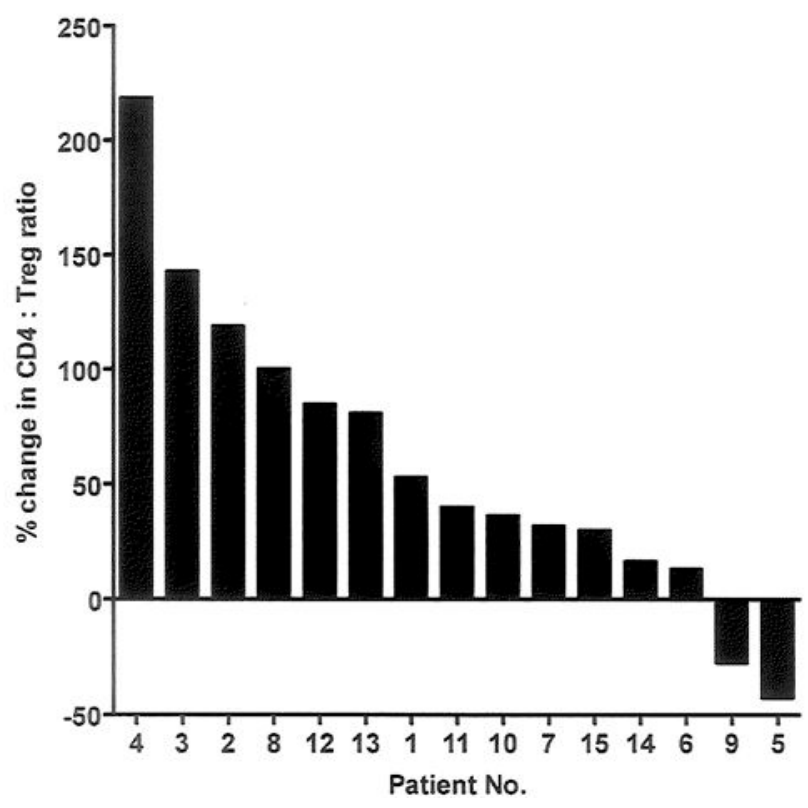

B

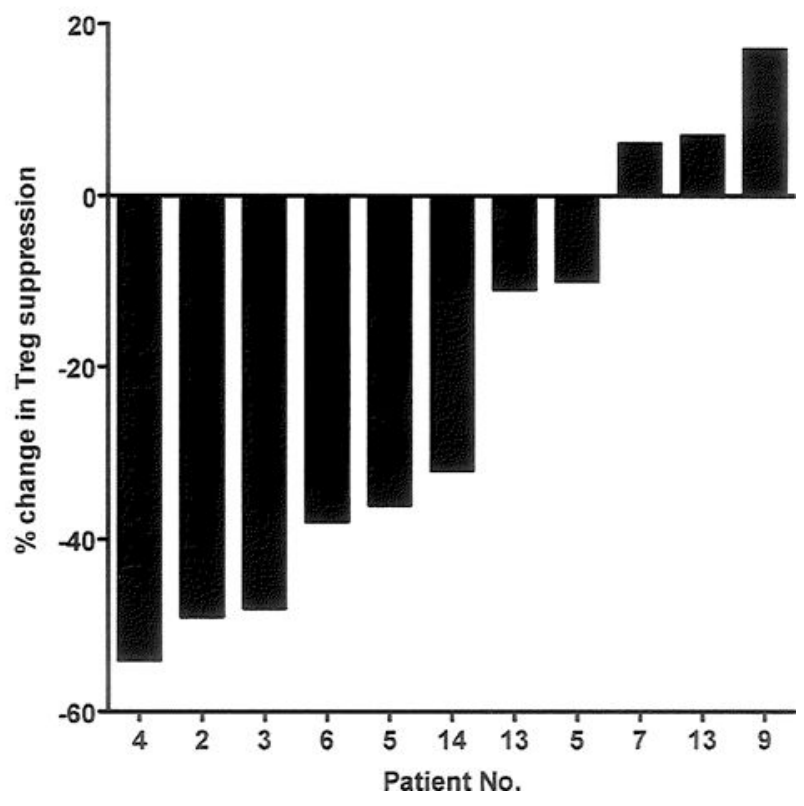

Fig. 10.

Changes in Teff:Tregs ratios and suppressive activity of Tregs during therapy with docetaxel in patients with hormone refractory prostate cancer. A, Waterfall plot of the change in the ratio of Teff:Tregs during therapy with docetaxel in patients with hormone refractory prostate cancer. Peripheral blood samples were collected prior to therapy and before starting cycle II. B, Waterfall plot of the change in suppressive activity of Tregs during therapy with docetaxel. Adapted from Roselli et al. (2013). The effect of nonimmune therapeutic interventions on regulatory T-cell number and function. OncoImmunology. Epub: 11.1.13. 
A
B

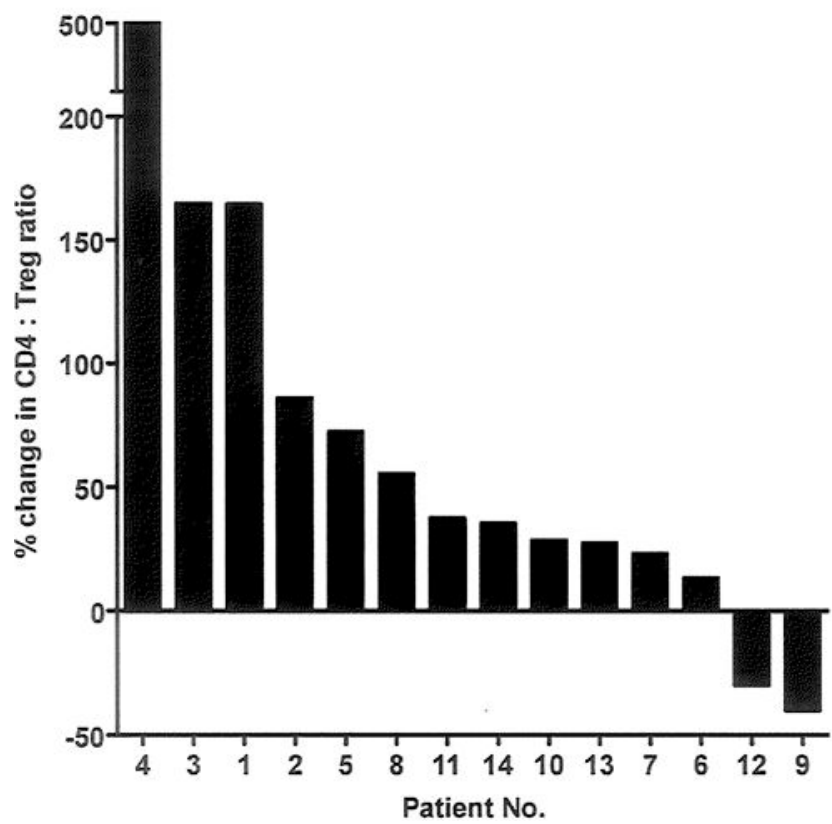

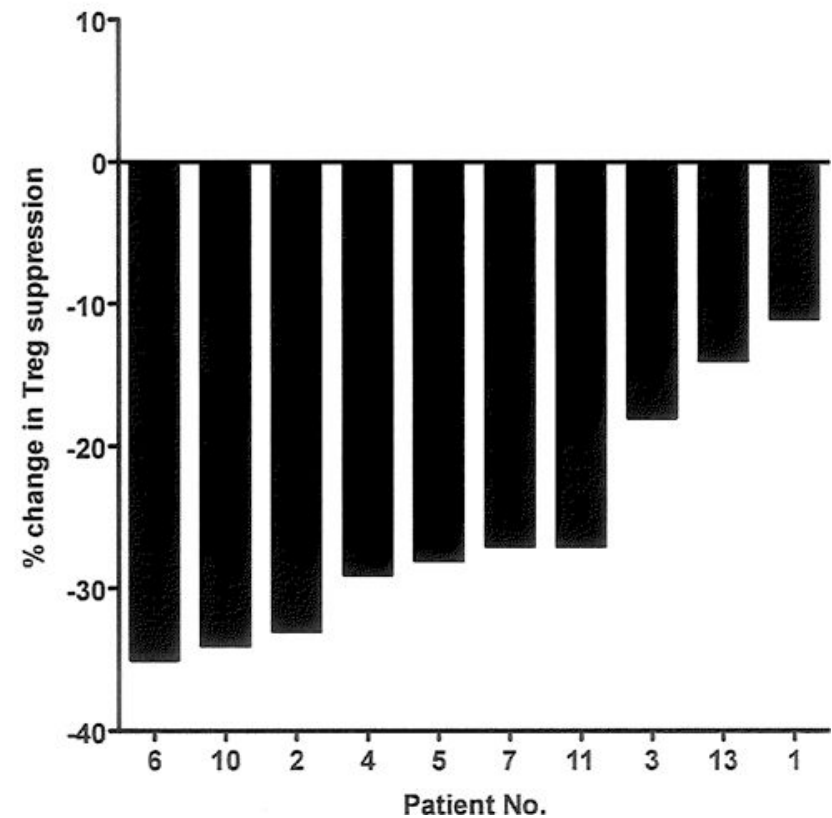

Fig. 11.

Changes in Teff:Tregs ratios and suppressive activity of Tregs in non-small cell lung cancer (NSCLC) patients before and during therapy with cisplatin plus vinorelbine. A, Waterfall plot of the change in the ratio of Teff:Tregs in NSCLC patients before and during therapy with cisplatin plus vinorelbine. Patients with NSCLC were treated in the adjuvant setting, post-surgery. PBMCs were collected from peripheral blood at baseline and post-cycle III. B, Waterfall plot of the change in suppressive activity of Tregs from NSCLC patients before and during therapy with cisplatin plus vinorelbine. Adapted from Roselli et al. (2013). The effect of nonimmune therapeutic interventions on regulatory T-cell number and function. OncoImmunology. Epub: 11.1.13 


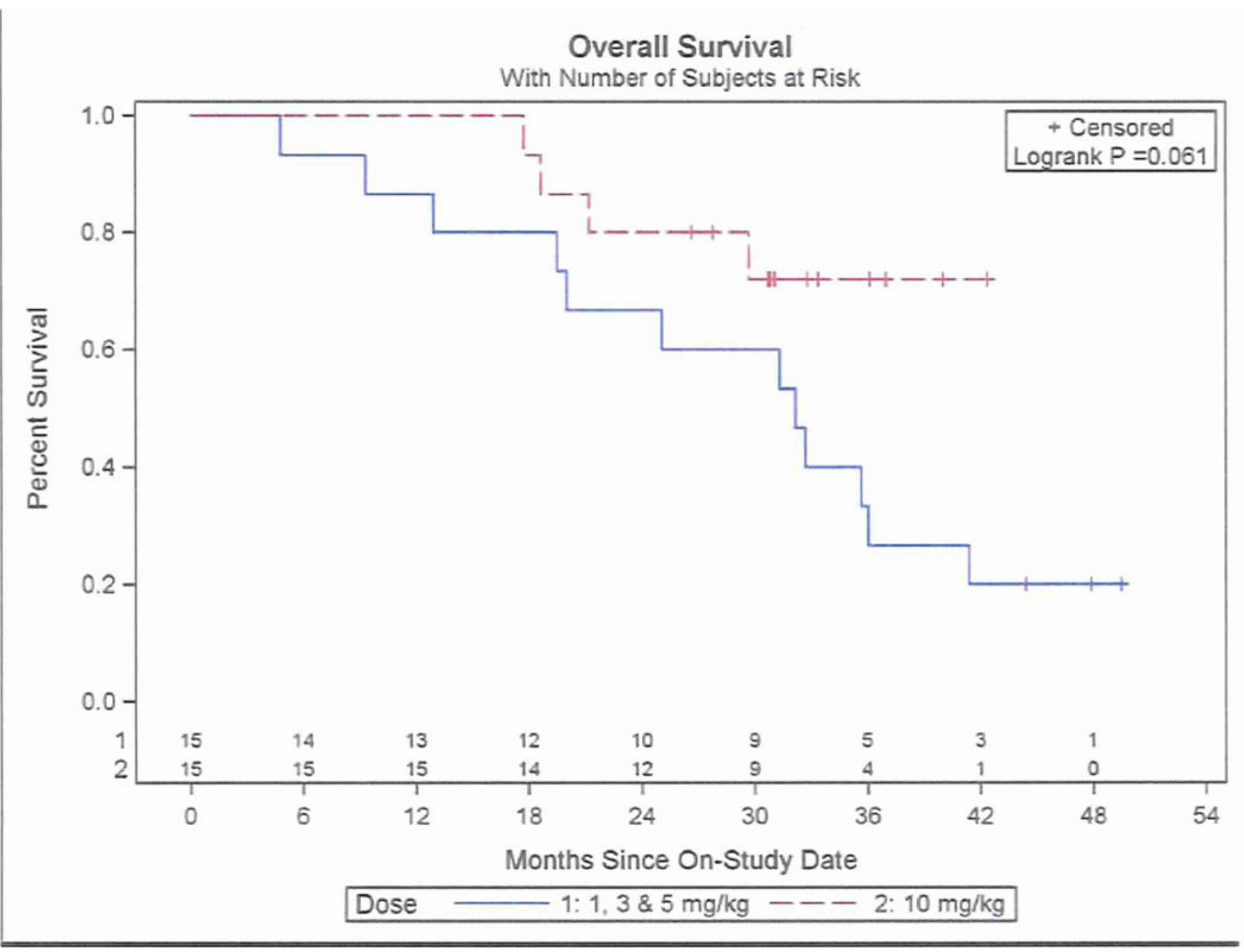

Fig. 12.

There was a trend toward improved overall survival in chemotherapy naïve metastatic prostate cancer patients treated with PROSTVAC vaccine and the $10-\mathrm{mg} / \mathrm{kg}$ dose of ipilimumab relative to lower dose levels of ipilimumab. Adapted from Madan et al. (2012). Ipilimumab and a poxviral vaccine targeting prostate-specifi c antigen in metastatic castration-resistant prostate cancer: a phase 1 dose-escalation trial. Lancet Oncol. 13, 501508 . 


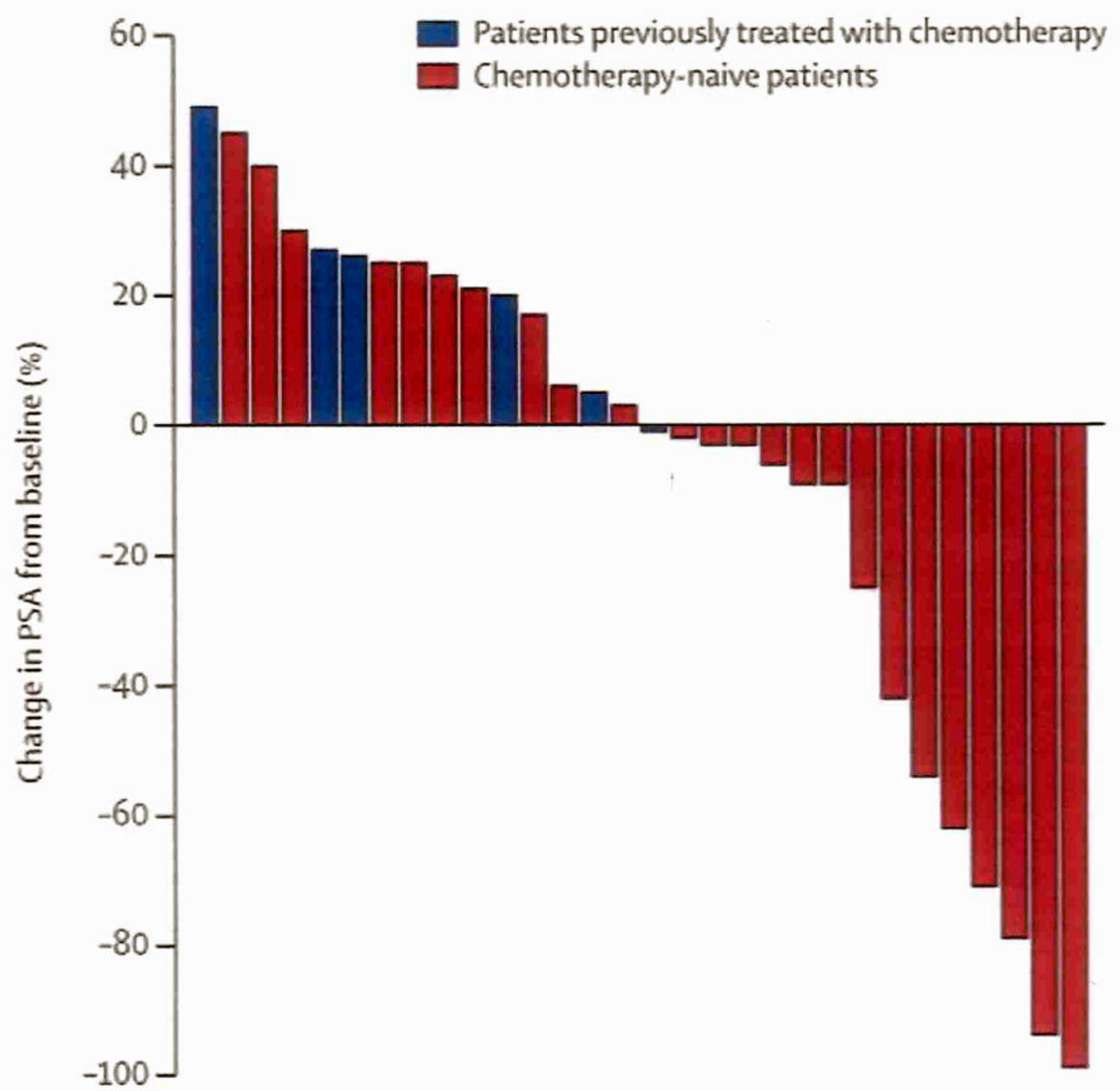

Fig. 13.

Best prostate-specific antigen (PSA) responses after treatment with PROSTVAC vaccine plus ipilimumab. $25 \%$ of patients had PSA declines $>50 \%$ post-treatment. Adapted from Madan et al. (2012). Ipilimumab and a poxviral vaccine targeting prostate-specifi c antigen in metastatic castration-resistant prostate cancer: a phase 1 dose-escalation trial. Lancet Oncol. 13, 501-508. 
A

PANC-1

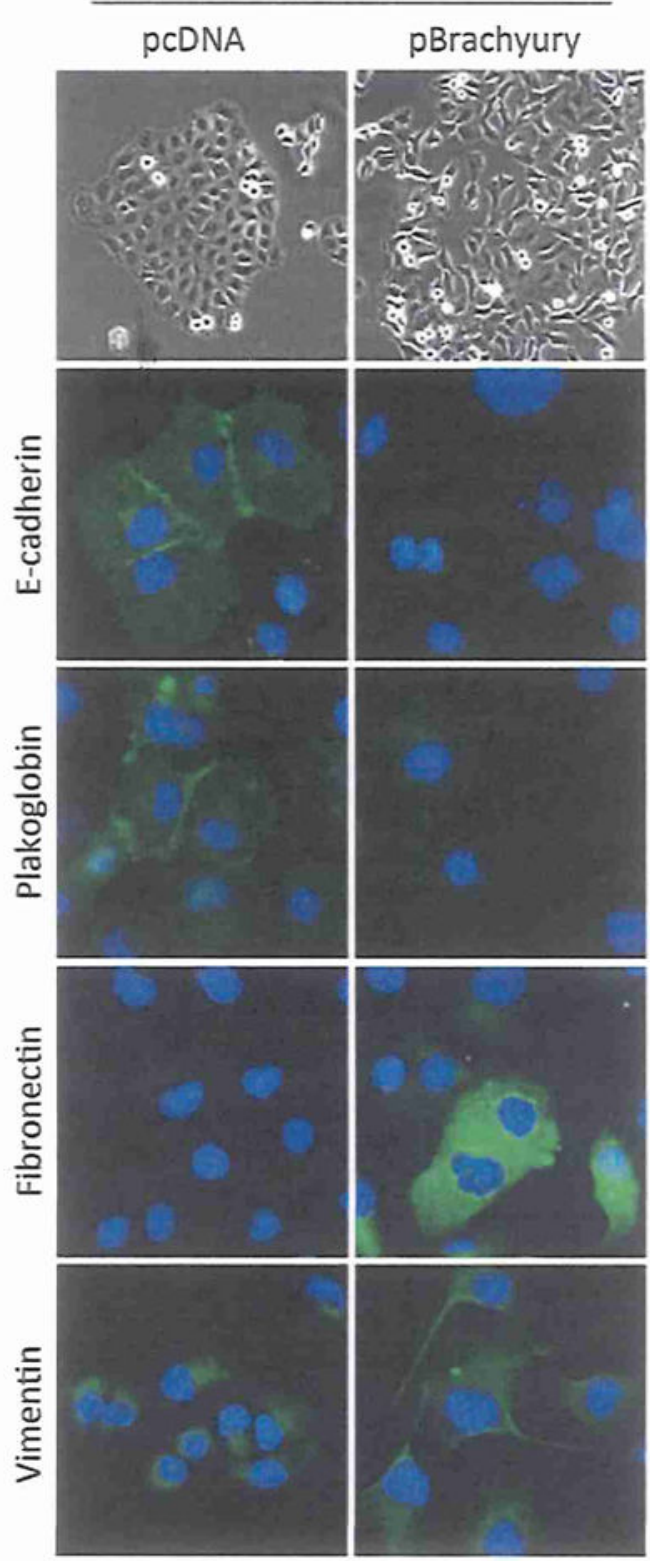

B

Fig. 14.

Brachyury induces epithelial to mesenchymal transition (EMT) in human carcinoma cells. A, Pancreatic carcinoma PANC-1 cells were stably transfected with a control pcDNA or a vector encoding for full length Brachyury (pBrachyury). Top panels: bright field images of cells grown on plastic surface. Bottom panels: immunofluorescence analysis of EMT markers in cells grown on cover glasses. The green signal represents the staining of the corresponding protein, and the blue signal represents the DAPI-stained nuclei. B, In vitro cell migration and ECM invasion assays. Adapted from Fernando et al. (2010). The T-box transcription factor Brachyury promotes epithelial-to-mesenchymal transition in human tumor cells. J Clin Invest. 120, 533-544. 

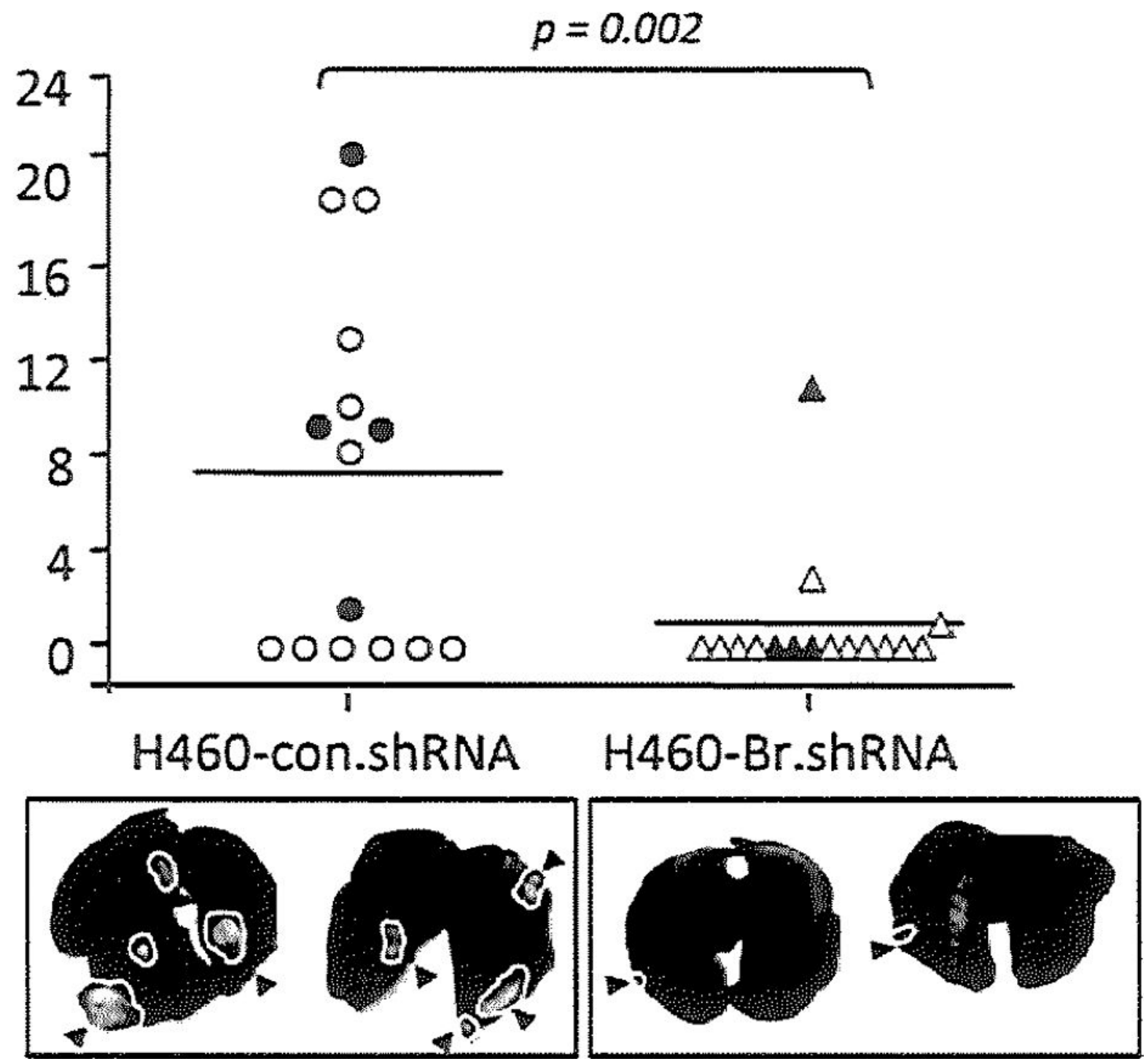

Fig. 15. Brachyury controls tumor dissemination and metastasis.

Athymic mice were inoculated with human H460 lung carcinoma cells transfected as indicated via tail vein. Forty-five days after tumor implantation, animals were euthanized and lungs were evaluated for tumor nodules. Circles denote con.shRNA and triangles denote Br.shRNA. Two representative lungs from each group are shown for comparison. White outlines and black arrowheads point to tumor masses. Adapted from Fernando et al. (2010). The T-box transcription factor Brachyury promotes epithelial-to-mesenchymal transition in human tumor cells. J Clin Invest. 120, 533-544. 
A

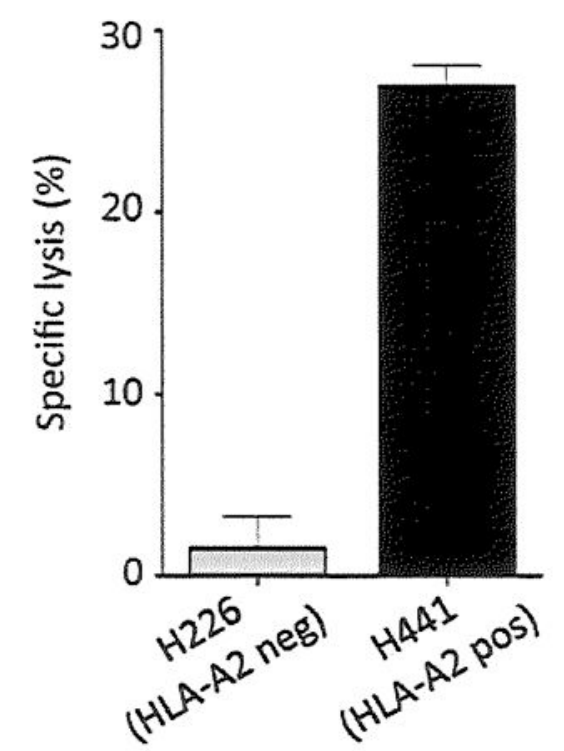

B

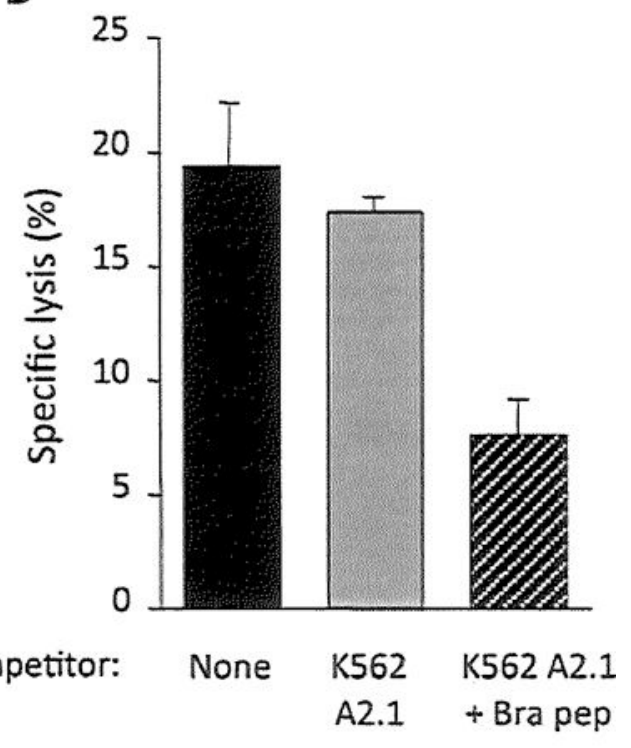

c

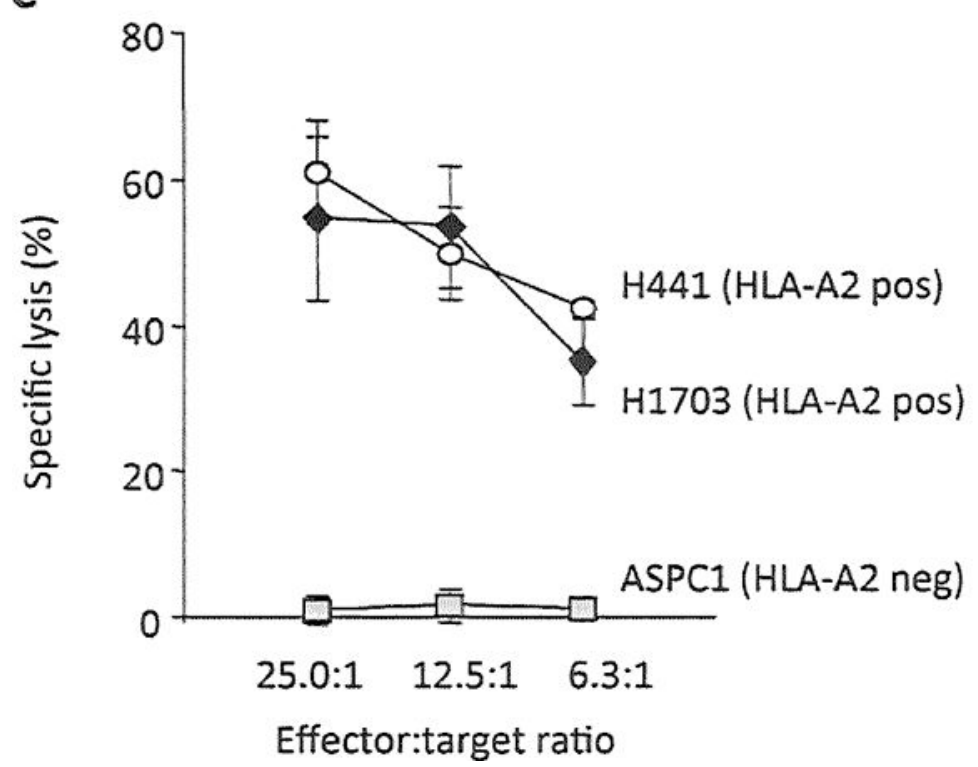

Fig. 16.

Brachyury as a vaccine target. A, MHC-restricted CTL-mediated lysis of H226 (HLA-A2 negative) and H441 (HLA-A2 positive) lung carcinoma cells with a Brachyury-specific Tcell line. B, Lysis of H441 tumor cells with a Brachyury-specific T-cell line derived from a prostate cancer patient in the presence of cold, competitor K562 A2.1 cells unpulsed or pulsed with the specific Brachyury peptide (Bra pep). C, Lysis of H441 and H1703 lung carcinoma and control ASPC1 cells by tetramer-isolated, $\mathrm{CD} 8^{+}$Brachyury-specific T-cell line derived from a different prostate cancer patient. Adapted from Roselli et al. (2012). 
Brachyury, a driver of the epithelial-mesenchymal transition, is overexpressed in human lung tumors: an opportunity for novel interventions against lung cancer. Clin Cancer Res. 18, 3868-3879. 
Table 1

Spectrum of Current and Potential Therapeutic Cancer Vaccine Targets

\begin{tabular}{|c|c|c|}
\hline Target type & Examples & Reference \\
\hline Oncoprotein & $\begin{array}{l}\text { point mutated: ras, B-raf, frame shift } \\
\text { mutations, undefined unique tumor } \\
\text { mutations; HER2/neu, MUC-1 C- } \\
\text { terminus, p53 }\end{array}$ & $\begin{array}{l}\text { Disis et al., 2009; Salazar et al., 2009; Brichard et al., 2008; Kufe et al., 2009; } \\
\text { Raina et al.,2011. }\end{array}$ \\
\hline Stem cell/EMT & $\begin{array}{l}\text { Brachyury, SOX-2, OCT- } 4 \text {, TERT, } \\
\text { CD } 44^{\text {high }} / \text { CD } 24^{\text {lo }}, \text { CD } 133^{+}\end{array}$ & $\begin{array}{l}\text { Polyak et al., 2009; Dhodapkar et al., 2010; Dhodapkar et al., 2011; Hua et al., } \\
\text { 2011; Mine et al., 2009; Spisek et al., 2007; Fernando et al., 2010; Palena et al., } \\
\text { 2007; Fernando et al., 2011 }\end{array}$ \\
\hline Oncofetal antigen & CEA, MUC-1, MUC1-C & $\begin{array}{l}\text { Butts et al., 2005; Pejawar-Gaddy et al., 2010; Finn et al., 2011; (Jochems, C, } \\
\text { Tucker, Vergati, B., J.L., J and K-Y et al., (in press)) }\end{array}$ \\
\hline Cancer-testes & $\begin{array}{l}\text { MAGE-A3, BAGE, SEREX-defined, } \\
\text { NY-ESO }\end{array}$ & $\begin{array}{l}\text { Karbach et al., 2011; Gnjatic et al., 2010; Gnjatic et al., 2009b; Hofmann et al., } \\
2008\end{array}$ \\
\hline Tissue lineage & $\begin{array}{l}\text { PAP, PSA, gp100, tyrosinase, glioma } \\
\text { antigen }\end{array}$ & $\begin{array}{l}\text { Schwartzentruber et al., 2011; Sosman et al., 2008; Kantoff et al., 2010b; Gulley } \\
\text { et al., 2010b; Kaufman et al., 2004; Kantoff et al., 2010a; Okada et al., 2011; } \\
\text { Wheeler et al., } 2011\end{array}$ \\
\hline Viral & $\mathrm{HPV}, \mathrm{HCV}$ & Kemp et al., 2008; Kemp et al., 2011 \\
\hline B-cell lymphoma & Anti-id & $\begin{array}{l}\text { Schuster et al., 2011; Bendandi et al., 2009; Inoges et al., 2006; Freedman et al., } \\
2009\end{array}$ \\
\hline Antiangiogenic & VEGF-R & Kaplan et al., 2006; Xiang et al., 2008; Frazer et al., 2007 \\
\hline Glycopeptides & STn-KLH & Gilewski et al., 2007; Ragupathi et al., 2009 \\
\hline
\end{tabular}

*BAGE, B melanoma antigen; CEA, carcinoembryonic antigen; EMT, epithelial-mesenchymal transition; gp100, glycoprotein 100; HCV, hepatitis C virus; HPV, human papillomavirus; MAGE-A3, melanoma-associated antigen-A3; MUC-1, mucin 1; NY-ESO, New York esophageal carcinoma antigen 1; OCT-4, octamer-binding transcription factor 4; PAP, prostatic acid phosphatase; PSA, prostate-specific antigen; SOX-2, (sex determining region Y)-box-2; STn-KLH, sialyl-Tn-keyhole limpet hemocyanin; TERT, telomerase reverse transcriptase; VEGF-R, vascular endothelial growth factor receptor. 
Table 2

Spectrum of Current Vaccine Platforms in Phase II/III Clinical Studies

\begin{tabular}{|c|c|c|c|}
\hline Vaccine platform & Example & Cancer type & Reference \\
\hline \multicolumn{4}{|l|}{ Dendritic Cells/APCs } \\
\hline APC-protein & Sipuleucel-T (PAP-GM-CSF) & Prostate & $\begin{array}{l}\text { Kantoff et al., 2010a; } \\
\text { Higano et al., } 2009\end{array}$ \\
\hline Dendritic cell-peptide & Glioma peptides & Glioma, melanoma & $\begin{array}{l}\text { Banchereau et al., } \\
\text { 1998; Okada et al., } \\
\text { 2011; Banchereau et } \\
\text { al., } 2001\end{array}$ \\
\hline Dendritic cells-vector infected & rV, rF-CEA-MUC1-TRICOM (Panvac-DC) & Colorectal & $\begin{array}{l}\text { Lyerly et al., 2011; } \\
\text { Morse et al., 2011; } \\
\text { Morse et al., } 2013\end{array}$ \\
\hline \multicolumn{4}{|l|}{ Tumor Cells } \\
\hline Autologous & adeno-CD40L, colon (BCG) & CLL, colon, melanoma & $\begin{array}{l}\text { Okur et al., 2011; } \\
\text { Hoover et al., 1993; } \\
\text { Luiten et al., } 2005\end{array}$ \\
\hline $\begin{array}{l}\text { Dendritic cell/autologous tumor } \\
\text { cell fusions }\end{array}$ & Myeloma/DC fusion & Myeloma & Avigan et al., 2004 \\
\hline Allogeneic & GVAX (+GM-CSF) & Pancreatic & $\begin{array}{l}\text { Laheru et al., 2008; } \\
\text { Lutz et al., 2011; } \\
\text { Emens et al., } 2009\end{array}$ \\
\hline
\end{tabular}

Recombinant Vectors

Poxvirus

Saccharomyces cerevisiae (yeast)

Listeria

Alpha- and adenoviruses
rV, rF-PSA-TRICOM (Prostvac)

yeast-ras

Listeria-mesothelin

adeno-CEA, alpha-CEA
Prostate

Pancreatic

Pancreatic

Carcinoma
Moss et al., 1996; Hodge et al., 2009; Marshall et al., 2000;

Hodge et al., 2003;

von Mehren et al., 2001; von Mehren et al., 2000; Madan et al., 2010b; Kantoff et al., 2010b; Gulley et al., 2011; Marshall et al., 2005; Kaufman et al., 2004; Arlen et al., 2006; Sanda et al., 1999

Remondo et al., 2009; Wansley et al., 2008

Singh et al., 2006

MacDonald et al., 2000

\section{Peptides/Proteins}

Peptide gp100 (modified), MUC-1 (Stimuvax), HER2/neu
Disis et al., 2009;

Butts et al., 2005;

Pejawar-Gaddy et al., 2010; Finn et al.,

2011;

Melanoma, lung
Schwartzentruber et al., 2011; Sosman et al., 2008; Salazar et al., 2009; Brichard et al.,2008; Disis et al., 2011 


\begin{tabular}{llll}
\hline \multicolumn{1}{c}{ Vaccine platform } & Example & Cancer type & Reference \\
\hline Protein & MAGE-A3, NY-ESO & Melanoma & Karbach et al., 2011 \\
& & & Schuster et al., 2011; \\
Antibody & Anti-idiotype & Lendandi et al., 2009; \\
& & & Inoges et al., 2006; \\
& \multirow{2}{*}{ sTn-KLH } & & Freedman et al., 2009 \\
Glycoproteins & Melanoma & Gilewski et al., 2007; \\
& Ragupathi et al., 2009 \\
\hline
\end{tabular}

*APC, antigen-presenting cell; BCG, Bacillus Calmette-Guerin adjuvant; CD40L, CD40 ligand; CEA, carcinoembryonic antigen; CLL, chronic lymphocytic leukemia; DC, dendritic cell; gp100, glycoprotein 100; GM-CSF, granulocyte macrophage colony-stimulating factor; MAGE-A3, melanoma-associated antigen 3; MUC-1, mucin 1; NY-ESO, New York esophageal carcinoma antigen 1; PAP, prostatic acid phosphatase; PSA, prostate-specific antigen; rF, recombinant fowlpox; rV, recombinant vaccinia; STn-KLH, sialyl-Tn-keyhole limpet hemocyanin. 
Table 3

Properties of Recombinant Poxviral Vaccine Vectors

- Vectors

Vaccinia (rV-) elicits a strong immune response

- host induced immunity limits its continuous use

- MVA (replication defective)

Avipox (fowlpox rF-, ALVAC)

- derived from avian species

- safe; does not replicate

- can be used repeatedly with little if any host neutralizing immunity

- Can insert multiple transgenes

- Do not integrate into host DNA

- Efficiently infect antigen presenting cells including dendritic cells 
Table 4

TRICOM: TRIad of COstimulatory Molecules

\begin{aligned} & \hline Costimulatory Molecule Ligand on T cell \\ & B7.1 (CD80) CD28/CTLA-4 \\ & ICAM-1 (CD54) LFA-1 \\ & LFA-3 (CD58) CD2 \\ & TRICOM $=$ B7-1/ICAM-1/LFA-3 \\ & CEA/TRICOM $=$ CEA/B7-1/ICAM-1/LFA-3 \\ & CEA/MUC-1/TRICOM $=$ CEA/MUC-1/B7-1/ICAM-1/LFA-3 (PANVAC) \\ & PSA/TRICOM $=$ PSA/B7-1/ICAM (PROSTVAC) \end{aligned}

All vaccines contain: $r V$ - as a prime vaccine

avipox (fowlpox, rF-) as multiple booster vaccines

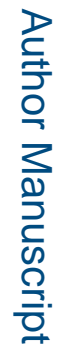

CEA, MUC-1, and PSA transgenes all contain enhancer agonist 


\section{Table 5}

Vaccines in Combination with Other Therapeutic Modalities

\begin{tabular}{ll}
\hline Modality & Mechanism of action to enhance vaccine efficacy \\
\hline Hormonal therapy & Thymic regeneration and induction of naive T cells \\
Chemotherapy & "Immunologic" tumor cell death \\
& $\begin{array}{l}\text { Alterations in tumor cell phenotype } \\
\text { Enriched effector:regulator cell ratios }\end{array}$ \\
Radiation & Alteration in tumor cell phenotype \\
\hline Imids ${ }^{\dagger}$ (lenalidomide) & Alterations in tumor cell phenotype \\
\hline
\end{tabular}

*ADCC, antibody-dependent cell-mediated cytotoxicity.

$\dagger$ Imids are a novel class of immunomodulators. 